\title{
TÃO PRÓXIMOS, TÃO DISTANTES: \\ a Justiça Restaurativa entre comunidade e sociedade
}

\author{
Dissertação de Mestrado
}

Professora Orientadora Janaina Conceição Paschoal

Faculdade de Direito da Universidade de São Paulo

São Paulo

2009 


\author{
Juliana Cardoso Benedetti
}

\title{
TÃO PRÓXIMOS, TÃO DISTANTES: a Justiça Restaurativa entre comunidade e sociedade
}

Dissertação apresentada como requisito parcial para a obtenção do título de Mestrado junto ao Departamento de Direito Penal, Medicina Forense e Criminologia da Faculdade de Direito da Universidade de São Paulo.

Professora Orientadora: Janaina Conceição Paschoal

São Paulo 
Juliana Cardoso Benedetti

TÃO PRÓXIMOS, TÃO DISTANTES:

A Justiça Restaurativa entre comunidade e sociedade

Professora Orientadora Janaina Conceição Paschoal 


\section{Agradecimentos}

Agradeço à minha professora orientadora Janaina Conceição Paschoal, aos professores Ana Elisa Bechara e José Eduardo Faria - pelos comentários realizados quando de minha banca de qualificação -, aos professores Maíra Rocha Machado, Leonardo Sica e Sérgio Salomão Shecaira - por acompanharem minha trajetória acadêmica - e aos professores Roberto Bergalli, Iñaki Rivera Beiras, Héctor Silveira Gorski, Julio Zino Torrazza e Gabriela Rodriguez Fernandez - pelo diálogo travado na Espanha. Também à equipe do Ilanud - em especial, Karyna Batista Sposato, Paula Miraglia, Aline Yamamoto, Mariana Raupp, Fernanda Emy Matsuda, Davi Tangerino e Alessandra Florencio - e à equipe do Projeto-Piloto de Justiça Restaurativa do Núcleo Bandeirante - em especial, Lianne Carvalho, Simone Republicano e o juiz Asiel Henrique de Sousa. A presente dissertação, sem dúvida, não teria sido possível sem a apreciada colaboração dessas pessoas. 
A meus pais.

Ao André. 


\section{RESUMO}

A presente dissertação analisa o papel da Justiça Restaurativa na atualidade, tratando de situar o seu lugar no debate sociológico, inaugurado por Ferdinand Tönnies, que identifica na "comunidade" e na "sociedade" duas formas de sociabilidade distintas. A hipótese de que partimos é a de que, a despeito de ser celebrada como uma panacéia para os males do sistema de justiça criminal tradicional, a Justiça Restaurativa, por evocar um ideal de comunidade de difícil materialização nos dias de hoje, talvez não seja apropriada no contexto das sociedades modernas. Para verificá-la, empreendemos uma revisão da literatura que examina as características e as conseqüências sociais do processo de modernização, com foco nas obras de Anthony Giddens e Zygmunt Bauman. A partir delas, oferecemos um diagnóstico que retrata como a transição de uma modernidade simples para uma modernidade reflexiva acirrou, nas últimas décadas, a sensação de insegurança e transformou o ideal comunitário, que anima a Justiça Restaurativa, em um refúgio para a inconstância da vida moderna. A seguir, descrevemos o desenvolvimento teórico e prático da Justiça Restaurativa e, com o fim de verificar nossa hipótese empiricamente, realizamos um estudo de caso, examinando em profundidade dois conflitos encaminhados ao Programa-Piloto de Justiça Restaurativa dos Juizados Especiais Criminais do Núcleo Bandeirante, localizado nos arredores de Brasília, no Distrito Federal. Concluímos, enfim, que a Justiça Restaurativa, por mobilizar emoções íntimas, funciona bem quando aplicada a conflitos penais protagonizados por pessoas próximas, vinculadas por laços de tipo comunitário. No entanto, quando se trata de conflitos envolvendo estranhos, típicos da modernidade, a estratégia restaurativa tende a ser mal-sucedida. Portanto, do mesmo modo que, no presente, a comunidade é incapaz de substituir a sociedade, uma Justiça Restaurativa atrelada a ideais comunitários não será capaz de alterar significativamente o esquema de funcionamento de um sistema de justiça criminal criado de acordo com as particularidades das sociedades modernas.

Palavras-chave: Justiça Restaurativa; justiça criminal; justiça comunitária; modernidade reflexiva; formas alternativas de solução de conflitos penais. 


\section{ABSTRACT}

This dissertation analyzes the role of Restorative Justice in the present, attempting to place it in the sociological debate launched by Ferdinand Tönnies, who identifies in "community" and "society" two different forms of sociability. The hypothesis from which we depart is that, although celebrated as a panacea to the problems of the traditional criminal justice system, perhaps Restorative Justice is not appropriate under the context of modern societies, since it evokes an ideal of community that could hardly be materialized nowadays. In order to verify this hypothesis, we undertake a review of the literature that examines the characteristics and the social consequences of the modernization process, focusing on the works of Anthony Giddens and Zygmunt Bauman. Based upon such accounts, we offer a diagnosis that depicts how the transition from a simple modernity toward a reflexive modernity intensified, in the last decades, the perception of insecurity and transformed the communitarian ideal, which underpins Restorative Justice, into a shelter from the inconstancy of modern life. Then, we describe the theoretical and practical development of Restorative Justice and, in order to empirically verify our hypothesis, we conduct a case study, perusing two conflicts submitted to the Pilot Program of Restorative Justice promoted by the Minor Offences Court of Núcleo Bandeirante, located in the surroundings of Brasilia, in the Federal District. Finally, we conclude that, for mobilizing intimate emotions, Restorative Justice works well when applied to criminal conflicts whose protagonists are closely-related persons, linked by communitarian bounds. However, when it comes to conflicts involving strangers, typical of modernity, the restorative strategy is likely to fail. Therefore, in the same way that community is unable to replace society in the present, a Restorative Justice dependent on communitarian ideals will not be capable of significantly altering the performance of a criminal justice system created according to the particularities of modern societies.

Key words: Restorative Justice; criminal justice; community justice; reflexive modernity; alternative criminal dispute resolution. 
Pode alguém amar a todos, a todos os homens, a todos os seus vizinhos? Eu me pergunto frequentemente essa questão. É claro que não. É antinatural, realmente. No amor abstrato pela humanidade uma pessoa quase sempre não ama ninguém senão a si mesmo.

Fiódor Dostoiévski, O idiota. 


\section{Sumário}

$\begin{array}{ll}\text { Introdução } & 03\end{array}$

1. Comunidade e sociedade 05

1.1. As noções de comunidade e sociedade no debate sociológico 05

1.2. Características da modernidade reflexiva e o retorno da comunidade 15

$\begin{array}{ll}\text { 1.2.1. Referencialidade interna da vida } & 15\end{array}$

1.2.2. Distanciamento do tempo e do espaço 29

1.2.3. A comunidade como refúgio contra a insegurança da modernidade 35 reflexiva

\section{A Justiça Restaurativa em ação}

2.1. Origem e formulação da Justiça Restaurativa

2.1.1. Desenvolvimento prático e marco normativo internacional

2.1.2. Perspectivas teóricas e a noção de comunidade

2.2. Desenvolvimento da Justiça Restaurativa no Brasil

2.3. Estudo de caso: o Projeto-Piloto de Justiça Restaurativa dos Juizados Especiais Criminais do Núcleo Bandeirante-DF 
2.3.6. Casos

3.1. Brechas para a comunidade

3.2. Investidas da sociedade

Conclusão

Bibliografia

Anexos 


\section{Introdução}

Ao examinar o cenário cultural brasileiro do século XIX, o crítico literário Roberto Schwarz (SCHWARZ, 1977) argumentou que as noções liberais, importadas do contexto europeu e norte-americano, figuravam, no Brasil, como "ideias fora do lugar". Embora a cultura brasileira se tenha encarregado, à sua maneira, de acomodar ideias liberais no ninho de práticas marcadamente antiliberais, as aspirações evocadas pelo discurso liberal soavam como notas dissonantes aos ouvidos brasileiros, mais familiarizados com a ladainha anacrônica da escravidão e do clientelismo.

A sensação de estranheza que Schwarz sublinha na sua análise do lugar do liberalismo na realidade cultural brasileira oitocentista também acomete aqueles que tratam de examinar o lugar da Justiça Restaurativa nas sociedades contemporâneas. Com efeito, sob certos aspectos, a Justiça Restaurativa, tal qual o liberalismo no Brasil do século XIX, parece ser, no contexto atual, uma "ideia fora do lugar", que destoa do quadro geral em que está inserida. O objetivo do presente trabalho é, precisamente, demonstrar que o ideal restaurativo, nos moldes em que é proposto e defendido pelos principais formuladores e gestores da Justiça Restaurativa, não se ajusta indistintamente a todos os cenários existentes nas sociedades contemporâneas e que, portanto, não pode ser encarado, como muitas vezes tem sido, como uma panaceia para as mazelas do sistema de justiça criminal.

Parte-se da ideia, presente nas mais diversas correntes do pensamento social, de que o advento da modernidade trouxe consigo formas inéditas de sociabilidade, diferentes daquelas que estruturavam as sociedades ditas tradicionais. Em outras palavras, supõe-se que nas sociedades modernas vigora um padrão de relação social distinto daquele que predominava nas sociedades tradicionais. No repertório da teoria social, a diferença entre esses dois padrões de sociabilidade é expresso pela oposição entre comunidade e sociedade, formulada por Ferdinand Tönnies (TÖNNIES, 1995 [1887]). A Justiça Restaurativa, ao introduzir a comunidade como uma variável significativa no fazer justiça, alude a um tipo de sociabilidade cada vez mais rarefeito no seio das sociedades modernas e tende, assim, a ser realmente uma "ideia fora do lugar", inócua quando o conflito em questão se afirma sobre uma relação social afeita, nos termos de Tönnies, ao modelo da sociedade e não ao da comunidade. Do mesmo modo em que Michel Foucault analisa criticamente, na sua clássica obra Vigiar e Punir (FOUCAULT, 2002 [1975]), o processo 
pelo qual a prisão se tornou, ao longo da história, uma resposta penal polivalente, aplicável a toda e qualquer espécie de delito, cabe-nos, no presente trabalho, questionar se a Justiça Restaurativa, tal como ela é proposta por seus principais idealizadores e efetivada pela maioria de seus operadores, deve seguir o mesmo caminho e se generalizar como reação adequada a todo e qualquer tipo de conflito. Assumindo como fio condutor a distinção conceitual existente entre comunidade e sociedade, o trabalho aponta para uma resposta negativa a essa questão.

A fim de construir esse argumento, é preciso expor o significado os termos-chave que conduzem o trabalho: comunidade e sociedade. Para isso, recorremos, além de Tönnies e do debate entre ele e Émile Durkheim, a cientistas sociais preocupados em abordar as características peculiares da modernidade e, mais especialmente, da chamada modernidade reflexiva ou tardia. Como se verá, é o aprofundamento do processo de individualização trazido pela modernidade reflexiva que cria as condições das quais ressurge a noção de comunidade. Depois, é necessário analisar como a Justiça Restaurativa mobiliza, na teoria e na prática, a noção de comunidade, recuperando suas origens e fundamentos, mundial e localmente. Um estudo de caso, tendo como objeto um projeto-piloto de Justiça Restaurativa situado no Distrito Federal, servirá para elucidar de que forma atua o ideal restaurativo em diferentes espécies de conflitos, envolvendo distintas formas de relacionamento social. 


\section{Comunidade e Sociedade}

\subsection{As noções de comunidade e sociedade no debate sociológico}

Cada disciplina desenvolve uma linguagem própria. Para descrever os fenômenos que tem por objeto, é obrigada a se apropriar de termos de uso corrente. Ao fazê-lo, no entanto, inocula nesses termos a própria descrição que realiza. As palavras apropriadas pela disciplina, por assim dizer, passam a condensar em si mesmas o próprio argumento que se estrutura a partir do uso delas. Esse dispositivo através do qual se "colam" descrições a determinados termos evita que a cada novo passo adiante, no desenvolvimento da disciplina, seja necessário retroceder a explicações que já foram feitas. Tais termos passam a funcionar, assim, como uma espécie de "atalho": toda vez que a disciplina quer aludir a um fenômeno, não precisa descrevê-lo outra vez - basta remeter ao termo utilizado anteriormente na sua descrição. Esse é processo pelo qual uma disciplina constrói o seu repertório terminológico: cada novo termo apropriado passa a evocar uma série de descrições, argumentos e encadeamentos próprios da disciplina, com o que se distancia do seu sentido vulgar e adquire um caráter marcadamente técnico.

Com sua obra Comunidade e Sociedade, publicada originalmente em 1887, o sociólogo Ferdinand Tönnies adicionou dois novos termos - precisamente, os que figuram no título do livro - ao repertório da teoria social. Cada um desses termos encerra um mundo tão rico que a sua própria tradução do alemão já implicaria, para alguns, uma perda de sentido, em razão de as palavras comunidade e sociedade não possuírem a mesma expressividade que as originais Gemeinschaft e Gesellschaft. Comunidade e sociedade são "conceitos-tipo", que se situam na intersecção entre as duas vertentes epistemológicas em que Tönnies divide a sociologia: a sociologia pura, de teor eminentemente teórico, cuja finalidade é a construção de conceitos, e a sociologia aplicada, de cunho histórico, que trabalha com elementos empíricos. Os conceitos-tipo comunidade e sociedade são construídos sobre bases recolhidas da história, mas não se arrogam como retratos fiéis de formações sociais concretas. São, na verdade, a exemplo do "tipo ideal” weberiano, modelos abstratos, que não se encontram em suas formas puras na realidade, mas que dispõem, não obstante, de potencial heurístico para uma compreensão global das tendências históricas. Na sociologia pura, os conceitos são estáticos, fixos; na sociologia 
aplicada, são dinâmicos, dispostos em uma progressão temporal em que a sociedade avança sobre a comunidade (CAHNMAN, 1995). O conceito-tipo apresenta um caráter “trans-histórico”, isto é, “ tem por meta transcender o empírico para reaplicar-se na própria análise da história", e "relacional", já que as duas noções que expressa - comunidade e sociedade - só são inteligíveis uma em relação à outra (MIRANDA, 1995a, p. 64).

O contraste entre comunidade e sociedade formulado por Tönnies é dado pela dicotomia orgânico-mecânico. A comunidade é comparada a um organismo vivo, ao passo que a sociedade é descrita como uma construção mecânica (TÖNNIES, 1995 [1887]). Como em um organismo, a comunidade conforma um todo em que as partes integram-se harmoniosamente, de forma natural e espontânea, de modo a criar uma unidade que tem uma individualidade não redutível à mera soma das partes. Em um agrupamento social que se caracterize como uma comunidade, o que promove esse tipo de ligação orgânica é o fato de seus membros partilharem uma vida em comum. Três formas de relacionamento supõem a comunhão de vida que define a comunidade: o parentesco, por conta dos vínculos biológicos; a vizinhança, por conta da contiguidade física entre as habitações; e, enfim, a amizade, por conta da afinidade que emerge de atividades e sentimentos comuns. A comunidade se funda no que Tönnies chama de consenso - um entendimento tácito existente entre as pessoas, uma forma de acordo silencioso e não refletido. A sociedade, por sua vez, é por ele descrita como um agregado artificial, cujos membros estão meramente justapostos, como peças de uma engrenagem que funcionam de modo independente, com o que o todo se resume à mera soma de partes perfeitamente distinguíveis. $\mathrm{O}$ contato entre as partes se traduz em relações de troca, em que cada uma delas é motivada essencialmente pelo próprio interesse, havendo uma tendência significativa de competição entre elas e de dissimulação sob a forma de uma aparente polidez ou cortesia. Se o espaço privilegiado para o florescimento da comunidade é a aldeia, o da sociedade é, sem dúvida, a metrópole.

Para Tönnies, o fundamento de toda ação humana radica na vontade humana. Centrando-se nos processos mentais que se desenrolam no nível do psiquismo individual, identifica dois tipos de vontade, os quais correlaciona a cada um dos seus conceitos-tipo de agrupamentos sociais. Assim, a chamada Wesenwille (vontade natural ou essencial) corresponde à comunidade, enquanto a Kürwille (vontade artificial ou reflexa) corresponde à sociedade (TÖNNIES, 1995 [1887]). Ambas se diferenciam quanto à forma em que 
estruturam os encadeamentos mentais - na Wesenwille, o pensamento está contido na vontade, isto é, é um desdobramento natural e espontâneo dela; na Kürwille, ao contrário, é o pensamento que abrange a vontade, tendo precedência sobre ela e orientando a sua direção. As formas características da Wesenwille, derivadas, respectivamente, de componentes vegetativos, animais e mentais, são o prazer, o hábito e a memória. As formas da Kürwille, por sua vez, são a reflexão, a conveniência e o conceito. Na verdade, o que melhor distingue a Kürwille da Wesenwille é a cisão que ela promove entre meios e fins (CAHNMAN, 1995); se a Kürwille opera, justamente, através do cálculo racional de adequação de meios e fins, subordinando, pelo pensamento, a vontade que orienta a ação meio à vontade que orienta a ação fim, esse tipo de consideração é totalmente alheio à Wesenwille, já que meios e fins encontram-se amalgamados em uma única e indivisível manifestação de pensamento e vontade.

De acordo com Tönnies, "Enquanto, na comunidade, os homens permanecem essencialmente unidos, a despeito de tudo o que os separa, na sociedade eles estão essencialmente separados, apesar de tudo que os une" (TÖNNIES, 1995 [1887], p. 252). Em outras palavras, se na comunidade se verifica uma tendência centrípeta, uma vez que a comunhão de vida e o consenso que sobre ela se erige corroboram com a coesão social, a sociedade é atravessada por um vetor em sentido inverso, de caráter centrífugo, já que nela o cálculo de meios e fins que subjaz à busca da satisfação de interesses particulares e dá forma a uma mentalidade marcadamente individualista pulveriza a unidade que caracteriza a comunidade. Por esse motivo, Tönnies visualiza na sociedade, em tom pessimista, uma forte tendência de desagregação, a qual só é contida graças ao Estado, descrito por ele como uma construção artificial que se sobrepõe às formas naturais de sociabilidade típicas da comunidade. Em Tönnies, a comunidade é vista como uma forma superior de sociabilidade, uma vez que favorece a construção, pelos homens, de identidades concretas, perfeitamente enraizadas no meio social, em oposição às identidades abstratas, desprovidas de uma base social, existentes na sociedade. A comunidade propicia, assim, mais que a sociedade, uma visão de totalidade entre o ser individual e o ser social. (MIRANDA, 1995a).

Assim, comunidade e sociedade, Gemeinschaft e Gesellschaft, são termos singelos que, a partir do trabalho de Tönnies, passam a evocar noções bastante complexas. Cada uma delas remete à descrição de formas de sociabilidade que, embora sempre tenham 
convivido em alguma medida, tornam-se mais ou menos proeminentes conforme o momento histórico. As descrições condensadas nesses termos são retomadas por outro sociólogo, Émile Durkheim, na sua obra Da divisão do trabalho social, publicada em 1893, mas com sinais trocados. Em 1889, Durkheim publicou na Revue Philosphique uma resenha da obra de Tönnies na qual criticou a caracterização da sociedade como um mero agregado mecânico de indivíduos. Nessa resenha, Durkheim já enuncia, ainda que brevemente, a ideia que desenvolverá melhor no livro Da divisão do trabalho social, de que também nas sociedades contemporâneas existe uma vida coletiva que não se reduz ao conjunto fragmentário das vidas individuais de seus membros. De acordo com Durkheim, Tönnies é incapaz de perceber em que consiste a vida coletiva das sociedades modernas porque sua análise da Gesellschaft se apoia em um método "completamente ideológico", de caráter dedutivo, quando o mais apropriado seria valer-se de um raciocínio indutivo, desvendando a estrutura da Gesellschaft através das pistas fornecidas por suas leis e costumes (DURKHEIM, 1995 [1889], p. 118). Na resenha, Durkheim dá a entender que haveria uma certa continuidade de desenvolvimento entre Gemeinschaft e Gesellschaft, de modo que a natureza dos vínculos sociais existentes em cada uma delas não poderia se modificar, completamente, de um tipo orgânico para um tipo mecânico e que, portanto, existiria na Gesellschaft uma vida coletiva tão orgânica, isto é, tão natural e espontaneamente harmoniosa, quanto aquela da Gemeinshaft. Na obra Da divisão social do trabalho, no entanto, Durkheim abandona a hipótese da continuidade e retoma a dicotomia orgânico-mecânico, invertendo-a: a comunidade é entendida como um agrupamento social mecânico, enquanto a sociedade é considerada um agrupamento orgânico.

Durkheim arranca do diagnóstico de que, no senso comum, o fenômeno da divisão do trabalho social é avaliado negativamente, sendo apontado como responsável, em virtude da extrema especialização que supõe, por uma sobrevalorização do indivíduo às custas do embotamento de valores coletivos e, portanto, reputada como uma ameaça à integridade social. O objetivo de Durkheim é, precisamente, desmistificar essa ideia, provando que a divisão do trabalho, ao contrário do que se crê, exerce uma importante função moral nas sociedades contemporâneas, promovendo não a sua desintegração, mas a sua coesão. De acordo com Durkheim, da divisão do trabalho social emerge um novo tipo de solidariedade social, isto é, uma nova forma de coesão social entre as pessoas, que ele parece, aliás, ver com melhores olhos do que aquele tipo de solidariedade próprio à comunidade. Diante da 
dificuldade prática de analisar um fenômeno essencialmente moral, como a solidariedade, Durkheim, coerente com a observação feita na resenha da obra de Tönnies a respeito da superioridade dos métodos indutivos, trata de examinar a solidariedade através do direito. O direito é compreendido, nesse sentido, como a expressão institucionalizada da solidariedade social e, portanto, pode dizer algo a respeito dela.

Durkheim identifica dois tipos de direito, a partir da espécie de sanção que corresponde a cada um deles: o direito repressivo, fundado na punição, e o direito restitutivo, calcado na reparação. $\mathrm{O}$ direito repressivo compreende o direito penal, ao passo que o direito restitutivo se refere, em geral, ao direito civil, ao direito comercial, ao direito processual, ao direito administrativo e ao direito constitucional (DURKHEIM, 1999 [1893]). Ao analisar o direito repressivo, Durkheim conclui que crime consiste em uma ofensa a sentimentos fortemente arraigados nos membros do grupo social. Os sentimentos cuja vulneração ensejam a caracterização de um ato como criminoso são o núcleo do que Durkheim chama de "consciência coletiva", definindo-a como "o conjunto das crenças e dos sentimentos comuns à média dos membros de uma mesma sociedade", que "forma um sistema determinado que tem vida própria” (ibid., p. 50). Dessa forma, o direito repressivo evidencia uma forma de solidariedade que se funda na participação do indivíduo na consciência coletiva da sociedade a que pertence ou, por assim dizer, "na conformidade de todas as consciências particulares a um tipo comum que não é outro senão o tipo psíquico da sociedade" (ibid., p. 78). Por assim dizer, junto de nossa consciência individual, que contempla estados psíquicos exclusivamente pessoais, vive em nós, segundo Durkheim, uma consciência coletiva, na qual se concentram estados comuns a toda a sociedade. É essa consciência coletiva que forja a solidariedade social e garante, assim, a coesão da sociedade. Essa espécie de solidariedade é tanto mais forte quanto maior o espaço ocupado, na vida psíquica dos integrantes do grupo social, pela consciência coletiva, em detrimento, é claro, do espaço ocupado pela consciência individual. Cuida-se, então, de uma sociedade de indivíduos semelhantes, já que o espaço reservado às particularidades é bastante estreito. Enfim, o indivíduo é solidário em relação aos demais, essencialmente, porque é deles semelhante.

O direito restitutivo, por sua vez, tem duas formas, segundo Durkheim: uma negativa, que impõe deveres de abstenção, e outra positiva, que estabelece direitos e deveres de cooperação. A forma negativa é típica dos direitos reais, que unem uma pessoa 
a uma coisa. O titular do direito real é amparado evitando-se, através da imposição de um dever de abstenção geral a terceiros, que os demais possam ingerir sobre a coisa. Essa forma negativa, no entanto, só seria capaz de engendrar uma solidariedade também negativa, eis que não faz com que as vontades convirjam, mas tão-somente evita um choque entre elas. Os demais ramos do direito restitutivo, incluindo-se o direito contratual, o direito familiar e o direito administrativo, por sua vez, constituem sua forma positiva e prestam-se, exatamente, a criar condições de cooperação entre os indivíduos. Sua tarefa é distribuir papéis e promover uma repartição harmônica de funções entre os membros da sociedade, em um contexto de divisão do trabalho social. De acordo com Durkheim, o adensamento físico e moral das formações sociais, decorrente do aumento da concentração populacional e dos contatos que ela implica, debilita a consciência coletiva e permite que a consciência individual ganhe espaço na vida psíquica dos membros da sociedade às custas dela. Isso viabiliza o cultivo de gostos e habilidades pessoais, potencializando as diferenças entre os indivíduos, que tendem, assim, a se especializarem em atividades distintas. À medida que a crescente especialização os obriga a manter contatos constantes com os demais para prover os meios da sua própria subsistência, a divisão do trabalho cria uma situação de dependência recíproca entre os indivíduos e, de modo análogo à consciência coletiva, também contribui para a coesão social. O vetor da solidariedade, nesse caso, não é a semelhança, mas a diferença, que forja a criação de um vínculo de dependência. $O$ indivíduo é solidário em relação aos demais não porque com eles se pareça, mas porque deles depende.

Nesse sentido, se a consciência coletiva está associada a uma forma de solidariedade cuja manifestação é o direito repressivo, o fenômeno da divisão do trabalho social está relacionado a uma forma de solidariedade que tem expressão no direito restitutivo. Nas palavras de Durkheim:

A vida social deriva de uma dupla fonte: a similitude das consciências e a divisão do trabalho social. O indivíduo é socializado, no primeiro caso, porque, não tendo individualidade própria, confunde-se, como seus semelhantes, no seio de um mesmo tipo coletivo; no segundo, porque, tendo uma fisionomia e uma atividade pessoais que o distinguem dos outros, depende deles na mesma medida em que se distingue e, por conseguinte, da sociedade que resulta de sua união" (DURKHEIM, 1999 [1893], p. 216). 
Trata-se, então, de duas formas de solidariedade distintas: uma solidariedade mecânica e uma solidariedade orgânica. Durkheim nomeia de mecânica a solidariedade materializada pelo direito repressivo, por comparar os indivíduos que dela tomam parte a moléculas de um corpo inorgânico, que se encontram coesas simplesmente pela similitude e pela justaposição e movem-se juntas, na mesma direção, por conta de uma força meramente mecânica. Analogamente, numa sociedade cuja solidariedade é mecânica, as consciências individuais tendem a seguir inercialmente o movimento da consciência coletiva (ibid., p. 107). Diferentemente, a solidariedade expressa pelo direito restitutivo é por ele denominada de orgânica, na medida em que se comparam os indivíduos unidos por essa forma de solidariedade aos órgãos de um corpo vivo, que são diferentes uns em relação aos outros, exercem autonomamente suas respectivas funções e mantêm-se coesos pela dependência recíproca que possuem. Historicamente, a solidariedade orgânica tende a substituir a solidariedade mecânica, o que se evidencia pelo fato de que, nas sociedades modernas, disposições jurídicas de natureza restitutiva superam em volume aquelas de índole repressiva, ao passo que em formações sociais anteriores o direito tinha um teor quase inteiramente repressivo.

A divisão do trabalho social, no entanto, nem sempre é capaz de garantir a coesão social. De acordo com Durkheim, demora algum tempo até que uma perfeita acomodação entre as distintas funções desempenhadas pelos vários órgãos que compõem a sociedade seja obtida. Esse arranjo só é alcançado quando surge alguma forma de regulamentação, na figura de costumes e normas que vão se moldando de maneira espontânea a partir do contato prolongado entre os diferentes órgãos, os quais vão paulatinamente, assim, se ajustando uns aos outros. Enquanto essa regulamentação não ganha forma, diz Durkheim, a divisão do trabalho é anômica - a anomia é, portanto, um estado em que a regulamentação social é ausente ou insuficiente para assegurar a coesão social. Trata-se, porém, de um estado transitório, que tende a ser superado com a passagem do tempo.

Uma vez confrontadas as posições de Tönnies e de Durkheim, o que parece, à primeira vista, ser apenas um debate inócuo sobre o melhor adjetivo - mecânico ou orgânico - para se qualificar a sociedade moderna, revela, depois de um exame mais cuidadoso, ser muito mais do que isso. É preciso ler o subtexto por trás dessas noções. Caracterizar uma sociedade como orgânica ou mecânica significa tomar uma posição a respeito da questão, muito cara a ambos os autores, da coesão social. Ao qualificar a 
sociedade de mecânica, Tönnies quer dizer que não há nada nela que garanta a sua integridade. A dinâmica da sociedade, cujo motor é o individualismo que emana da Kürwille, a reduz a uma mera justaposição de indivíduos, não havendo nenhuma força social - à exceção, talvez, do Estado, que, no entanto, dispõe unicamente da ferramenta da coerção, já que, por ser uma construção artificial, é incapaz de gerar o consenso natural à comunidade - que impeça a sua desagregação. Durkheim, ao contrário, ao conceber a sociedade moderna como um corpo orgânico, insistindo que a divisão do trabalho social, como demonstra a prevalência do direito restitutivo sobre o direito repressivo, inaugura uma nova forma de solidariedade entre os indivíduos, fundada na dependência recíproca, se esforça para provar que a sociedade conta, sim, com forças que garantem a sua coesão. No prefácio à segunda edição de sua obra, Durkheim conclama pela reorganização das corporações profissionais como resposta à situação de anomia - atribuída às "desordens do mundo econômico" - que testemunhava na época. Durkheim acreditava que o recuo das funções morais da sociedade diante das funções econômicas exigia a iniciativa de um ente, que enxergava na corporação, capaz de encabeçar a formulação de nova regulamentação social e forjar, assim, uma nova moralidade. Mas, em nenhum momento, Durkheim deixou de considerar a anomia como uma situação que seria superada após o amadurecimento das sociedades modernas. Tanto Durkheim como Tönnies, portanto, pressupõem que a coesão depende da existência de uma instância superior aos indivíduos, que tem uma vida própria, independente deles, e se impõe sobre eles - seja o consenso, seja a consciência coletiva ou a divisão do trabalho -, mas Durkheim a vislumbra na sociedade moderna e Tönnies não.

Essa diferença leva a outra implicação das posições de Tönnies e Durkheim. A divergência entre ambos pode ser interpretada como um certo pessimismo de Tönnies, contraposto a um otimismo de Durkheim, no que toca à sociedade moderna. Se Tönnies acredita que a sociedade, por fraturar a relação de totalidade, existente na comunidade, entre o ser individual e o ser social, inviabiliza a plena realização da identidade humana, Durkheim crê que é justamente o enfraquecimento da consciência coletiva, promovido pela sociedade, que permite o florescimento das consciências individuais e estimula, assim, o desenvolvimento das potencialidades do indivíduo. Assim, em termos das possibilidades que traz à autorrealização pessoal, um vê a sociedade como um cenário desastroso e o outro como um terreno fértil. 
As ciências sociais, em seu desenvolvimento ulterior, ficaram ao lado de Durkheim. Enquanto Durkheim foi coroado como um dos pais fundadores da sociologia, ganhando destaque como um "clássico", Tönnies, depois de passar à história como um "romântico" que lamentava a perda da comunidade, ou como um irracionalista nostálgico de tempos passados $^{1}$, praticamente caiu no esquecimento. Na verdade, a visão de Durkheim era muito mais atraente que a de Tönnies porque encontrava eco no projeto de emancipação iluminista, que pretendia libertar o indivíduo dos grilhões que as formas tradicionais de vida, especialmente aquelas circunscritas à família, à aldeia e ao estamento, lhe impunham, restringindo o seu campo de ação. Hoje, no entanto, parece que alguns ouvidos já não se fazem mais de surdos à preocupação de Tönnies e a "nostalgia" da comunidade é revivificada em alguns discursos e em algumas práticas.

Sociedade e comunidade integram um processo dialético que ainda não encontrou a sua síntese. Nesse sentido, o ressurgimento da comunidade pode ser entendido como uma reação ao avanço da sociedade. Nossa hipótese é que a popularização da Justiça Restaurativa está relacionada com a tendência atual de reaparecimento da comunidade. No entanto, da mesma forma que o resgate da comunidade tem como limite a indubitável primazia da sociedade na realidade contemporânea, também a Justiça Restaurativa possui limitações quando lida com conflitos que envolvem relações típicas da Gesellschaft e não da Gemeinschaft. Para compreendermos tais restrições, no entanto, é preciso entender as modificações trazidas pela transição da comunidade à sociedade, processo que é geralmente denominado de destradicionalização ou, o que é o mesmo, modernização.

Ulrich Beck afirma que a chamada modernização diz respeito a processos que revolucionaram os mais variados âmbitos da vida social, desde a organização da produção e do trabalho até a configuração do exercício do poder político, passando pelas formas de relacionamento pessoal e pelas chaves de conhecimento do mundo e de concepção da realidade (BECK, 2006). Anthony Giddens, por sua vez, enfatiza o que chama de “descontinuidades da modernidade", querendo dizer, com essa ideia, que "Os modos de vida produzidos pela modernidade nos desvencilharam de todos os tipos tradicionais de ordem social, de uma maneira que não tem precedentes" (GIDDENS, 1991, p. 14). A

\footnotetext{
${ }^{1}$ Ver, por exemplo, a feroz crítica de Georg Lukács, que acusa Tönnies de ser um "anticapitalista romântico", que deforma a interpretação marxiana da realidade "através de um prisma subjetivistairracionalista" (LUKÁCS, 1995, p. 138). Para uma bem fundamentada refutação da crítica de Lukács, que ressalta as convergências existentes entre a teoria de Marx e a de Tönnies, cf. o artigo de Orlando de Miranda (MIRANDA, 1995b).
} 
mudança, de acordo com Giddens, foi dramática por conta de seu ritmo acelerado, de seu escopo global e do caráter inédito de algumas das instituições - ele cita como exemplo o Estado-nação - que trouxe em seu bojo.

De acordo com Giddens, "tradição é repetição" (GIDDENS, 1997, p. 85). Com efeito, toda tradição é composta de certos rituais, isto é, de determinadas fórmulas de comportamento que são reiteradamente postas em marcha no curso da vida social. É através da repetição dessas fórmulas que a tradição atua como um "meio organizador da memória coletiva" de um dado grupo social. Essa tarefa estruturante da tradição se exerce de duas maneiras: por meio do gerenciamento do tempo e do espaço e da fixação de referências externas para a conduta individual. A repetição estabelece um vínculo entre passado, presente e futuro, à medida que práticas sociais do passado moldam o presente e se projetam, também, sobre o futuro, conferindo à experiência do tempo um senso de continuidade. Tais práticas têm lugar sobre uma base geográfica determinada e, portanto, também se prestam a circunscrever a experiência do espaço a limites físicos bem definidos. Com a passagem do tempo e a fixação em um espaço, essas práticas adquirem um conteúdo normativo, à medida que representam não só “o que 'é' feito em uma sociedade, mas o que 'deve ser' feito" (ibid., p. 84), tornando-se referências externas aos indivíduos a partir das quais eles norteiam as próprias condutas.

Nesse sentido, o processo de destradicionalização - ou de modernização - que caracteriza a transição das sociedades tradicionais às sociedades modernas implica necessariamente uma mudança tanto na forma pela qual o tempo e o espaço são gerenciados quanto na determinação de referências externas à conduta individual. É sob esse duplo aspecto que a modernização será analisada aqui. A teoria sociológica que vem se ocupando de fazer um diagnóstico da modernidade - a zeitdiagnostische Soziologie, nas palavras de Scott Lash (LASH, 1997, p. 144) ${ }^{2}$ - afirma que a modernização significou, de um lado, o surgimento da referencialidade interna da vida, às custas do embotamento dos referenciais externos a partir dos quais o indivíduo guiava sua conduta, e, de outro, um distanciamento do espaço-tempo vivenciado na experiência cotidiana.

\footnotetext{
${ }^{2}$ De acordo com Sérgio Costa, a Zeitdiagnose se refere ao "tratamento de problemas específicos em uma época determinada, sem a pretensão do estabelecimento de postulados gerais e partindo-se de evidências que não decorrem necessariamente da investigação empírica, segundo os métodos científicos" (COSTA, 2006, p. 2).
} 


\subsection{Características da modernidade reflexiva e o retorno da comunidade}

\subsubsection{Referencialidade interna da vida}

Uma das faces mais importantes do processo de modernização é o que se convencionou chamar de individualização. O processo de individualização, de acordo com Beck, se desenrola em três níveis. O primeiro consiste no que ele chama de dimensão de liberação, aludindo à dissolução das redes de dependência econômica e dominação política fundadas em formas tradicionais de vida, amparadas especialmente em vínculos familiares ou comunitários (BECK, 2006). Essa dimensão corresponde ao processo em que a subsistência do indivíduo, uma vez que ele é descolado de sua rede social, passa a depender exclusivamente da venda de sua força de trabalho no mercado, a partir da qual aufere os proventos com que pode obter quaisquer outros bens, também via mercado. De fato, conforme Beck, "individualización significa dependencia del mercado en todos los aspectos de la vida" (ibid., p. 216). A dependência direta entre os seres humanos, que caracterizava formas de vida tradicionais, é substituída por uma forma indireta, mais opaca, de dependência mediada pelo mercado, que prescinde do estabelecimento de vínculos sociais de caráter pessoal ou de proximidade entre os indivíduos. É por isso que Zygmunt Bauman afirma que o homo oeconomicus, produto da sociedade de mercado, é um homem sem vínculos sociais (BAUMAN, 2004). Tornando-se o artífice da própria sobrevivência - já que não tem mais com quem contar além de si mesmo para provê-la, o indivíduo converte-se "en la unidad de reproducción de lo social” (BECK, 2006, p. 213): a sociedade já não é mais composta de famílias, clãs, segmentos, tribos ou comunidades - é composta simplesmente de indivíduos.

Algumas análises destacam, ao lado do mercado, também o papel do Estado nessa "dimensão de liberação" do processo de individualização. Bauman, por exemplo, afirma que o Estado moderno "incumbiu-se de desmantelar os pouvoirs intermédiaires, ou seja, as formas de autonomia local, de autoafirmação e de autogoverno" (BAUMAN, 2004, p. 92). Algo semelhante diz, de modo mais detido, Pierre Rosanvallon. Sua preocupação é compreender a chamada crise do Estado providência e, para isso, seu primeiro passo é analisar a natureza do Estado providência. Sua tese é a de que o Estado providência que se consolidou no século XX consiste em um aprofundamento e em uma expansão do Estado 
protetor clássico (ROSANVALLON, 1995). Lembrando Locke e especialmente Hobbes, para quem a razão de ser do Estado é a garantia da segurança individual, Rosanvallon nota que o Estado-nação moderno surge como um Estado protetor. A natureza desse Estado protetor se funda em uma relação de determinação recíproca entre Estado e indivíduo: não pode haver um Estado protetor sem indivíduos detentores de direitos, nem indivíduos detentores de direitos sem um Estado protetor. Em outras palavras, o Estado só pode proteger, de fato, o individuo adjudicando-lhe direitos a serem exercidos contra outros indivíduos e contra o próprio Estado, se necessário; ao mesmo tempo, um indivíduo só detém direitos efetivos sob a proteção de um Estado que assegure o seu exercício. Estado e indivíduo definem-se um pelo outro, assim, pela mão da proteção: o indivíduo é o alvo da proteção do Estado e o Estado é o destinatário das demandas de proteção do indivíduo. $\mathrm{O}$ conteúdo da proteção oferecida ao indivíduo pelo Estado se dá pelos termos do contrato social. A primeira versão, por assim dizer, desse contrato social determinava que tal proteção deveria abranger tão somente o que hoje identificamos como a esfera da "segurança pública": a garantia de uma segurança em sentido físico, que reduzia a proteção ao direito à vida e à propriedade.

Mais tarde, acontecimentos como a expansão do movimento democrático e igualitário (que amplia o rol de suas bandeiras englobando direitos outros que não só a vida e a propriedade), o enraizamento da sociedade de mercado (através do qual a sociedade abandona uma concepção orgânica de si mesma, deixando de enxergar-se como um corpo para entender-se como um mercado), o movimento de laicização (que substitui a incerta e difusa providência religiosa pela providência estatal) e, enfim, pelo desenvolvimento da ciência atuarial e da estatística (que viabilizaram tecnicamente o exercício de determinadas funções de providência pelo Estado), levam à transição do Estado protetor clássico ao Estado providência, semeando as condições nas quais "El Estado protector (de seguridad ciudadana) podrá convertirse en el Estado providencia (de seguridad social)" (ibid., p. 42) e ampliando os termos do contrato social. Rosanvallon entende o Estado providência como uma radicalização do Estado protetor clássico. Com efeito, segundo Rosanvallon, o Estado providência não se opõe ao Estado protetor, mas, na verdade, leva a ideia de proteção, como tarefa precípua do Estado, às suas últimas consequências. O Estado providência expande e aprofunda o Estado protetor ao incorporar novas pautas de proteção. Sob o Estado providência, as redes sociais intermediárias tornam-se redundantes, já que 
prescindíveis em vista da proteção que o Estado garante ao indivíduo. Diz Rosanvallon que "El Estado providencia quiere liberar al individuo simplificando lo social” (ibid., p. 58), isto é, reduzindo a esfera do social a dois atores: Estado e indivíduo. É nesse sentido que Rosanvallon interpreta a afirmação de Le Chapelier, segundo quem "no existe más que el interés de cada individuo y el interés general" (ibid., p. 58). Ao mesmo tempo, é no momento em que o indivíduo é finalmente liberado da trama de vínculos sociais que se colocavam entre ele e o Estado, ficando sem o amparo de uma rede social intermediária, que a ampliação da pauta de proteção estatal se faz necessária. Por assim dizer, é no momento em que se afirma o indivíduo total, segundo Rosanvallon, que o Estado protetor clássico tem que se transformar no Estado providência. Assim, individualização e Estado caminham juntos: o Estado providência, ao mesmo tempo, supõe a individualização e contribui para o seu aprofundamento.

O segundo nível do processo de individualização, que decorre justamente da dissolução das redes intermediárias de vinculação social promovida pelo mercado e pelo Estado, consiste na perda de seguranças tradicionais, isto é, no esfacelamento de crenças, modos de fazer e normas que orientavam a conduta do indivíduo. Trata-se, segundo Beck, da dimensão de desencanto da individualização (BECK, 2006). O embotamento de padrões externos de conduta tem, como contrapartida, o surgimento da referencialidade interna da vida. À medida que o indivíduo se torna o eixo da vida social, ele deixa de pautar seu comportamento conforme os parâmetros que são dados externamente e passa a buscar referenciais para a ação dentro de si próprio.

A ideia de reflexividade, utilizada tanto por Giddens quanto por Beck, se relaciona com esse fenômeno. Como ressalta José Maurício Domingues, a noção de reflexividade de Giddens e de Beck é tributária da filosofia racionalista ocidental, na qual razão e reflexão são encaradas como categorias vizinhas, cujas fronteiras são bastante fluidas. A proximidade entre as noções de razão e de reflexão remonta, segundo Domingues, ao pensamento de Descartes, em que a reflexão aparece como a capacidade que tem a consciência de pensar sobre si mesma e a razão, por sua vez, é retratada como um atributo do indivíduo que opera conforme o princípio da dúvida radical (DOMINGUES, 2004). Se a razão se expressa pelo questionamento metódico de todo o conhecimento, a reflexão, como questionamento da própria atividade de conhecer, é um processo essencialmente racional. É, ademais, um processo que tem como agente o indivíduo, como portador da 
razão. Desse modo, aproximar reflexão e razão é filiar-se, de acordo com Domingues, a uma concepção essencialmente individualista da reflexividade. Segundo Domingues, outras correntes de pensamento, dentre as quais se destaca o interacionismo simbólico, dão à noção de reflexividade uma tonalidade mais coletiva, uma vez que acreditam que o movimento de retorno da consciência sobre si mesma é mediado por símbolos cujo sentido é socialmente construído, especialmente pela linguagem. Mas, conforme Domingues, a noção de reflexidade de Beck e Giddens, não obstante a crítica que fazem à onipotência atribuída à razão pelo projeto iluminista, não dá conta da dimensão social do fenômeno, permanecendo atrelada à filosofia racionalista. A filiação ao racionalismo implica também uma concepção individualista da reflexividade. Associar a reflexividade à razão significa aceitar o protagonismo do indivíduo, como agente racional, no processo de reflexão. Daí a estreita conexão existente entre reflexividade e individualização no pensamento desses autores. Para analisarmos essa conexão, é necessário antes, no entanto, compreender melhor o que Giddens e Beck entendem por reflexividade.

De acordo com Giddens, a reflexividade é uma das características mais importantes da sociedade moderna. Tanto para Giddens quanto para Beck, no entanto, a reflexividade da sociedade moderna não se esgota na reflexão, isto é, não se reduz à tematização da sociedade por ela própria. A reflexividade, no contexto da modernidade, é a reflexão somada a algo mais, que, na teoria de Giddens, é a "revisão crônica das práticas sociais à luz do conhecimento sobre estas práticas" (GIDDENS, 1991, p. 47) e, na teoria de Beck, a “autoconfrontação” da sociedade industrial consigo mesma (BECK, 1997, p. 16).

Reflexão, para Giddens, é o monitoramento que toda sociedade faz das próprias práticas sociais. Nas sociedades tradicionais, esse monitoramento se prestava tão-somente à atualização de práticas passadas em formas presentes, sem que esse processo implicasse a inovação ou a variação dessas práticas. Nas sociedades modernas, o monitoramento das práticas sociais não visa à sua continuidade no transcurso do tempo, mas, ao contrário, enseja a sua incessante revisão. A singularidade do monitoramento levado a cabo na modernidade radica em que ele engendra, justamente, uma contínua transformação das práticas sociais. Nas palavras de Giddens, "a reflexividade da vida social moderna consiste no fato de que as práticas sociais são constantemente examinadas e reformadas à luz de informação renovada sobre essas próprias práticas, alternando assim constitutivamente seu caráter" (GIDDENS, 1991, p. 45). Assim, Giddens distingue entre reflexão, como simples 
monitoramento das práticas sociais, e reflexividade, como possibilidade de revisão contínua dessas práticas. Beck também diferencia reflexão e reflexividade. De acordo com ele, reflexão consiste na capacidade que têm os sujeitos de pensar sobre as condições sociais da própria existência, ao passo que reflexividade diz respeito ao processo pelo qual a sociedade industrial está, paulatinamente, revolucionando as suas próprias bases. A reflexão implica consciência, mas a reflexividade, não necessariamente: o mecanismo pelo qual a sociedade industrial se confronta com suas próprias premissas, dissolvendo-as, pode, segundo Beck, operar "subrrepticiamente", de maneira não refletida (BECK, 1997, p. 17). Reflexão é um processo de conhecimento, enquanto reflexividade é um processo de autodissolução. A sociedade moderna, segundo Beck, é, sem dúvida, uma sociedade propensa à reflexão, à medida que aspira, mais que as sociedades tradicionais, a conhecer a si mesma; mas, independentemente disso, é também uma sociedade reflexiva, já que caminha, de modo consciente ou não, para a dissolução das estruturas em que está ancorada ou, em outras palavras, para a abolição dos seus próprios fundamentos.

É com base na noção de reflexividade que Giddens e Beck distinguem entre a modernidade simples e a modernidade reflexiva. A modernidade reflexiva diz respeito a um período histórico, identificado com as últimas décadas do século XX, que testemunhou a radicalização da modernidade (GIDDENS, 1991, p. 13). Trata-se de um período, por assim dizer, de incremento da reflexividade. Para Giddens, isso significa que a revisão crônica das práticas sociais adquiriu um ritmo ainda mais intenso e um alcance universal o que ele atribui, sobretudo, ao fenômeno da globalização - e, para Beck, quer dizer que a sociedade industrial se encontra em um momento decisivo de confrontação com suas próprias bases, no qual avança o processo de autodissolução.

A conexão entre reflexividade e indivíduo que subjaz ao pensamento de Giddens e Beck, revelada por Domingues, fica mais clara quando se examinam as consequências do advento da chamada modernidade reflexiva sobre o indivíduo. Para Giddens, a modernidade reflexiva é responsável por um fenômeno que ele chama de "transformação da intimidade", trazendo repercussões sobre a forma como o indivíduo organiza a própria identidade e encara as suas relações pessoais. Para Beck, a dissolução das premissas da sociedade industrial significa um aprofundamento do processo de individualização, que também afeta o modo como o indivíduo percebe a própria biografia. 
Em condições de modernidade reflexiva, para Giddens, o próprio "eu” torna-se um projeto reflexivo. A identidade não é mais algo que é atribuído, desde fora, ao indivíduo, conforme a posição relativa que ocupa em um dado arranjo social. Na modernidade reflexiva, ela se transforma em uma "autoidentidade", à medida que é construída pelo próprio indivíduo. De acordo com Giddens, "autoidentidade é "o eu compreendido reflexivamente pela pessoa em termos de sua biografia" (GIDDENS, 2002, p. 54). Em outras palavras, consiste na reinterpretação constante que o indivíduo faz da sua própria trajetória de vida. Em sociedades tradicionais, o conteúdo da identidade já estava dado pelo status do indivíduo; nas sociedades modernas, a matéria-prima que constitui a identidade são as decisões tomadas pelo indivíduo ao longo de sua vida, à luz das quais ele pratica a "revisão crônica"de sua biografia. A construção da autoidentidade está relacionada, de um lado, à adoção de estilos de vida e, de outro, ao planejamento da vida. Giddens define estilo de vida como o "conjunto mais ou menos integrado de práticas que um indivíduo abraça, não só porque essas práticas preenchem necessidades utilitárias, mas porque dão forma material a uma narrativa particular da autoidentidade" (ibid., p. 79) e planejamento da vida como "um meio de preparar um curso de ações futuras mobilizadas em termos de biografia do eu" (ibid., p. 83). Assim, através das escolhas e dos planos que o indivíduo faz tendo em conta seu próprio percurso biográfico, ele organiza sua autoidentidade.

A construção reflexiva do "eu" induz o indivíduo a buscar, como norte de sua conduta, referências que extrai de sua autoidentidade, isto é, de suas escolhas e seus planos, e não de padrões externos de comportamento. É isso que Giddens chama de referencialidade interna da vida (ibid., p. 136). Com o fenômeno do distanciamento do tempo e do espaço, que discutiremos mais detidamente adiante, as relações são retiradas de seus contextos locais e os referenciais externos ligados à localidade deixam de desempenhar um papel influente na determinação da conduta individual. Diz Giddens que "Sem as referências externas fornecidas pelos outros, a vida mais uma vez surge como uma trajetória relacionada acima de tudo aos projetos e planos do indivíduo" (ibid., p. 138).

Com a internalização dos referenciais da vida, a sensação de inconsistência da própria autoidentidade passa a gerar maior ansiedade, para o indivíduo, do que a transgressão de padrões externos de comportamento. Por isso, de acordo com Giddens, a culpa dá lugar à vergonha como fonte preponderante de ansiedade do "eu reflexivo". Segundo Giddens, a culpa é uma forma de ansiedade que deriva da consciência de que os 
pensamentos ou as ações do indivíduo não correspondem a determinadas expectativas sociais. A vergonha, por sua vez, é um tipo de ansiedade que decorre da percepção de que o "eu" não corresponde às expectativas que o próprio indivíduo tem de si mesmo (ibid., p. 65). A culpa é a expressão de um erro - de uma conduta incorreta -, ao passo que a vergonha é a expressão de uma incoerência pessoal - da incapacidade do indivíduo de sustentar uma biografia adequada à sua própria autoidentidade. A vergonha evidencia uma fissura na própria integridade do "eu" e, por isso, segundo Giddens, seus efeitos são muito mais desestabilizadores para a autoidentidade do que aqueles relacionados à culpa.

A referencialidade interna da vida também está ligada ao aparecimento de um tipo peculiar de relacionamento pessoal que Giddens chama de "relação pura". Em sociedades tradicionais, os relacionamentos pessoais estavam ancorados em condições externas à própria relação, tais como vínculos de sangue, dependência econômica, obrigações de lealdade, etc. Tais condições exerciam uma espécie de efeito inercial sobre o relacionamento, à medida que promoviam a sua continuidade independentemente da satisfação pessoal que a relação em si mesma proporcionasse às partes. Uma relação pura, de acordo com Giddens, é um relacionamento que não se apoia em nenhuma âncora externa, dependendo apenas das recompensas que a própria relação oferece às partes em termos afetivos ou de realização pessoal. A relação dura, assim, enquanto durarem as recompensas inerentes à relação, o que significa que também as relações pessoais passam a estar sujeitas à "revisão crônica". Bauman critica a noção de "relação pura" afirmando que "os relacionamentos humanos tendem a preencher, infestar e modificar todos os recessos e frestas, por mais remotos, do Lebenswelt, de modo que podem ser tudo menos "puros"” (BAUMAN, 2004, p. 63). De fato, os relacionamentos humanos, em geral, se imiscuem em diversas esferas da vida, mas isso não põe em xeque o fato de que o estabelecimento e a continuidade desses relacionamentos tendem, realmente, a depender cada vez menos de condições externas. O que sustenta a relação pura, substituindo essas condições externas, conforme Giddens, é o compromisso das partes, que é construído à medida que elas se abrem uma à outra e se revelam reciprocamente, de modo íntimo e autêntico. Com efeito, considerando que o contato que se estabelece em relacionamentos tradicionais é muitas vezes vazado em fórmulas ritualizadas que exigem pouco engajamento pessoal entre as partes, as relações puras promovem, segundo Giddens, um grau inédito de intimidade e de autenticidade nos relacionamentos pessoais. Mesmo as relações familiares, diz Giddens, 
estão paulatinamente se ajustando à dinâmica das relações puras. De acordo com ele, embora ainda minimamente respaldadas em critérios externos, como os vínculos biológicos e de subsistência, elas tendem, à medida que se seus protagonistas são liberados dos deveres tradicionalmente atribuídos aos papéis familiares, a tornarem-se relações meramente nominais, caso não representem algo em termos de satisfação pessoal para as partes (GIDDENS, 2004, p. 94). De qualquer forma, as relações puras contêm em si, segundo Giddens, uma ambiguidade importante: se, por um lado, o engajamento construído sobre a intimidade proporciona às partes certo conforto emocional, por outro lado, a possibilidade latente de rompimento é um fator de vulnerabilidade (ibid., p. 172). Trata-se, portanto, de uma relação que evoca, ao mesmo tempo, sensações de estabilidade e instabilidade.

A ênfase na intimidade que caracteriza as relações puras tem, segundo Richard Sennett, inundado todas as esferas da vida social. De acordo com ele, vivenciamos hoje uma confusão entre vida pública e vida íntima: "as pessoas tratam em termos de sentimentos pessoais os assuntos públicos, que somente poderiam ser adequadamente tratados por meio de códigos de significação impessoal” (SENNETT, 1988, p. 18). Sennett atribui esse fenômeno de colonização do domínio público pela intimidade a, pelo menos, três fatores: ao desenvolvimento do capitalismo, que levou as pessoas a buscarem refúgio contra a instabilidade da vida econômica na intimidade do lar, com o que se desenhou uma imagem idealizada da família como porto seguro do indivíduo; à emergência, no campo epistemológico, de um tipo de secularismo que pontificava que as manifestações tangíveis de um dado objeto eram a expressão visível de sua essência invisível, fazendo ruir, assim, a separação entre as dimensões externa e interna do objeto de conhecimento; e, enfim, à individualização da experiência do público, já que, embora o domínio público sempre houvesse sido considerado como um cenário privilegiado em que as pessoas poderiam experimentar sensações ou formas de relacionamento humano que não poderiam experimentar em nenhum outro contexto social, ele deixou de ser concebido como o espaço de tolerância em que os encontros sociais podiam escapar aos padrões rígidos de moralidade que os regiam na vida privada, como sucedia no ambiente da corte do Antigo Regime, para ser interpretado como um espaço no qual o indivíduo tem de aprender a circular como condição necessária a seu próprio desenvolvimento pessoal, com o que a sua 
importância deixou de ser relacionada à formação de esquemas diferentes de sociabilidade para estar ligada, sobretudo, à formação da personalidade do indivíduo (ibid., p. 34).

A consequência dessa mudança na percepção a respeito do domínio público, de acordo com Sennett, é uma perda de civilidade. Civilidade, para Sennett, é a máscara de impessoalidade, usada no cotidiano dos contatos sociais, que impede que uma pessoa sobrecarregue a outra com o seu próprio “eu” (ibid., p. 323). A impessoalidade, no entanto, é considerada um mal, à medida que, hoje, tratar alguém "como uma pessoa" significa, justamente, expor a sua própria intimidade e incentivar o outro a expor a sua. Com efeito, conforme Sennett, todos os encontros sociais tendem atualmente a assumirem a forma de uma "troca mercantil de intimidades" ou de uma "permuta de autorrevelações": "eles lhes mostram uma carta, vocês lhes mostram outra" (ibid., p. 23). Quando as pessoas já não tem mais revelações recíprocas a fazer, a transação comercial chega ao fim e o relacionamento acaba.

Do ponto de vista de Beck, os efeitos da modernidade reflexiva sobre o indivíduo tem a ver com o terceiro nível do processo de individualização, ao qual não havíamos chegado até agora. Depois que o indivíduo é liberado dos vínculos sociais tradicionais e são dissolvidos os referenciais externos conforme os quais ele pautava sua conduta, ele tem de ser reacomodado em um novo arranjo social. Esse terceiro nível, portanto, se refere à formação de um novo tipo de coesão social e é denominado, por Beck, de dimensão de integração (BECK, 2006). Conforme Beck, a individualização é também um processo de institucionalização, uma vez que é acompanhada do desenho de novas instituições adequadas a respaldar a nova situação social do indivíduo. A matéria-prima utilizada para a construção institucional da modernidade simples foram os despojos da própria sociedade tradicional. É como se, nessa primeira etapa da modernidade, alguns elementos típicos da sociedade tradicional tenham sido reformados e rearranjados em uma nova disposição. Nesse sentido, conforme Beck, a sociedade industrial, que emerge como produto desse rearranjo, é uma sociedade semimoderna, cujos componentes tradicionais não são uma mera relíquia do passado, mas, uma vez que são realocados sob uma nova roupagem, tornam-se construções da própria sociedade industrial, sobre os quais ela assenta suas bases. As antigas corporações, por exemplo, são atualizadas sob a forma de sindicatos e o indivíduo recém-liberado é acomodado em clivagens de classes sociais. No mesmo sentido, o indivíduo é retirado da oficina e reacomodado na fábrica e as antigas regras de 
distribuição do trabalho conforme o status de aprendiz, artesão ou mestre são substituídas pelas rígidas regras tayloristas de divisão de trabalho que, com pretensão científica, buscam aumentar a produtividade por meio da maximização da eficiência do uso do tempo, promovendo uma especialização de tarefas de acordo com cada etapa da produção.

Um outro importante componente das sociedades tradicionais que é reaproveitado pela sociedade industrial, sob uma nova forma, é a família. Uma das grandes mudanças trazidas pela emergência da sociedade industrial foi a cisão entre as esferas de produção e de reprodução da vida social. A família foi despojada de suas funções propriamente econômicas pelo mercado, à medida que, com emergência do mercado, o indivíduo foi forçado a vender a sua própria força de trabalho em vez de aplicá-la em atividades produtivas desenvolvidas, de modo autônomo, no seio da unidade familiar. Richard Sennett comenta que a fábrica de papel que Diderot descreve como modelo na sua Encyclopédie foi uma das primeiras da França a recrutar seus trabalhadores de lugares tão distantes que eles tinham que se deslocar até o local de trabalho a cavalo, uma vez que a fábrica não lhes provia habitação, além de ser também uma das primeiras a pagar os salários de trabalhadores adolescentes diretamente a eles próprios e não a seus pais. Para Sennett, a fábrica de Diderot representa uma nova ordem do trabalho, liberada do domus, que torna anacrônico o cenário, predominante até então, em que oficina e casa ocupavam o mesmo espaço físico (SENNETT, 2005). A fábrica de alfinetes de Adam Smith, descrita na sua obra $A$ riqueza das nações, é também um lugar para trabalhar e não para viver e, de acordo com Sennett, a separação entre casa e trabalho era para Smith a mais importante de todas as formas modernas de divisão do trabalho. Se, no entanto, a família perde o seu protagonismo na esfera das relações de produção, recaem sobre ela, no contexto da sociedade industrial, importantes responsabilidades relativas à reprodução da vida social, especialmente as tarefas de cuidado relacionadas à manutenção da casa, à criação dos filhos e à assistência aos idosos, atribuídas à mulher.

Nas últimas décadas, entretanto, com a entrada da mulher no mercado de trabalho, tornou-se impossível que as demandas de reprodução social de que ela se encarregava fossem equacionadas todas no âmbito familiar, alheias à mediação do mercado. A modernidade reflexiva é um período de aprofundamento do processo de individualização no qual a espiral da individualização penetra também na família: 
la espiral de individualización entra también dentro de la familia (...). La familia se convierte en un malabarismo continuo con las ambiciones contradictorias entre las exigencias del trabajo, los imperativos de la educación, las obligaciones de los niños y la monotonía del trabajo doméstico. Surge el tipo de la 'familia negociada a plazo', en la que las situaciones individuales independizadas entran en una alianza contradictoria con el fin de intercambiar las emociones de una manera reglada y hasta nuevo aviso (BECK, 2006, p. 124).

Na perspectiva de Bauman, a abertura da família ao processo de individualização integra um contexto maior de expansão vertical da economia de mercado sobre o que ele chama de "economia moral". A economia moral, conforme Bauman, é:

Um mundo em que a solidariedade, a compaixão, a troca, a ajuda e a simpatia mútuas (noções estranhas ao pensamento econômico e abominadas pela prática econômica) suspendem ou afastam a escolha racional e a busca do autointeresse. Um mundo cujos habitantes não são nem concorrentes nem objetos de uso e de consumo, mas colegas (ajudantes e ajudados) no esforço contínuo e interminável de construir vidas compartilhadas e torná-las possíveis (BAUMAN, 2004, p. 91).

Segundo Bauman, então, aprofundar o processo de individualização no âmbito familiar significa submeter a família ao jugo do mercado. A modernidade simples, ao subtrair da família suas funções produtivas, acabou, de uma certa maneira, blindando-a contra o tipo de racionalidade que rege as relações econômicas. A família, por assim dizer, permaneceu como um oásis governado por uma lógica diversa daquela reinante no deserto do mercado. De acordo com Beck:

bajo la forma de la reproducción familiar y de la producción en el mercado están reunidas en el proyecto de la sociedad industrial dos épocas con principios organizativos y sistemas axiológicos contrapuestos (modernidad y antimodernidad), las cuales se complementan, se condicionan y se contradicen" (BECK, 2006, p. 182).

A modernidade reflexiva, portanto, trata de resolver essa contradição, rompendo a armadura da família e deixando que as forças de mercado tomem conta dela. Para Beck, ela consiste na modernização das bases tradicionais, incluída a família, da sociedade industrial. É a isso que Beck se refere quando fala em autoconfrontação ou em autodissolução da sociedade industrial. Ao introduzirem no debate sociológico a noção de modernidade reflexiva, Beck e Giddens tentam dar conta de desdobramentos da 
modernidade que não se colocavam no horizonte de Tönnies e Durkheim. Como bem explica Lash:

\begin{abstract}
Não está mais em questão aqui a justaposição direta e dicotômica da tradição e da modernidade, cara aos papas da teoria sociológica clássica Weber, Durkheim, Simmel e Tönnies. Em vez disso, está em questão uma concepção de três estágios da mudança social - da tradição para a (simples) modernidade à modernidade reflexiva. Nesta visão, as sociedades simplesmente modernas não são plenamente modernas. Neste contexto, a modernidade reflexiva vem depois da modernidade simples. Colocado de outra maneira, a sociedade tradicional corresponde aqui à Gemeinschaft; a modernidade simples à Gesellschaft; e sua sucessora a uma Gesellschaft que se tornou inteiramente reflexiva. Neste processo, o motor da mudança social é a individualização. Neste contexto, a Gesellschaft ou modernidade simples é moderna no sentido de que a individualização quebrou as antigas estruturas tradicionais - grupo familiar amplo, Igreja, comunidade da aldeia - da Gemeinschaft. Mas não é inteiramente moderna porque o processo de individualização foi parcial e um novo conjunto de estruturas gesellschaftich - sindicatos, welfare state, burocracia de governo, regras básicas tayloristas formalizadas, a classe em si como uma estrutura - assumiu o lugar de estruturas tradicionais. A modernização plena só acontece quando uma maior individualização também liberta a ação até dessas estruturas sociais (simplesmente) modernas (LASH, 1997, p. 139).
\end{abstract}

Do ponto de vista do indivíduo que é "liberado" das estruturas da modernidade simples, o grande problema, de acordo com Bauman, é que, se a modernidade simples desacomodava o indivíduo para reacomodá-lo sob um esquema diverso, no contexto da modernidade reflexiva, "não são fornecidos 'lugares' para a 'reacomodação' e os lugares que podem ser postulados e perseguidos mostram-se frágeis e frequentemente desaparecem antes que o trabalho de 'reacomodação' seja completado" (BAUMAN, 2001, p. 42). Bauman também faz um diagnóstico dúplice da modernidade, dividindo-a em modernidade sólida e modernidade líquida. De acordo com ele, a modernidade sólida consistiu na substituição da moldura da tradição por uma outra moldura, tão rígida quanto a da sociedade tradicional. A modernidade líquida, por sua vez, corresponde a um período em que essa moldura da modernidade sólida é liquefeita e o indivíduo se vê, de fato - e com o perdão da tautologia -, completamente individualizado.

Em um contexto de extrema individualização, a referencialidade interna a que o indivíduo está condenado faz com que toda a sua leitura da realidade social redunde nele próprio. Por assim dizer, o indivíduo, incapaz de enxergar além de si mesmo, torna-se a 
própria lente através da qual interpreta a realidade e constrói, assim, uma "imagen del mundo centrada en el yo" (BECK, 2006, p. 221). Dessa forma, "las crisis sociales aparecen como crisis individuales y ya no son percibidas (o sólo de una manera muy mediada) en su socialidad" (ibid., p. 163). Problemas sociais são computados como fracassos pessoais e o indivíduo é levado a buscar soluções biográficas para contradições que, a bem da verdade, são sistêmicas. Como nota Bauman, o indivíduo passa a ser eixo de variadas pautas de responsabilização:

se ficam doentes, supõe-se que foi porque não foram suficientemente decididos e industriosos para seguir seus tratamentos; se ficam desempregados, foi porque não aprenderam a passar por uma entrevista, ou porque não se esforçaram o suficiente para encontrar trabalho ou porque são, pura e simplesmente, avessos ao trabalho; se não estão seguros sobre as perspectivas de carreira e se agoniam sobre o futuro, é porque não são suficientemente bons em fazer amigos e influenciar pessoas e deixaram de aprender e dominar, como deveriam, as artes da autoexpressão e da impressão que causam. (...) Riscos e contradições continuam a ser socialmente produzidos; são apenas o dever e a necessidade de enfrentá-los que estão sendo individualizados (BAUMAN, 2001, p. 43).

Uma das faces perversas da individualização radica no fato de que ela não distingue entre o indivíduo de facto, isto é, aquele que tem controle efetivo sobre as próprias escolhas e, portanto, para quem a individualização representou realmente a abertura de um leque maior de possibilidades de autoafirmação, o indivíduo de jure, aquele para quem a autoafirmação é um projeto virtualmente infactível e a individualização é, assim, uma fatalidade e não uma escolha. A noção de "indivíduo de jure" demonstra que o indivíduo, mesmo que trate de pautar sua vida por referenciais internos a ele próprio, não está a salvo de constrangimentos externos, que circunscrevem o seu espectro de escolhas. De acordo com Bauman, a modernidade líquida está aumentando o abismo entre os indivíduos de facto e os indivíduos de jure (ibid., p. 43). A transposição desse abismo, segundo ele, não é uma tarefa que possa ser levada a cabo individualmente, mas que exige uma iniciativa de caráter coletivo.

Nesse sentido, uma das características mais marcantes da modernidade líquida, segundo Bauman, é o que ele chama de "privatização das tarefas modernizantes" (ibid., p. 38). Com isso, Bauman quer dizer que o projeto coletivo de emancipação que estava embutido na modernidade se transformou em um projeto individual de autorrealização. 
Noções como as de "autoidentidade" e de "relação pura", ao evocarem essa preocupação com a autorrealização, demonstram essa transformação. Ela é ainda mais evidente, todavia, nos conceitos de "política-vida", de Giddens, e "subpolítica", de Beck.

De acordo com Giddens, as transformações que implicaram a transição da modernidade simples à modernidade reflexiva trouxeram mudanças também em termos de agenda política. Uma forma determinada de fazer política que Giddens chama de "política emancipatória" tende a perder lugar para outra forma de prática que ele denomina de "política-vida". Segundo Giddens, a política emancipatória remete a visões de mundo interessadas em libertar indivíduos e coletividades das "limitações que afetam negativamente suas oportunidades de vida" e em superar a "dominação ilegítima de alguns indivíduos e grupos sobre outros" (GIDDENS, 2002, p. 194). A política-vida, por sua vez, é uma política praticada por meio de decisões pessoais, especialmente da adoção de estilos de vida. Ela supõe que iniciativas individuais inscritas em projetos pessoais de construção da autoidentidade podem ter repercussões mais amplas, influenciando estratégias políticas de caráter geral. Uma ideia semelhante pode ser encontrada na noção de "subpolítica" de Beck. Trata-se de uma forma de política praticada em arenas alternativas, como o campo do direito e o dos meios de comunicação, por exemplo. O campo, no entanto, que aproxima a subpolítica da política-vida é o da privacidade. Beck também admite que determinadas questões em torno das quais homens e mulheres estruturam suas condições de vida têm uma dimensão política mais transcendente. Beck cita a questão da natalidade, ressaltando que a decisão a respeito da quantidade de filhos a se ter, que compete exclusivamente ao casal, tem impactos sobre a política social, a política tributária e a política laboral, por exemplo (BECK, 2006). Bauman, por sua vez, é critico dessas noções, afirmando que, quando a política-vida assume, os esforços dos indivíduos de jure para se tornarem indivíduos de facto "passam a ser não aditivos e não-cumulativos, destituindo assim a esfera pública de toda substância que não seja a do lugar em que aflições individuais são confessadas e expostas publicamente" (BAUMAN, 2001, p. 63). Para evitar que o domínio público se reduza a um espaço de exposição da intimidade, como alertou Sennett, Bauman propõe o resgate de um projeto político coletivo, com a retomada do que ele chama de "Política com P maiúsculo" (ibid., p. 49). 


\subsubsection{Distanciamento do tempo e do espaço}

O embotamento de referenciais externos da conduta individual está ligado, em grande medida, ao fenômeno do distanciamento do tempo e do espaço, o qual, segundo Giddens, é uma das características mais importantes da modernidade. Como vimos, por meio da repetição, a tradição gerenciava tempo e espaço, vinculando o passado, o presente e o futuro entre si e a um território determinado. Na modernidade, tempo e espaço são distendidos e transcendem as fronteiras da localidade, com o que se desenraizam as relações sociais de seus contextos tradicionais. Ocorre, então, um fenômeno que Giddens chama de "desencaixe", isto é, o "deslocamento das relações sociais de seus contextos locais de interação e sua reestruturação através de extensões indefinidas de tempo-espaço" (GIDDENS, 1991, p. 29).

Giddens identifica dois mecanismos por meio dos quais opera esse desencaixe: as fichas simbólicas e os sistemas especializados. As fichas simbólicas são, de acordo com ele, meios de intercâmbio para cuja circulação são irrelevantes tanto as características particulares dos indivíduos ou grupos que os manuseiam como o contexto específico em que se dá essa circulação (ibid., p. 30). O melhor exemplo de ficha simbólica é o dinheiro. Ao discorrer sobre o dinheiro, Karl Marx atenta para o fato de que o dinheiro fraciona a relação de troca em duas etapas. A relação de troca consiste, essencialmente, no oferecimento, por uma pessoa, de uma mercadoria sua a uma outra pessoa que disponha de uma mercadoria qualquer que ela deseje. Ela pressupõe, no entanto, que o valor das mercadorias que se pretende trocar seja equivalente. $O$ dinheiro nada mais é que uma mercadoria que, com o tempo, torna-se, nos termos de Marx, o "equivalente geral”, isto é, o padrão a partir do qual o valor de todas as outras mercadorias é medido. Ao desempenhar essa função, o dinheiro passa a intermediar todas as relações de troca. O indivíduo primeiro troca sua mercadoria por dinheiro para, depois, trocar esse dinheiro pela mercadoria que efetivamente deseja. Trata-se do processo que Marx chama de "metamorfose da mercadoria": uma mercadoria se metamorfoseia em dinheiro para, posteriormente, se transformar em mercadoria novamente. $O$ fracionamento da relação de troca pela "metamorfose da mercadoria" em dinheiro introduz uma espécie de "intervalo" nesse relação, "uma vez que ninguém é obrigado a comprar, apenas por ter vendido" (MARX, 1975 [1867], $1^{\text {o }}, \mathrm{I}$, p. 126). Isso quer dizer que a segunda etapa da relação de troca não precisa se seguir imediatamente à primeira: ela pode ser adiada e, assim, se realizar em 
circunstâncias de tempo e de espaço totalmente distintas daquelas em que se deu a primeira etapa, além de envolver um terceiro indivíduo diferente daquele que figurou na primeira fase da troca. Desse modo, "a circulação [do dinheiro] rompe com as limitações de tempo, de espaço e individuais, impostas pela troca de produtos, ao dissociar a identidade imediata que, nesta última, une a alienação do produto próprio e a aquisição do alheio" (ibid., p. 126).

Os sistemas especializados, por sua vez, são "sistemas de excelência técnica ou competência profissional que organizam grandes áreas dos ambientes material e social em que vivemos hoje" (GIDDENS, 1991, p. 35). A vida moderna está povoada de aplicações do conhecimento técnico produzido por campos de saber especializados. Estamos continuamente envolvidos com sistemas especializados no nosso cotidiano, à medida que os objetos que manuseamos, os ambientes em que circulamos e os contatos que travamos remetem todos a alguma área de conhecimento perito. Por exemplo, se entramos em um carro, transitamos pelas vias públicas e nos encaminhamos a uma consulta em um hospital, estamos manuseando um objeto que remete ao sistema da engenharia, circulando por um ambiente que remete ao sistema do urbanismo e travando contatos que remetem ao sistema da medicina. Esse envolvimento contínuo, no entanto, não supõe sempre um contato direto com os profissionais que integram os sistemas especializados - de acordo com Giddens, o encontro com os representantes desses sistemas se dá apenas em "pontos de acesso" (ibid., p. 91), isto é, situações em que os compromissos tipicamente "sem rosto" que caracterizam os sistemas especializados se transformam em compromissos "com rosto", estabelecidos em condições de co-presença. Tampouco supõe que o indivíduo que se socorre de objetos, transita por ambientes ou se relaciona com peritos vinculados a sistemas especializados tenha familiaridade com o tipo de conhecimento técnico produzido por eles - pelo contrário, a maior parte das pessoas é leiga no que se refere ao funcionamento da maior parte dos sistemas especializados e, de acordo com Giddens, os sistemas especializados promovem uma "desqualificação" dos indivíduos, ao se apropriarem do conhecimento. É por esses motivos que os sistemas especializados são mecanismos de desencaixe: trata-se de relações sociais que se estabelecem, por meio das aplicações práticas de conhecimento técnico com as quais se tem contato diuturno, sem qualquer referência às características pessoais dos indivíduos envolvidos em contextos variados de espaço e tempo. 
Em termos de relacionamentos pessoais, o distanciamento do tempo e do espaço faz que as relações entre presentes passem a rivalizar, na vida social, com relações entre ausentes, mediadas, justamente, por fichas simbólicas e construções de sistemas especializados (ibid., p. 27). Como afirma Bauman, hoje "a proximidade não exige mais a contiguidade física; e a contiguidade física não determina mais a proximidade" (BAUMAN, 2004, p. 81). Essa frase resume duas grandes mudanças trazidas pela modernidade: em primeiro lugar, em razão do avanço dos meios de comunicação, o estabelecimento e conservação de relações de proximidade já não dependem da convivência das partes em um mesmo local; em segundo lugar, nem todas as relações estabelecidas dentro de um mesmo marco de localidade consistem mais em relações de proximidade, como tendia a acontecer em sociedades tradicionais. Comumente, aliás, não obstante a contiguidade física, elas costumam ser relações entre estranhos. De acordo com Georg Simmel, o "estranho" é o indivíduo que nos é ao mesmo tempo próximo e distante: ele "nos es próximo en cuanto sentimos que entre él y nosotros se dan igualdades sociales, profesionales o simplesmente humanas; en cambio nos es lejano en cuanto que esas igualdades están por encima de ambos, y sólo nos ligan porque ligan asimismo a otros muchos" (SIMMEL, 1939 [1908], II, p. 277). Assim, nos aproximamos de estranhos à medida que com eles compartilhamos alguma situação de caráter genérico, mas a generalidade da situação não é suficiente para engendrar uma relação de efetiva proximidade. Daí que o contato com estranhos tenha quase sempre um caráter episódico, que não pressupõe sua continuidade. De fato, como diz Bauman, "O encontro com estranhos é um evento sem passado. Frequentemente é também um evento sem futuro (o esperado é que não tenha futuro), uma história para 'não ser continuada', uma oportunidade única a ser consumada enquanto dure e no ato, sem adiamento e sem deixar questões inacabadas para outra ocasião" (BAUMAN, 2001, p. 111). A instantaneidade dos encontros com estranhos, nas sociedades modernas, é um sintoma da fragmentação das relações multiplexas típicas das sociedades tradicionais: os contatos se firmam com um propósito único, em que cada parte desempenha um só papel social, e se desfazem assim que esse propósito é alcançado.

A alusão ao dinheiro e a campos de saber técnico-profissionais como mecanismos de desencaixe evidencia que o fenômeno do distanciamento do tempo e do espaço está também intimamente relacionado a dinâmicas ocorridas no seio da vida econômica. $\mathrm{O}$ 
capitalismo é um sistema econômico que, em termos schumpeterianos, vigora sob uma incessante "destruição criativa". A tendência ilimitada de expansão do capital, que é inerente à sua própria lógica de reprodução, leva, conforme procurou demonstrar Marx, às chamadas "crises de superacumulação". O equacionamento dessas crises obrigam a um contínuo rearranjo das forças produtivas. De acordo com David Harvey, há três formas de responder as essas crises. A primeira consiste na desvalorização do capital excedente, que pode ser levada a cabo, por exemplo, pela erosão inflacionária da moeda, pela eliminação dos estoques de produtos (como a famosa queima de café acontecida nos anos 30 no Brasil) ou pela perda de valor de instalações e equipamentos. A segunda consiste no controle macroeconômico, que implica a regulação estatal da economia por meio do estabelecimento de marcos institucionais que circunscrevam a atividade econômica, de modo a manter sob controle, através de decisões políticas, o ritmo da acumulação (HARVEY, 2005, p. 170). A terceira, enfim, corresponde justamente à absorção do capital excedente pelo seu deslocamento espacial ou temporal. O deslocamento espacial consiste na expansão geográfica do capital excedente para outras áreas do globo, ao passo que o deslocamento temporal consiste tanto no desvio de capital excedente presente para aproveitamento futuro (como em investimentos de longo prazo em infra-estrutura, por exemplo) quanto na aceleração do tempo de giro do capital (com o incremento da velocidade em que o capital excedente é reinvestido) (ibid., pp. 171).

O processo de acumulação de capital pode assumir várias formas, conforme a maneira em que os componentes da produção se ajustam entre si e em relação à demanda, e cada forma particular recebe o nome de regime de acumulação (ibid., p. 117). Cada regime de acumulação se vale de combinações diferentes dessas três estratégias de contenção de crises de superacumulação. De acordo com Harvey, uma transformação no uso dessas estratégicas tem implicado, nos últimos anos, uma transição do regime de acumulação fordista ao que ele chama de "regime de acumulação flexível". Embora o regime fordista também se valesse de estratégias de deslocamento temporal e espacial, esse uso tinha seu alcance limitado tanto pelo recurso concomitante à estratégia de controle macroeconômico quanto pelo próprio arranjo em que estavam dispostas as forças produtivas e pela sua relação com a demanda. De um lado, o marco institucional existente fixava parâmetros para a atividade econômica, que podiam incluir também restrições à livre distribuição temporal e espacial dos investimentos. De outro lado, o regime fordista 
se fundava em uma produção de escala, com grandes estoques e instalações fixas em plantas de amplas dimensões, e em uma organização hierarquizada dos postos de trabalho, com um elevado grau de especialização de tarefas e de regulamentação das relações trabalhistas, sendo que tudo isso também imobilizava o capital e comprometia a agilidade de seu deslocamento temporal e espacial. O regime de acumulação flexível vem, nesse sentido, para resolver o problema de rigidez do regime fordista (ibid., p. 135), aumentando o alcance das estratégias de deslocamento temporal e espacial do capital. Esse aumento é tão radical que Harvey vislumbra como uma das suas consequências culturais um fenômeno que chama de "compressão do tempo-espaço", querendo dizer que, em nossa percepção da realidade, o tempo foi drasticamente "acelerado"e o espaço foi drasticamente "encolhido" (ibid., p. 219).

O cerne do regime de acumulação flexível é sua elevada capacidade de adequação da produção à demanda. A produção de escala é substituída pela produção de escopo, também apelidada de produção just-in-time: os grandes estoques de produtos altamente padronizados dão lugar a pequenos lotes de produtos customizados. $\mathrm{O}$ ajuste da produção à demanda supõe, no entanto, uma contínua reorganização dos componentes de produção, com máquinas que possam ser facilmente reprogramadas, instalações que possam ser facilmente redesenhadas, organizações que possam ser facilmente reestruturadas (por meio de estratégias gerenciais de reengineering ou delayering, por exemplo) e trabalhadores que possam ser facilmente realocados em tarefas ou unidades distintas e, se necessário, dispensados (daí a ênfase nos contratos temporários e de meio período, no trabalho terceirizado e em jornadas de trabalho fundadas em bancos de horas e no trabalho em casa, por exemplo). Em suma, todos os componentes da produção têm de estar de prontidão para responder à variabilidade da demanda, porque uma resposta célere permite, especialmente, a aceleração do tempo de giro do capital.

A volatilidade da demanda, assim, impregna a produção e dificulta o planejamento a longo prazo, mesmo em termos de vida pessoal. Richard Sennett analisou justamente as consequências do regime de acumulação flexível no que diz respeito à forma como os indivíduos organizam sua próprias vidas e concebem seus relacionamentos pessoais. $\mathrm{O}$ salto de emprego em emprego esvazia a noção de carreira como uma trajetória percorrida em uma direção única e impede que o indivíduo estruture sua narrativa de vida em torno de uma identidade profissional. Se utilizarmos a terminologia de Giddens, podemos dizer que 
a profissão é mais um dos referenciais externos da vida que se desbota, à medida que, por conta das mudanças constantes de emprego, deixa de ser um elemento preponderante para o indivíduo na construção da sua autoidentidade. Sennett visita novamente uma padaria que havia visitado, enquanto realizava uma outra pesquisa, vinte anos antes e nota que, se antes os trabalhadores possuíam uma forte identidade profissional e se definiam claramente como "padeiros", os trabalhadores atuais encaram sua situação de emprego como um estado provisório em suas vidas e, assim, não associam sua identidade à profissão de "padeiro". Um dos fatores que contribui para essa mudança de percepção, de acordo com Sennett, é o que ele chama e ilegibilidade do trabalho (SENNETT, 2005, p. 80). Os novos trabalhadores dispõem de fornos industriais altamente informatizados, cujo funcionamento, ativado por um simples apertar de botões, escapa à sua compreensão. Esses trabalhadores, desse modo, não estão familiarizados com o processo tradicional, baseado no trabalho manual, de feitura do pão, mas, em razão da complexidade da tecnologia utilizada, tampouco são capazes de entender completamente o novo procedimento - enfim, são padeiros que não sabem fazer pão.

Uma outra consequência da flexibilidade, em termos individuais, é a desorientação causada pela destruição da rotina. Sennett apresenta, em as obra, duas visões contrapostas acerca da rotina: a de Adam Smith, para quem a rotina embrutecia o homem, transformando-o em um autômato, e a de Diderot, para quem a rotina propiciava ao homem a obtenção de um maior domínio sobre sua atividade, possibilitando-lhe aprimorála (ibid., p. 36). Sennett sugere que, de uma forma ou de outra, a previsibilidade inerente à rotina permite que as pessoas detenham um certo controle sobre suas vidas. De acordo com Sennett, por assim dizer, a rotina pode ter um papel estruturador na vida de um indivíduo. Nesse sentido, a destruição da rotina pelo regime de acumulação flexível e seus constantes remanejamentos de tarefas e de horários de trabalho, transmite às pessoas uma sensação de deriva, de perda do controle sobre as próprias vidas.

No que se refere aos relacionamentos pessoais, a falta de perspectivas de longo prazo "corrói a confiança, a lealdade e o compromisso mútuo" (ibid., p. 24). Os atributos que se exigem do trabalhador flexível são incompatíveis com as qualidades necessárias à durabilidade das relações sociais. O trabalhador flexível é, precisamente, aquele que está sempre disposto a se desvencilhar de antigos vínculos para se adaptar às mudanças. Um relacionamento durável, no entanto, se constrói sobre virtudes, como o compromisso 
mútuo a que se refere Sennett, que pressupõem a estabilidade dos vínculos pessoais. Essa contradição é especialmente grave no âmbito da família. Rico, um dos trabalhadores flexíveis que protagonizam a obra de Sennett, preocupa-se, justamente, com o tipo de valores que está transmitindo a seus filhos. Ele percebe como uma incoerência sua tentativa, que acredita ser sua missão na condição de pai, de ensinar a seus filhos o valor de virtudes duráveis como a lealdade, por exemplo, e de praticá-las no âmbito familiar, quando ele mesmo, um consultor que mudou de emprego e de cidade quatro vezes ao longo de sua vida profissional e que acredita no caráter positivo da mudança, sempre praticou, como trabalhador, os valores da flexibilidade. Os valores que, na concepção de Rico, devem informar os relacionamentos familiares não são os mesmos relacionados ao sucesso, ou mesmo à sobrevivência, no trabalho e, no seu diagnóstico, eles estão se perdendo. Rico diz que se sente um "idiota" quando fala em compromissos mútuos com seus filhos, já que sabe que para eles, trata-se de uma "virtude abstrata", que eles não veem mais em nenhuma parte (ibid., p. 26). Sennett oferece a dimensão do problema:

Esse conflito entre família e trabalho impõe algumas questões sobre a própria experiência adulta. Como se podem buscar objetivos de longo prazo numa sociedade de curto prazo? Como se podem manter relações sociais duráveis? Como pode o ser humano desenvolver uma narrativa de identidade e história de vida numa sociedade composta de episódios e fragmentos? As condições da nova economia alimentam, ao contrário, a experiência com a deriva no tempo, de lugar em lugar, de emprego em emprego. Se eu fosse explicar mais amplamente o dilema de Rico, diria que o capitalismo de curto prazo corrói o caráter dele, sobretudo aquelas qualidades de caráter que ligam os seres humanos uns aos outros, e dão a cada um deles um senso de identidade sustentável" (SENNETT, 2005, p. 27).

\subsubsection{A comunidade como refúgio contra a insegurança da modernidade reflexiva}

O aprofundamento dos processos de referencialidade interna da vida e de distanciamento do espaço e do tempo refletem-se, como visto, na forma como os indivíduos compreendem seu lugar no mundo. Ambos os processos têm em comum o fato de colocarem em xeque as bases sobre as quais as pessoas organizam suas vidas. ${ }^{3} \mathrm{~A}$

\footnotetext{
${ }^{3}$ Mais adiante, a relevância dos temas até o momento expostos, como, por exemplo, a perda da civilidade e a exposição da intimidade e dos sentimentos pessoais, a dinâmica das relações puras e a penetração da espiral de individualização na família, a mediação pela ficha simbólica do dinheiro e a peculiaridade das relações
} 
reflexividade que caracteriza a modernidade tardia, ao pressupor a contínua revisão de todos os aspectos do cotidiano, nelas inocula uma constante sensação de insegurança. De acordo com Bauman, a palavra "segurança" tem três sentidos distintos. O primeiro, que ele chama de "security" se refere à confiança do indivíduo na permanência e na estabilidade de suas condições de vida, isto é, à sensação de que tudo o que o indivíduo incorporou a seu repertório, em termos de bens, valores, conhecimentos, habilidades ou posições sociais, será preservado e manterá seu valor como um ferramental adequado a fazer frente aos desafios impostos pela vida. O segundo sentido, que Bauman chama de "certainty", alude à certeza a respeito da validade dos códigos de valores que orientam a tomada de decisões na vida cotidiana e que permitem distinguir entre uma boa e uma má estratégia de ação. $\mathrm{O}$ terceiro sentido, enfim, que Bauman chama de "safety", diz respeito à ausência de ameaças à vida e à integridade física do indivíduo, bem como ao ambiente em que vive e às pessoas com quem convive (BAUMAN, 1999, p. 17).

Conforme Bauman, embora todas as dimensões da segurança tenham sido recentemente abaladas, há uma certa "sobrecarga" da safety, já que para ela são canalizadas as inseguranças que têm origem em abalos acontecidos no âmbito da security e da certainty. Tudo se passa, segundo Bauman, como naquela anedota em que um homem procura uma moeda perdida perto de um poste de luz, embora não a tenha perdido naquele local, só porque ali é mais fácil de enxergar (ibid., p. 49). Com efeito, uma vez que a safety se refere a ameaças mais tangíveis e mais visíveis, a sensação de insegurança é geralmente identificada com a insegurança física vivenciada nas grandes cidades em razão da ocorrência de crimes violentos.

No entanto, a sensação de insegurança não se reduz à esfera da safety. Como reconhece Beck, "la clave de la seguridad en la vida reside en el mercado de trabajo" (BECK, 2006, p. 218). De fato, tanto a referencialidade interna da vida quanto o distanciamento do tempo e do espaço estão de alguma forma relacionados ao mundo do trabalho, seja ao fenômeno da transformação do trabalho em uma mercadoria, oferecida no mercado, que está por trás da dissolução dos vínculos tradicionais e do processo de individualização, seja, mais recentemente, à emergência do regime de acumulação flexível, descrita por Harvey e Sennett, que submete as práticas no trabalho à "revisão crônica"

entre estranhos, será evidenciada à medida que eles apareçam no decorrer da análise dos casos concretos estudados e interfiram no modo de proceder da Justiça Restaurativa. 
característica da reflexividade de Giddens, especialmente com o constante remanejamento de funções e a precariedade da situação de emprego, e inaugura uma nova escala de valores ao atribuir caráter positivo ao universo do efêmero, do volátil e do instantâneo. Essas mudanças no mundo do trabalho põem em xeque, especialmente, a security e a certainty, ameaçando a permanência das condições de vida do indivíduo e a vigência dos valores pelos quais ele costuma se pautar. Ademais, como vimos, a entrada da mulher no mercado de trabalho, como uma das portas à penetração da espiral da individualização no seio da família, também destitui a família de sua condição de refúgio da "economia moral" e, consequentemente, de seu papel estabilizador de garantia da securiry e da certainty.

A referencialidade interna da vida e o distanciamento do tempo e do espaço também afetam a confiança que os indivíduos depositam em seus relacionamentos sociais. De acordo com Giddens, confiança é a "crença na credibilidade de uma pessoa ou sistema" que "expressa uma fé na probidade (...) de um outro ou na correção de princípios abstratos" (GIDDENS, 1991, p. 41). A confiança, assim, envolve mais do que um cálculo de probabilidade, baseado na experiência, a respeito da concretização de certo evento - ela é um exercício de "fé" ou um ato de "crença". Ela é, por assim dizer, uma aposta, desprovida de um fundamento cognitivo sólido. De fato, ressalta Giddens que a confiança é essencial, justamente, em situações de falta de informação. É o caso, por exemplo, dos sistemas abstratos, sobre cujo funcionamento o indivíduo não tem pleno conhecimento. Ocorre, no entanto, que, enquanto a confiança em pessoas se funda na mutualidade da experiência existente entre elas, envolvendo certa proximidade, a confiança em sistemas abstratos se apóia em princípios impessoais e supõe, como vimos, o distanciamento espaço-temporal das partes. Nesse sentido, afirma Giddens que "esta situação cria novas formas de vulnerabilidade psicológica, e a confiança em sistemas abstratos não é tão gratificante como a confiança em pessoas o é" (ibid., p. 116). Mas, ainda de acordo com Giddens, mesmo a confiança entre as pessoas é debilitada no contexto da modernidade reflexiva. Em sociedades tradicionais, a confiança era estruturada em torno de códigos fixos de comportamento que determinavam a postura a ser assumida por cada uma das partes em seus relacionamentos pessoais. Nas sociedades modernas, diferentemente, a confiança não é um dado que emana de formas de conduta institucionalizadas, mas um projeto a ser "trabalhado" pelas partes, que requer a "abertura do indivíduo para o outro" diz Giddens que “onde ela não pode ser controlada por códigos normativos fixos, a 
confiança tem que ser ganha" (ibid., p. 123). A confiança, assim, é construída como parte do projeto reflexivo do "eu" que resulta da referencialidade interna da vida. A falta de amparo em referenciais externos, a exemplo do que ocorre em relação aos sistemas abstratos, também é causa de vulnerabilidade psicológica e desemboca em um tipo mais frágil de confiança.

Esse cenário de insegurança - ou de falta de confiança - leva à tentativa de se tomar as rédeas do carro de Jagrená. Essa tentativa está por trás da ideia de comunidade, que ressurge agora justamente fruto do desejo de se encontrar algo que contrabalance o aprofundamento do processo de individualização - que nos lembre que, por mais individualizados estejamos, ainda formamos parte de uma sociedade. De acordo com Giddens, a referencialidade interna da vida pode levar a uma sensação pessoal de falta de sentido, que desemboca no que ele chama de "retorno do recalcado" (GIDDENS, 2002, p. 187). Uma das tendências desse "retorno do recalcado" consiste no resgate de referenciais de vida externos, com a revalorização de instituições tradicionais, como a família ${ }^{4}$ e a religião, e a recuperação de formais tradicionais de vida, como aquelas relacionadas à vida em comunidade. "Comunidade", nas palavras de Bauman, “é, hoje, a última relíquia das utopias da boa sociedade de outrora; é o que sobra dos sonhos de uma vida melhor, compartilhada com vizinhos melhores, todos seguindo melhores regras de convívio" (BAUMAN, 2001, p. 108). A comunidade é uma "promessa de um porto seguro" (ibid., p. 196), que, ao evocar sensações de security, certainty e safety destronadas pela modernidade reflexiva, remete a um mundo que não nos está mais disponível, mas do qual desejamos nos reapossar (BAUMAN, 2007, p. 3). Daí o apelo que, recentemente, tem exercido a vida nas pequenas cidades ou em condomínios fechados.

A noção de comunidade também se equilibra na tensão entre "socialização" e “individualização". A comunidade "moderna", assim como a comunidade "tradicional", transmite ao indivíduo a mensagem de que ele é parte de um todo. Mas, diferentemente do que ocorre nas comunidades tradicionais, a adesão às comunidades modernas é voluntária. Ela é, por assim dizer, um produto da escolha do indivíduo. Nesse sentido, nada mais é do que um "estilo de vida", de acordo com a formulação de Giddens, que faz parte do projeto

\footnotetext{
${ }^{4}$ Em 2007, o Datafolha refez um levantamento sociocomportamental sobre a família brasileira que havia realizado, pela primeira vez, em 1998. Na pesquisa de 1998, 61\% dos entrevistados disseram considerar a família "muito importante". Em 2007, esse número aumentou para 69\%. Nas famílias com renda entre dez e vinte salários mínimos, esse índice é de 81\% (cf. o caderno Família Brasileira, publicado em 7 de outubro de 2007 pelo jornal "Folha de S. Paulo", p. 17).
} 
reflexivo do "eu", como mais um tijolo na construção da autoidentidade do indivíduo. Com efeito, a participação do indivíduo em uma comunidade de interesses, cujos seus membros compartilham gostos, atividades ou quaisquer outras características que tenham em comum, é um dos elementos em torno dos quais o indivíduo, na modernidade reflexiva, estrutura sua identidade - tendo em vista, especialmente, a perda da centralidade da profissão como elemento estruturante da identidade, tal qual apontado por Sennett. O pertencimento a uma "tribo", hoje, desempenha um papel chave na autodefinição do indivíduo. Ocorre, no entanto, que a comunidade tradicional, fundada na Wesenwille, se estrutura em torno de um entendimento tácito, que não sobrevive à reflexão que está embutida na escolha. Por assim dizer, quando uma comunidade é produto da Kürwille, tendo consciência de si mesma, ela deixa de ser propriamente uma comunidade (BAUMAN, 2007, p. 11).

Isso demonstra que a comunidade moderna não é uma comunhão de vida, como a comunidade tradicional, mas uma mera comunidade de interesses. Nesse sentido, as relações levadas a cabo no interior da comunidade pouco diferem das relações com estranhos: elas também tendem a ser episódicas e a durar somente enquanto durarem os interesses em comum. É por isso que Bauman chama as comunidades modernas de “cloakroom communities” ou, numa tradução livre, comunidades de chapelaria. Trata-se de comunidades que se mobilizam em torno de alguma situação - um "espetáculo", na alegoria de Bauman -, na qual algumas circunstâncias que indivíduos diferentes têm em comum vêm à tona, enquanto outros interesses, que os separam, "são temporariamente postos de lado, deixados em fogo brando ou inteiramente silenciados" (BAUMAN, 2001, p. 228). Nas palavras de Bauman, são comunidades "explosivas", que tendem a ser voláteis, precárias e voltadas a um "propósito único" e, ao mesmo tempo, emocionalmente carregadas e cheias de "som e fúria":

O termo 'cloakroom community' capta bem alguns de seus traços característicos. Os frequentadores de um espetáculo se vestem para a ocasião, obedecendo a um código distinto do que seguem diariamente - o ato que simultaneamente separa a visita como uma 'ocasião especial' e faz com que os frequentadores pareçam, enquanto durar o evento, mais uniformes do que na vida fora do teatro. É a apresentação noturna que leva todos ao lugar - por diferentes que sejam seus interesses e passatempos durante o dia. Antes de entrar no auditório, deixam os sobretudos ou capas que vestiram nas ruas no cloakroom da casa de espetáculos (contando o número de cabides usados pode-se julgar quão 
cheia está a casa e quão garantido está o futuro imediato da produção). Durante a apresentação, todos os olhos estão no palco; e também a atenção de todos. Alegria e tristeza, risos e silêncios, ondas de aplauso, gritos de aprovação e exclamações de surpresa são sincronizados - como se cuidadosamente planejados ou dirigidos. Depois que as cortinas se fecham, porém, os espectadores recolhem seus pertences do cloakroom e, ao vestirem suas roupas de rua outra vez, retornam a seus papéis mundanos, ordinários e diferentes, dissolvendo-se poucos momentos depois na variada multidão que enche as ruas da cidade e da qual haviam emergido algumas horas antes (BAUMAN, 2001, p. 228).

Bauman também designa as cloakroom communities de "comunidades de carnaval". As comunidades de carnaval são "eventos" que, como as festas de carnaval, "liberam pressão e permitem que os foliões suportem melhor a rotina a que devem retornar no momento em que a brincadeira acabar", quando encontrarão tudo exatamente como estava antes (ibid., p. 229). Nesse sentido, as cloakroom communities e as comunidades de carnaval têm, muitas vezes, efeito contrário ao que pretendem: dispersam, ao invés de condensar, as energias de sociabilidade, deixando os indivíduos tão isolados quanto antes e dificultando sua mobilização em torno de um projeto coletivo realmente "genuíno" e duradouro (ibid., p. 230).

As cloakroom communities e as comunidades de carnaval revelam, assim, uma dificuldade de conciliar "socialização" e “individualização". Nelas, o prato da "individualização" sempre acaba pesando mais na balança. No entanto, a insegurança que assombra a modernidade reflexiva pode levar a comunidades em que se exagera, ao contrário, o componente de "socialização". Sennett chama a atenção para as "comunidades destrutivas", cujo surgimento relaciona a seu diagnóstico de declínio da vida pública. Comunidades destrutivas, de acordo com Sennett, são aquelas em que os indivíduos não compartilham ações, mas um "estado" (SENNETT, 1988, p. 295). A exemplo da cloakroom community, a comunidade destrutiva não consiste em uma "comunhão de vida" à moda da Gemeinschaft de Tönnies, mas em uma comunhão emocional de sentimentos e intimidades. Elas traduzem uma tentativa de construção comum da identidade cujo produto é uma "personalidade coletiva" que tende a anular a individualidade e a rechaçar a heterogeneidade. Bauman, citando Lévi-Strauss, lembra que existem duas estratégias para se lidar com a alteridade: a estratégia antropofágica, que assimila a diferença, e a estratégia antropoêmica, que expele a diferença (BAUMAN, 2001, p. 118). A comunidade destrutiva vale-se claramente de uma tática antropoêmica que reforça a própria homogeneidade por 
meio da negação, da desqualificação, da expulsão e - em última instância - da destruição do diferente. São exemplos de comunidades destrutivas algumas daquelas que, atualmente, se articulam em torno de fundamentalismos religiosos e de nacionalismos étnicos com viés xenófobo. O grande problema dessas comunidades, segundo Bauman, reside em que, quanto mais elas se fecham em si mesmas, maior a insegurança que sentem diante do "outro".

Qualquer que seja a forma que assuma, o comunitarismo atual não é uma mera relíquia do passado ou, como afirma Bauman, "um soluço de instintos ou inclinações ainda não inteiramente erradicados que o progresso da modernização mais cedo ou mais tarde vai neutralizar ou diluir" (ibid., p. 125). Como uma resposta, satisfatória ou não, à sensação de insegurança, ele pode ser encarado como uma reação à tendência centrífuga do processo de individualização. Trata-se de um esforço para metamorfosear relações distanciadas em relações de proximidade, que se traduz na criação de situações, ainda que momentâneas, de intimidade, por meio da personalização de contatos impessoais. É esse mesmo esforço que parece subjazer à dinâmica da Justiça Restaurativa e ao apelo, por ela evocado, da comunidade. Uma vez, contudo, que a Justiça Restaurativa se reduza a um simples reflexo do chamado "retorno do recalcado", suas potencialidades estarão, desde logo, cerceadas: da mesma forma que o ideal comunitário coloca em evidência os excessos desarranjadores da radicalização reflexiva do processo de modernização, mas, em vista de seu caráter regressivo, é incapaz de detê-lo, uma Justiça Restaurativa que sobre esse mesmo ideal esteja assentada, embora bem se preste a revelar as imperfeições do sistema de justiça criminal tradicional, será incapaz de transformá-lo. As limitações de um modelo de Justiça Restaurativa pautado por esses parâmetros serão analisadas, concretamente, a seguir. 


\section{A Justiça Restaurativa em ação}

\subsection{Origem e formulação da Justiça Restaurativa}

\subsubsection{Desenvolvimento prático e marco normativo internacional}

Em 1974, dois jovens da cidade de Elmira, localizada na província de Ontário, no Canadá, foram acusados de praticar atos de vandalismo contra vinte e duas propriedades. $\mathrm{O}$ caso foi amplamente divulgado na região e chegou ao conhecimento do oficial de probation Mark Yantzi, membro do Comitê Central Menonita da cidade de Kitchener, também em Ontário, que estava engajado, junto a um grupo de cristãos, na busca de alternativas na reação a pequenos delitos. Esse oficial, com o apoio de outro membro do Comitê, Dave Worth, propôs ao juiz do caso que promovesse um encontro entre os dois jovens e suas vítimas, o que foi determinado pelo juiz quando do proferimento da sentença. $\mathrm{O}$ encontro foi realizado e resultou em um acordo de restituição; depois de alguns meses as vítimas foram ressarcidas de todos os danos (ZEHR, 1995, p. 158-9).

A partir dessa experiência, outros programas de reconciliação entre vítima e ofensor (os chamados VORPs - Victim Offender Reconciliation Programmes) foram estruturados no Canadá, o que foi impulsionado pela "vivificação de práticas de solução de conflitos indígenas" (FROESTAD-SHEARING, 2005, p. 82). Nos Estados Unidos, as primeiras experiências ocorreram entre 1977 e 1978, na cidade de Elkhart, no Estado de Indiana. Foi também em 1977, quando várias iniciativas já se disseminavam, que o psicólogo Albert Eglash cunhou a expressão Justiça Restaurativa, no seu texto Beyond Restitution: Creative Restitution (ROLIM, 2004). Nesse trabalho, Eglash, fundado na ideia de restituição criativa que já vinha discutindo desde no final dos anos cinquenta, sugeriu que estimular o ofensor a pedir perdão pelos seus atos poderia ser um mecanismo apto a promover a sua reabilitação (JACCOUD, 2005).

Foi em 1989, no entanto, que os lineamentos da Justiça Restaurativa ganharam dimensão significativa. Com base nos mecanismos de solução de conflitos próprios da cultura maori, a Nova Zelândia promulgou o Children, Young Persons and Their Families Act (PINTO, 2004), reformulando radicalmente seu sistema de justiça da infância e da juventude. Desde então, a maior parte dos casos envolvendo atos infracionais cometidos 
por crianças ou adolescentes são solucionados informalmente pela própria polícia, que, em havendo necessidade, indica a realização de uma Family Group Conference (FGC), na qual o infrator, na presença de sua família, busca uma conciliação com a vítima. Somente excepcionalmente os casos são encaminhados ao juízo comum. O sucesso dessa reforma levou o governo neozelandês a fomentar, a partir de 1995 programas restaurativos também no sistema de justiça criminal adulto. ${ }^{5}$

As inúmeras experiências surgidas nas décadas de oitenta e noventa fizeram que a temática da Justiça Restaurativa chegasse até a Organização das Nações Unidas. Depois da realização do Décimo Congresso das Nações Unidas para Prevenção do Crime Tratamento do Delinquente, em abril de 2000, cujo resultado foi a Vienna Declaration on Crime and Justice: Meeting Challenges of the Twenty-first Century, na qual se conclamou a adoção de mecanismos restaurativos de solução de conflitos penais, os governos do Canadá e da Itália submeteram à Comissão de Prevenção do Crime e Tratamento do Delinquente uma resolução, propondo que as Nações Unidas desenvolvessem diretrizes internacionais para a incorporação de programas de Justiça Restaurativa. Essa resolução propunha que fosse circulado o esboço de uma declaração sobre princípios básicos de Justiça Restaurativa entre os membros da organização, de modo que comentários e sugestões pudessem ser feitos. Depois da intervenção de trinta e sete países, oito organizações não-governamentais e algumas entidades da própria ONU, foi realizada no Canadá, em 2001, uma reunião com um grupo de dezoito experts de dezesseis diferentes países e oito observadores. O chamado Grupo de Ottawa preparou um documento no qual procurou padronizar alguns entendimentos sobre a Justiça Restaurativa, sem, no entanto, apegar-se a definiçõos muito rígidas e sem impor caráter obrigatório a suas prescrições, eis que essas atitudes poderiam inibir o desenvolvimento natural do movimento restaurativo. O relatório da reunião e a Declaração de Princípios Básicos de Justiça Restaurativa elaborada pelo Grupo de Ottawa foram submetidos à Comissão de Prevenção do Crime e Tratamento do Delinquente, que recomendou a adoção do documento pelo Conselho Econômico e Social (ECOSOC). Assim, em agosto de 2002, o Conselho Econômico e Social emitiu em uma de suas

\footnotetext{
${ }^{5}$ Para maiores informações sobre a implementação e o funcionamento da Justiça Restaurativa na Nova Zelândia, cf. a obra de Gabrielle Maxwell (MAXWELL, 2005).
} 
resoluções os Basic principles on the use of restorative justice programmes in criminal matters. $^{6}$

Os programas de Justiça Restaurativa foram definidos pelo ECOSOC como aqueles programas que, valendo-se de processos restaurativos, atinjam resultados restaurativos. É considerado "processo restaurativo" qualquer procedimento em que a vítima e o ofensor, além, quando apropriado, de indivíduos outros como familiares ou membros da comunidade, participam juntos e ativamente, por meio de mecanismos de conciliação, na solução dos problemas suscitados pela prática do crime, dispondo, geralmente, da ajuda de um facilitador. O "resultado restaurativo", por sua vez, é o acordo alcançado ao fim de um processo restaurativo, abrangendo soluções como a reparação, a restituição e a prestação de serviços à comunidade, destinadas a responder às necessidades e às responsabilidades individuais e coletivas e centradas na reintegração social da vítima e do ofensor. Além do intuito de estipular definições fluidas, mas claras, é patente na resolução do Conselho uma grande preocupação em conciliar programas restaurativos com a preservação do devido processo legal, fazendo menção a garantias processuais como a presunção de inocência e ao acesso do Poder Judiciário e ressaltando sempre a voluntariedade da participação da vítima e do ofensor.

\subsubsection{Perspectivas teóricas e a noção de comunidade}

Considera-se como marco teórico do desenvolvimento da Justiça o lançamento, em 1990, da obra de Howard Zehr, intitulada Changing lenses: a new focus for crime and justice, em que ele sugeria, animado pela mesma perspectiva religiosa que esteve presente na origem prática da Justiça Restaurativa, que o crime fosse encarado não mais como uma infração estatal, mas como um acontecimento que abala relações e causa prejuízos a indivíduos e à comunidade. Sua proposta, ancorada na ideia bíblica de "all rightness" expressa na palavra hebraica shalom (ZEHR, 1995, p. 130), era a de fazer da justiça um meio de "make things right", isto é, de corrigir situações consideradas erradas. A consequência dessa nova visão seria, de acordo com ele, uma mudança na resposta

\footnotetext{
${ }^{6}$ Tais relatos e outras informações podem ser encontradas no website www.restorativejustice.org. A resolução do Conselho Econômico e Social das Nações Unidas na qual foram adotados os Basic principles on the use of restorative justice programmes in criminal matters encontra-se anexada.
} 
reservada ao crime, trocando-se a punição pela busca da restauração das relações afetadas pela prática do crime e da reparação dos danos causados. ${ }^{7}$

Apoiadas no argumento inaugurado por Zehr, duas concepções formaram-se a respeito da Justiça Restaurativa: uma concepção minimalista e uma concepção maximalista (JACCOUD, 2005). A concepção minimalista dá ênfase ao processo da Justiça Restaurativa, defendendo que o que confere caráter restaurativo a um procedimento é a forma pela qual o processo é levado a cabo, permitindo a participação de todos os afetados pelo crime, não importando tanto o resultado atingido. Assim, a concepção minimalista define a Justiça Restaurativa como:

a process whereby all the parties with a stake in a particular offence come together to resolve collectively how to deal with the aftermath of the offence and its implications for the future (MARSHALL, 1999, p. 5). ${ }^{8}$

A concepção maximalista, por sua vez, confere maior ênfase aos resultados, conferindo natureza restaurativa somente a procedimentos que levarem a resultados afins à reparação do dano. Desse modo, a Justiça Restaurativa, na concepção maximalista, é definida como:

every action that is primarily oriented towards doing justice by restoring the harm that has been caused by a crime" (BAZEMORE; WALGRAVE, 1999, p. 48). ${ }^{9}$

Os detratores da concepção minimalista a acusam de exercer impacto inexpressivo sobre a justiça penal tradicional, já que ela propõe um procedimento que é simplesmente agregado ao procedimento comum, mantido inalterado, e que pode levar a resultados punitivos. Isso não ocorreria se adotada a concepção maximalista, pois, segundo ela, é possível que a reparação do dano seja resultado de qualquer tipo de procedimento - pode, por exemplo, ser imposta em uma sentença. Por outro lado, ela é reprovada por abdicar da

\footnotetext{
${ }^{7}$ Não se pretende, aqui, transmitir a impressão de que é a inspiração religiosa ou ritual que desqualifica a Justiça Restaurativa como uma alternativa ao fazer justiça. Essa origem é apenas um indício de que o ideal restaurativo está ancorado em uma forma de sociabilidade - que identificamos como comunidade - cujo espaço é cada vez menor no contexto da modernidade.

${ }^{8}$ Tradução livre: "um processo pelo qual todas as partes com um interesse em uma ofensa em particular se reúnem para resolver coletivamente como lidar com as consequências da ofensa e com suas implicações para o futuro".

9 Tradução livre: "toda ação que é primariamente orientada na direção de fazer justiça por meio da restauração do dano que tenha sido causado pelo crime".
} 
dimensão participativa da Justiça Restaurativa, conformando-se com o procedimento judicial tradicional desde que seu desfecho consista em alguma forma de reparação.

Não obstante a polêmica entre essas duas concepções, poucos são os trabalhos que, realmente, avançam na teorização da Justiça Restaurativa. A maior parte deles limita-se a descrever experiências pontuais ou a fazer uma apologia militante da implementação da Justiça Restaurativa, listando seus benefícios em comparação ao modelo de justiça criminal tradicional, que chamam de Justiça Retributiva. Na dificuldade de estabelecer elementos comuns entre as diversas experiências, a Justiça Restaurativa é definida, não raro, negativamente, isto é, suas diretrizes são derivadas da subversão das características do sistema de justiça tradicional, chamado de "justiça retributiva", obtendo-se uma diferenciação construída a partir da oposição frontal entre os dois modelos:

\section{QUADRO 1: Justiça Retributiva e Justiça Restaurativa: pressupostos}

Fonte: adaptação de quadro criado por Pedro Scuro Neto (SCURO NETO, 2004)

\begin{tabular}{|l|l|}
\hline JUSTIÇA RETRIBUTIVA & JUSTIÇA RESTAURATIVA \\
\hline $\begin{array}{l}\text { Infração: noção abstrata, } \\
\text { violação da lei, ato contra o Estado. }\end{array}$ & $\begin{array}{l}\text { Infração: ato contra pessoas, grupos e } \\
\text { comunidades. }\end{array}$ \\
\hline $\begin{array}{l}\text { Controle: Justiça penal } \\
\text { multa ou cumprir pena. }\end{array}$ & $\begin{array}{l}\text { Controle: Justiça, atores, comunidade. } \\
\text { responsabilidades e compensar o dano. }\end{array}$ \\
\hline $\begin{array}{l}\text { Comproção: ato e responsabilidade } \\
\text { exclusivamente individuais. }\end{array}$ & $\begin{array}{l}\text { Infração: ato e responsabilidade com } \\
\text { dimensões individuais e sociais. }\end{array}$ \\
\hline $\begin{array}{l}\text { Pena eficaz: a ameaça de castigo } \\
\text { altera condutas e coíbe a } \\
\text { criminalidade. }\end{array}$ & $\begin{array}{l}\text { Castigo somente não muda condutas além } \\
\text { de prejudicar a harmonia social e a } \\
\text { qualidade dos relacionamentos. }\end{array}$ \\
\hline
\end{tabular}




\begin{tabular}{|c|c|}
\hline $\begin{array}{l}\text { Vítima: elemento periférico no } \\
\text { processo legal. }\end{array}$ & $\begin{array}{l}\text { Vítima: vital para o encaminhamento } \\
\text { do processo judicial e a solução } \\
\text { de conflitos. }\end{array}$ \\
\hline $\begin{array}{l}\text { Infrator: definido em termos de suas } \\
\text { deficiências. }\end{array}$ & $\begin{array}{l}\text { Infrator: definido por sua capacidade } \\
\text { de reparar danos. }\end{array}$ \\
\hline $\begin{array}{l}\text { Preocupação principal: estabelecer culpa } \\
\text { por eventos passados (Você fez ou não } \\
\text { fez?). }\end{array}$ & $\begin{array}{l}\text { Preocupação principal: resolver o conflito, } \\
\text { enfatizando deveres e obrigações futuras. } \\
\text { (O que precisa ser feito agora?). }\end{array}$ \\
\hline $\begin{array}{l}\text { Ênfase: relações formais, adversativas, } \\
\text { adjudicatórias e dispositivas. }\end{array}$ & Ênfase: diálogo e negociação. \\
\hline $\begin{array}{l}\text { Fim: impor sofrimento para punir } \\
\text { e coibir. }\end{array}$ & $\begin{array}{l}\text { Fim: restituir para compensar as } \\
\text { partes e reconciliar. }\end{array}$ \\
\hline $\begin{array}{l}\text { Comunidade: marginalizada, representada } \\
\text { pelo Estado }\end{array}$ & $\begin{array}{l}\text { Comunidade: viabiliza o processo } \\
\text { restaurativo. }\end{array}$ \\
\hline
\end{tabular}

As diferenças reunidas no quadro acima, que sintetizam a contraposição frequentemente encontrada nos textos que versam sobre o tema da Justiça Restaurativa, referem-se, sobretudo, a divergências de ordem filosófica entre os modelos restaurativo e retributivo, enfatizando o sentido que cada um deles confere aos diversos elementos implicados no sistema de justiça criminal. No que diz respeito, especificamente, ao procedimento por meio do qual se efetiva cada um dos modelos, as diferenças podem ser resumidas em quatro pontos: 


\section{QUADRO 2: Justiça Retributiva e Justiça Restaurativa: procedimento}

Fonte: elaborado a partir de texto de Joanna Shapland (SHAPLAND, 2003)

\begin{tabular}{|c|c|c|}
\hline Pontos & Justiça Retributiva & Justiça Restaurativa \\
\hline 1. Presença do Estado & $\begin{array}{c}\text { Obrigatoriedade do } \\
\text { procedimento judicial }\end{array}$ & $\begin{array}{l}\text { Liberdade de entrada e de } \\
\text { saída no procedimento } \\
\text { restaurativo }\end{array}$ \\
\hline $\begin{array}{l}\text { 2. Presença do } \\
\text { Promotor de Justiça } \\
\text { e do Juiz de Direito }\end{array}$ & $\begin{array}{l}\text { Presença do promotor e do } \\
\text { juiz como baliza na } \\
\text { definição da matéria de } \\
\text { conhecimento: restrição da } \\
\text { apreciação judicial a } \\
\text { questões estritamente } \\
\text { relacionadas ao crime. }\end{array}$ & $\begin{array}{l}\text { Ausência do promotor e do } \\
\text { juiz ampliam a matéria em } \\
\text { discussão, extrapolando os } \\
\text { limites dos fatos } \\
\text { estritamente relacionados ao } \\
\text { crime. }\end{array}$ \\
\hline $\begin{array}{l}\text { 3. Presença da } \\
\text { comunidade }\end{array}$ & $\begin{array}{l}\text { Subjugação de poderes } \\
\text { locais pela justiça estatal }\end{array}$ & $\begin{array}{c}\text { Abertura para a participação } \\
\text { ativa de representantes da } \\
\text { comunidade }\end{array}$ \\
\hline 4. Papel dos advogados & Postura adversarial & $\begin{array}{l}\text { Postura cooperativa, com } \\
\text { ênfase na proteção dos } \\
\text { direitos humanos }\end{array}$ \\
\hline
\end{tabular}

Embora, como ressaltado por Roger Matthews (MATTHEWS, 2006), a construção de uma relação dicotômica entre a Justiça Restaurativa e uma justiça que seria essencialmente retributiva sirva às vezes para escamotear o fato de que a Justiça Restaurativa tem muito mais em comum com a chamada Justiça Retributiva do que se gostaria de admitir, a maior parte dos textos sobre a Justiça Restaurativa limita-se, realmente, a evocar suas vantajosas diferenças em relação ao sistema de justiça criminal tradicional. Há alguns autores, no entanto, que se preocupam em oferecer uma fundamentação mais sólida ao modelo restaurativo e que, para isso, não se satisfazem com a simples comparação, mas buscam construir conceitos capazes de sustentar a proposta restaurativa.. Destaca-se, nesse sentido, o trabalho do autor australiano John Braithwaite, 
que alicerça a Justiça Restaurativa sobre dois conceitos: a vergonha reintegrativa e a regulação responsiva. Na obra Crime, shame and reintegration (BRAITHWAITE, 1999), ele enxerga a vergonha como um potente instrumento de coibição do crime. Acredita que, após a prática de qualquer crime, a comunidade em que o ofensor está inserido se incumbe de inculcar-lhe um sentimento de vergonha. Essa vergonha, de acordo com Braithwaite, pode ser desintegrativa, se implicar a marginalização do ofensor, com a introjeção de uma nova identidade e o aprofundamento de seu envolvimento com o crime - como diagnosticado, no campo da criminologia, pelos teóricos do chamado labelling approach, também conhecido como teoria da rotulação social -, ou reintegrativa, quando a reprovação do ato é acompanhada de esforços de reaceitação do indivíduo pela comunidade. A Justiça Restaurativa seria, nesse contexto, um mecanismo de vergonha reintegrativa, que, ao mesmo tempo reprovaria e readmitiria o indivíduo no seio de sua comunidade.

No entanto, o próprio Braithwaite ressalva que sua teoria sobre a vergonha reintegrativa só se aplica em relação a crimes que ele chama de predatórios, isto é, aqueles em que uma pessoa toma outra como sua presa, geralmente identificados com os crimes contra a vida e a propriedade, em torno de cuja reprovabilidade existe grande consenso social. Isso porque a imposição de vergonha pela comunidade e a sua efetividade sobre o indivíduo só se dão quando a reprovação da conduta praticada está amplamente sedimentada socialmente - do contrário, sem esse consenso, não haverá reprovação e, portanto, não haverá vergonha. $\mathrm{O}$ consenso, assim, é a noção-chave que sustenta todo o edifício teórico de Braithwaite. Além de vislumbrar na vergonha um efeito positivo que não é cogitado pelo labelling approach, Braithwaite também se afasta da teoria da rotulação social por não julgar que o crime seja simplesmente um rótulo que se atribui, pelas instâncias de controle social, a uma gama diversa de condutas. Defende que, por mais arbitrário que possa parecer o processo de etiquetamento de comportamentos sociais, o fato é que o sujeito age sabendo que sua conduta será rotulada como crime. Para ele, "it is the defiant nature of the choice that distinguishes it [the criminal choice] from other social actions" (BRAITHWAITE, 1999, p. 2) ${ }^{10}$. De acordo com o australiano, então, existe uma certa homogeneidade nas várias condutas definidas como crime, que reside no fato de que

${ }^{10}$ Tradução livre: "é a natureza desafiante da escolha que a distingue [a escolha criminal] de outras ações sociais". 
as escolhas são feitas pelo ator no conhecimento de que ele está desafiando uma prescrição penal e de que sua conduta é entendida socialmente como criminosa. Esse conhecimento, que unifica a variada gama de comportamentos criminosos, decorre da existência de um consenso social sobre o caráter criminoso dessas condutas.

O outro eixo em que se apoia a Justiça Restaurativa de John Braithwaite, ao lado da noção de vergonha reintegrativa, é a ideia de regulação responsiva, desenvolvida na obra Restorative Justice and Responsive Regulation (BRAITHWAITE, 2002). Valendo-se da ideia de "responsividade", palavra que, no idioma inglês, denota uma maior flexibilidade na reação ao delito, o australiano questiona a existência de respostas pré-determinadas aos crimes, sugerindo que seja possível ao Estado modular a intensidade de suas respostas conforme a necessidade no caso concreto. Monta assim, uma pirâmide regulatória, na qual retrata os três níveis de intervenção possíveis, em um contínuo que vai da reação menos interventiva à mais interventiva. Na base da pirâmide encontra-se a persuasão, o nível menos interventivo, no qual se preferem soluções negociadas. Depois, há o nível da dissuasão, no qual entra em cena a coerção estatal para a imposição de medidas mais incisivas, como sanções de natureza civil e administrativa, além de sanções penais não privativas de liberdade. Por fim, no cume da pirâmide, está o nível da incapacitação, em que se encontram sanções como a prisão e a cassação de licenças. Só se deve subir ao nível superior da pirâmide se não houve sucesso no nível inferior, evitando-se o desperdício de recursos materiais e simbólicos na eventualidade de êxito de uma resposta mais moderada. A Justiça Restaurativa, nesse esquema, ocuparia lugar no nível da persuasão.

Por maior que seja a diversidade entre trabalhos que versam sobre o tema a Justiça Restaurativa no que tange, especialmente, à sua profundidade teórica, todos eles têm em comum o fato de vislumbrarem a Justiça Restaurativa não apenas como um mero procedimento ou como um simples resultado de caráter reparador. As divergências entre as concepções maximalista e minimalista que cindem os autores são pequenas diante da grande convergência que os une, independentemente do modo como pretendem fundamentar ou operacionalizar a Justiça Restaurativa. Todos tendem a concebê-la como uma filosofia de vida, sob perspectiva holística (BRAITHWAITE, 2003) que a encara como um novo paradigma capaz de transformar não só o modo como funciona a justiça criminal, mas também a maneira como as pessoas se comportam e se relacionam em diversos âmbitos de suas existências: 


\begin{abstract}
A hallmark of restorative justice must be ongoing transformation: transformation of perspective, transformation of structures, transformation of people. It begins with transformation of ourselves, for we too have recompense to pay, reconciliation to seek, forgiveness to ask, and healing to receive. We look not only for justice "out there", but must turn the lens on ourselves as well - on our daily patterns of life and on our treatment of and attitudes towards others. Restorative justice is an invitation to renewal in communities and individuals as well as procedures and programs. Transformation of the world begins with transformation of ourselves (VAN NESS; STRONG, 2002, p. 249). ${ }^{11}$
\end{abstract}

Essa ambiciosa pretensão de vários dos teóricos da Justiça Restaurativa se relaciona com o fato de que, como apontado por Annalise Acorn, uma das mais enfáticas críticas do modelo restaurativo, a Justiça Restaurativa foi erigida sobre uma teoria da justiça que, animada por uma ética religiosa cristã - ou, nas palavras de John Pratt, por um "fervor evangélico" (PRATT, 2006) -, identifica na compaixão o cerne do fazer justiça (ACORN, 2004). De acordo com ela, precisamente porque seu leitmotiv é o exercício da compaixão, a Justiça Restaurativa opera mobilizando as emoções dos envolvidos na prática do delito. Daí porque grande parte dos trabalhos que advogam a Justiça Restaurativa optem, na apresentação do modelo, pela estratégia de suscitar a empatia do leitor por meio da narrativa de histórias reais bem-sucedidas de casos resolvidos pelo método restaurativo ou, simplesmente, contentem-se em levar a cabo uma defesa apaixonada e pouco refletida da Justiça Restaurativa. A exposição da Justiça Restaurativa, nesses termos, evoca um desejo por uma vida idílica, em que os conflitos interpessoais podem dar lugar a uma ideia de paz confundida com a de um consenso construído por meio da expressão dos sentimentos. Essa é a razão pela qual a noção de comunidade é descrita como "central" no pensamento restaurativo (WALGRAVE, 2002): a comunidade é pensada como um espaço seguro em que a intimidade das emoções pode ser revelada e partilhada e no qual a compreensão pode ser conquistada. Se a sociedade, como sugere Tönnies, é o lugar do cálculo frio e racional,

\footnotetext{
${ }^{11}$ Tradução livre: "A marca da Justiça Restaurativa deve ser uma contínua transformação: transformação de perspectiva, transformação de estruturas, transformação de pessoas. Ela começa com a transformação de nós mesmos, uma vez que nós também temos dívidas a pagar, reconciliação a buscar, perdão a pedir e cura a receber. Nós não buscamos justiça somente 'lá fora', mas devemos voltar as lentes sobre nós mesmos também - nos nossos padrões de vida cotidianos e sobre nosso tratamento e atitudes em relação aos outros. A Justiça Restaurativa é um convite à renovação de comunidades e indivíduos, assim como de procedimentos e programas. A transformação do mundo começa com a transformação de nós próprios".
} 
é a comunidade, para os restaurativistas, o espaço apropriado em que podem florescer os sentimentos, especialmente uma sensação de vinculação:

What is community? Community is a feeling, a perception of connectedness both to other individual human beings and to a group. Building community, then, involves building bonds between human beings. Where there is no perception of connectedness among a group of people, there is no community (McCOLD; WACHTEL, 2003, p. 295). ${ }^{12}$

A ideia de comunidade é referida pelos restaurativistas de forma geralmente imprecisa, como um contraponto ao Estado. À distância da justiça estatal é oposta a proximidade promovida pela abertura da Justiça Restaurativa ao envolvimento da comunidade. A proximidade é, justamente, o atributo que caracteriza a noção de comunidade nos trabalhos de autores, nos quais ela é frequentemente identificada com o conceito de commnunity of concern, ou "comunidade de relação", composta por

aquelas pessoas nas suas vidas [da vítima e do autor] que mais se preocupam com ambos (...), ou seja, aquelas pessoas mais diretamente relacionadas com o ofensor e com a vítima (familiares, amigos, vizinhos) e que, de alguma forma, podem dimensionar os efeitos ou foram afetadas pelo crime e [podem] colaborar para uma solução consensual (SICA, 2007, pp. 13-14).

A comunidade, então, é o grupo de pessoas com quem se mantém uma relação de proximidade, ou com quem se tem um certo grau de intimidade, em contraste com a impessoalidade imperante no restante da sociedade. Quando se estende a noção de comunidade para além desse círculo de conhecidos, o conceito perde precisão, passando a aludir, genericamente, à localidade em que residem autor e vítima, por exemplo. Nesse caso:

a proposta da Justiça Restaurativa é, justamente, reavivar as relações comunitárias, aproveitando-se da inevitável oportunidade que surge de cada conflito para criar novos espaços de transparência e acesso para o sistema de justiça e construir uma comunidade em lugar da insegurança (ibid., p. 14 ).

\footnotetext{
${ }^{12}$ Tradução livre: "O que é comunidade? Comunidade é um sentimento, uma percepção de conexão conexão pessoal em relação tanto a outros indivíduos quanto a um grupo. Construir uma comunidade implica, então, construir laços entre seres humanos. Onde não há percepção de conexão em um grupo de pessoas, não há comunidade".
} 
Mesmo alguns dos teóricos da Justiça Restaurativa, como Lode Walgrave, reconhecem a dificuldade de se definir o conceito de comunidade. De acordo com Walgrave, trata-se de uma noção problemática, porque constitui, mais propriamente, um vínculo psicológico entre pessoas do que uma entidade real e porque nela está contido o germe da intolerância que exclui e discrimina aqueles que não fazem parte dela. Por esse motivo, Walgrave prefere não usar o termo comunidade, mas simplesmente aludir àquilo que ele representa: a comunidade é encarada como "a container for ethics and social values and the ethics and values must be unpacked from ther container "13 ou como uma palavra que encerra "an ideal of justice in an utopian ideal of society" (WALGRAVE, 2004, p. 69). Comunidade, é então, uma noção que traduz um ideal de sociedade. Começando pela reforma do sistema de justiça, a Justiça Restaurativa pretende, assim, reformar a sociedade, de modo que ela se aproxime de um ideal expresso na noção de comunidade. Resta saber se a Justiça Restaurativa é realmente capaz de fazê-lo.

\subsection{Desenvolvimento da Justiça Restaurativa no Brasil}

Se as experiências pioneiras de Justiça Restaurativa, no exterior, datam da década de setenta, as primeiras iniciativas implementadas no Brasil são bem mais recentes, remontando a apenas dez anos atrás. As práticas inspiradas na filosofia restaurativa penetraram, inicialmente, nas escolas, como uma estratégia de solução de problemas disciplinares. Pedro Scuro Neto apresenta como marco da introdução da Justiça Restaurativa no país o chamado "Projeto Jundiaí", surgido em 1998, que resultou de uma pesquisa dedicada a identificar mecanismos efetivos de prevenção da violência em escolas públicas e que incorporou a realização de câmaras restaurativas na resolução de conflitos ocorridos no ambiente escolar (SCURO NETO, 2008).

O grande impulso à Justiça Restaurativa, no entanto, foi dado pelo Ministério da Justiça alguns anos depois, com a criação, em 2003, da Secretaria da Reforma do Judiciário. A reforma do Poder Judiciário, assumida como prioridade pelo governo, foi concebida como uma tentativa de equacionar o descompasso existente entre a atuação do Poder Judiciário e a nova realidade socioeconômica do país, delineada a partir da

13 Tradução livre: "um recipiente para a ética e para valores sociais e a ética e os valores têm de ser desembrulhados desse recipiente" (...) "um ideal de justiça em um ideal utópico de sociedade". 
redemocratização. Essa discrepância se expressa na tensão existente entre as mudanças quantitativas e qualitativas sofridas pela demanda judiciária nos últimos anos e a insatisfatória capacidade de resposta do Poder Judiciário. De um lado, a redemocratização do país aprofundou no Brasil uma tendência, de caráter global, de judicialização da política e das relações sociais. ${ }^{14}$ De acordo com Maria Tereza Sadek, fatores como a forma de governo presidencialista (por favorecer o antagonismo entre Poder Executivo e Poder Executivo) e a ampliação do rol de legitimados para a propositura de ações diretas de inconstitucionalidade (antes restrita ao Procurador-Geral da República) e de direitos constitucionalmente consagrados (que exigem políticas públicas para sua efetivação) abriu brechas para uma maior presença do Poder Judiciário na arena política (SADEK, 2004). Ademais, fatores outros como a maior consciência da população seus direitos, a urbanização, a globalização, a inflação legislativa, o aumento das relações de consumo e a privatização dos serviços públicos engendraram novas fontes de litigiosidade que reclamam a intervenção do Poder Judiciário nas relações sociais. De outro lado, como sublinha José Eduardo Faria, o modelo de justiça brasileiro não dá conta da complexidade da sociedade brasileira, operando como se ela tivesse composição homogênea (com desprezo às desigualdades socioeconômicas existentes entre os brasileiros) e como se os conflitos levados até ela tivessem todos caráter interindividual (com desprezo à dimensão coletiva de certos conflitos, como os habitacionais e fundiários) e incorrendo em um excesso de formalismo que se perde em tecnicalidades e torna o processo judicial bastante moroso (FARIA, 2004). Além de "anacrônico" no seu funcionamento, Maria Tereza Sadek sugere que o Judiciário, diferentemente dos demais poderes da República, passou incólume pelo processo de democratização, permanecendo apegado a suas tradições e desincumbido de qualquer tipo de prestação de contas à sociedade, sendo encarado como uma "caixa preta" por conta da sua falta de transparência (SADEK, 2003).

Com base nesse diagnóstico, a Secretaria foi criada para encabeçar iniciativas de aprimoramento institucional do Poder Judiciário, que garantissem, de uma parte, uma prestação jurisdicional mais célere e de qualidade e, de outra, uma maior abertura para a sociedade, dado que, no entendimento do Ministério da Justiça:

\footnotetext{
${ }^{14}$ Para uma discussão mais aprofundada a respeito da judicialização da política e das relações sociais, tanto em âmbito global como em nacional, cf., respectivamente, as obras de C. Neal Tate e Torbjörn Vallinder (TATE; VALLINDER, 1995) e de Luiz Werneck Vianna et al. (VIANNA et al., 1999).
} 
O Estado Democrático de Direito pressupõe a organização de um sistema de justiça que assegure soluções rápidas, eficientes e, sobretudo, que seja acessível aos que dele mais necessitam (BASTOS, 2006, p. 15).

A rapidez, a eficiência e a acessibilidade buscadas pelo Ministério da Justiça são qualidades que a Secretaria de Reforma do Judiciário identificou nos chamados mecanismos alternativos de resolução de conflitos, entendidos como importantes para "o fortalecimento e melhoria da distribuição da Justiça", por representarem um "efetivo ganho qualitativo na solução e administração de conflitos" (RENAULT; LOPES, 2005, p. 11). Nesse sentido, a defesa da Justiça Restaurativa foi incorporada ao repertório da Secretaria da Reforma do Judiciário como uma opção, dentro do leque de formas alternativas de resolução de conflitos, específica às áreas criminal e infracional, considerando que "é no campo dos conflitos de natureza penal e infracional que nos ressentimos sobremaneira a ausência de uma intervenção diferenciada nos conflitos" (ibid., p. 11). A causa da Justiça Restaurativa foi encampada, assim, pelo Ministério da Justiça, como "uma alternativa real para o sistema de justiça criminal” (ibid., p. 11), capaz de:

assegurar acessibilidade, combater a impunidade, proteger a vítima de delitos, educar jovens em conflito com a lei e buscar a interação do Poder Público com a sociedade (BASTOS, 2006, p. 15).

O envolvimento do Ministério da Justiça com o tema da Justiça Restaurativa começou com o apoio dado a seminários, como o Seminário Internacional "Justiça Restaurativa: um caminho para os direitos Humanos?", realizado pelo Instituto de Acesso à Justiça (IAJ) e pela ONG britânica Justice UK na cidade de Porto Alegre, em outubro de 2004, e no qual foi distribuída a primeira publicação dedicada especialmente à questão no Brasil. Paralelamente, o assunto era discutido no âmbito da sociedade civil, por organizações como a Palas Athena, que, entendendo a Justiça Restaurativa como um braço da chamada "cultura de paz" no sistema de justiça, passou a divulgá-la mediante a organização de seminários como o "I Simpósio Brasileiro de Justiça Restaurativa", ocorrido da cidade de Araçatuba em abril de 2005, do qual resultou uma declaração de princípios intitulada "Carta de Araçatuba". ${ }^{15}$ Uma outra organização que já trabalhava com

\footnotetext{
${ }^{15}$ A "Carta de Araçatuba" encontra-se anexada ao final do trabalho. Em abril de 2006, foi realizado o "II Simpósio Brasileiro de Justiça Restaurativa", na cidade de Recife, na qual foi elaborada a "Carta de Recife", também anexa.
} 
o tema era o Instituto de Direito Comparado e Internacional de Brasília (IDCB), que, desde 2004, participava de uma comissão formada, por força da Portaria Conjunta $n^{\circ} 15 / 2004$ do Tribunal de Justiça do Distrito Federal, com a finalidade de estudar meios de adaptação da Justiça Restaurativa à Justiça do Distrito Federal e de promover ações para a implantação de um projeto-piloto no Núcleo Bandeirante, que mais tarde veio a se concretizar.

Aproveitando as portas abertas por essas organizações, o Ministério da Justiça e lançou, em parceria com o Programa das Nações Unidas para o Desenvolvimento (PNUD), o projeto "Promovendo Práticas Restaurativas no Sistema de Justiça Brasileiro", em 2005. O projeto foi estruturado em duas dimensões (RENAULT; LOPES, 2005). A dimensão teórica consistiu na realização de seminários e na publicação de obras coletivas, destacando-se as Conferências Internacionais "Acesso à justiça por meios alternativos de solução de conflitos", ocorrida em junho de 2005 em Brasília, na qual foram lançados o livro Justiça Restaurativa: coletânea de artigos e a chamada "Carta de Brasília"16, e "Novas direções na governança da justiça e da segurança", realizada em junho de 2006, também em Brasília, em que foi distribuída a coletânea Novas Direções na governança da justiça e da governança. A dimensão prática correspondeu à implantação de três projetospiloto no Brasil, nas cidades de São Caetano do Sul, Porto Alegre e Brasília.

O programa-piloto de São Caetano do Sul se estruturou em torno da Vara da Infância e da Juventude daquela cidade e conta com dois eixos. No primeiro, são selecionados alguns casos entre aqueles que chegam até a Vara e encaminhados à equipe técnica do juízo, que realiza encontros restaurativos no próprio espaço do fórum e submete seus resultados à apreciação do juiz e do promotor público, que fiscalizam sua legalidade e seu cumprimento e, eventualmente, aplicam medidas socioeducativas em cumulação com o acordo restaurativo. No segundo eixo, os encontros restaurativos acontecem em três escolas públicas da cidade, versando sobre conflitos entre alunos ou problemas disciplinares e contando com professores como facilitadores, e os acordos obtidos são encaminhados posteriormente à Vara da Infância e da Juventude para serem registrados, fiscalizados e, após a concessão da remissão, arquivados. O programa-piloto de Porto Alegre, por sua vez, tem lugar na $3^{\text {a }}$ Vara Regional do Juizado da Infância e da Juventude, responsável pelo acompanhamento da execução de medidas socioeducativas. Embora haja casos em que o encontro restaurativo é realizado antes da decisão final do juiz, estando os

${ }^{16}$ A "Carta de Brasília” encontra-se anexada ao final do trabalho. 
adolescentes, por exemplo, internados provisoriamente, a maioria dos casos envolve adolescentes cujos casos já foram julgados e que, portanto, já se encontram cumprindo a medida aplicada na sentença, sendo que a participação no encontro restaurativo não enseja necessariamente a sua extinção. ${ }^{17} \mathrm{O}$ projeto-piloto de Brasília, por fím, é o único que se dá fora do âmbito da Justiça da Infância e da Juventude, estando atrelado aos dois Juizados Especiais Criminais localizados na região do Núcleo Bandeirante. ${ }^{18}$

Os três projetos-piloto entraram em funcionamento no segundo semestre de 2005 e, portanto, ainda contam com um curto tempo de vida. A partir deles, novos projetos foram concebidos e outros projetos já existentes, que envolviam alguma forma de mediação na solução de conflitos, incorporaram a filosofia da Justiça Restaurativa como diretriz de atuação. ${ }^{19}$ Desde então, o número de artigos e de trabalhos acadêmicos sobre o assunto se multiplicou e os defensores da Justiça Restaurativa se organizaram no Instituto Brasileiro de Justiça Restaurativa, criado em agosto de 2007, com o fim de estimular a pesquisa, a discussão e a implementação de práticas restaurativas.

Um importante desdobramento dessas iniciativas foi a apresentação, pelo Instituto de Direito Comparado e Internacional de Brasília, em 2005, da Sugestão Legislativa ${ }^{\circ} 99$, propondo a regulamentação do uso de procedimentos restaurativos no sistema de justiça criminal brasileiro, à Comissão de Legislação Participativa da Câmara dos Deputados. Da justificativa constante do texto da Sugestão Legislativa, depreende-se que a Justiça Restaurativa foi defendida como uma medida apta a "diminuir a criminalidade por meio, não só da punição, mas do restabelecimento dos laços comunitários”. Depois da realização de uma audiência pública, a sugestão foi aprovada pela Comissão e transformada no Projeto de Lei $n^{\circ} 7006 / 2006$, que tramita atualmente no Congresso Nacional. O projeto, além de definir princípios e regrar procedimentos restaurativos, contempla a criação de núcleos restaurativos junto a varas e juizados especiais criminais e o encaminhamento de

\footnotetext{
${ }^{17}$ Já houve, entretanto, uma decisão do Tribunal de Justiça do Estado do Rio Grande do Sul que determinou a extinção da medida socioeducativa em razão da participação do adolescente em um encontro restaurativo (Agravo de Instrumento n ${ }^{\circ} 70017252008 / 2006,8^{a}$ Câmara Cível, Relator Desembargador Rui Portanova).

${ }_{18}$ Para mais detalhes - e observações críticas - a respeito do funcionamento dos projetos-piloto de São Caetano do Sul e de Porto Alegre, cf. o artigo de Mariana Raupp e Juliana Benedetti (RAUPP; BENEDETTI, 2007). O programa-piloto de Brasília consiste no nosso estudo de caso e sua análise será aprofundada adiante.

${ }^{19}$ Um exemplo de novo projeto é aquele que está sendo implementado no bairro de Heliópolis, na cidade de São Paulo, inspirado no modelo de São Caetano do Sul. Um exemplo de projeto que assimilou ideias restaurativas é o Projeto de Mediação da Vara da Infância e da Juventude de Guarulhos e das Faculdades Integradas de Guarulhos, que existe desde 2003 (informações e números sobre esse projeto podem ser encontradas no sítio http://www.fig.br/mediacao).
} 
casos em que "a personalidade e os antecedentes do agente, bem como as circunstâncias e consequências do crime ou da contravenção penal recomendarem o uso de práticas restaurativas", a esses núcleos, por sugestão da polícia ou por determinação do juiz, com a anuência do Ministério Público. O projeto permite a suspensão do processo durante o procedimento restaurativo e inclui o cumprimento de acordo restaurativo entre as causas de extinção de punibilidade, estabelecendo a interrupção do prazo prescricional pela homologação judicial do acordo, até seu efetivo cumprimento. ${ }^{20}$

Embora consista em uma iniciativa interessante, o referido projeto contém algumas lacunas e incide em certas incorreções. Por exemplo, qualifica o cumprimento do acordo restaurativo como causa da extinção de punibilidade quando, talvez, o mais adequado fosse considerá-lo como hipótese de renúncia à pena, já que esse instituto, existente no ordenamento jurídico-penal alemão, evidencia com mais clareza a eventual desnecessidade político-criminal de aplicação da pena (SICA, 2007). Além disso, é incoerente incluir o cumprimento do acordo entre causas de extinção da punibilidade que são obrigatórias e afirmar, ao mesmo tempo, que o acordo restaurativo "deve necessariamente servir de base para a decisão judicial final". Esse dispositivo sugere que o acordo restaurativo não impede a imposição cumulativa de uma pena e, portanto, não pode ser uma causa obrigatória de extinção da punibilidade. A solução ideal seria considerar, de maneira clara, o cumprimento do acordo restaurativo como causa de extinção da punibilidade nos casos em que o procedimento ocorra antes da proposição da ação penal e como hipótese facultativa de renúncia à pena nos casos em que ele aconteça depois que o processo penal já tenha se iniciado. Ademais, não há qualquer menção quanto à impossibilidade de bis in idem, no caso de eventual cumulação de acordo restaurativo com pena. Seria recomendável que, em se admitindo a cumulação, ela só se dê com relação a penas restritivas de direitos e, nunca, com penas privativas de liberdade. Uma outra lacuna, enfim, consiste na ausência de qualquer dispositivo referente à aplicação da Justiça Restaurativa no âmbito da Justiça da Infância e da Juventude. A principal crítica a se fazer em relação ao projeto, contudo, radica no fato de que ele tende a vincular irreversivelmente a Justiça Restaurativa ao sistema de justiça criminal, tolhendo a possibilidade de que ela se desenvolva fora dele. Uma vez que a Justiça Restaurativa seja regulamentada dentro de estritos parâmetros

${ }^{20}$ O relatório de aprovação da Sugestão Legislativa e o respectivo Projeto de Lei encontram-se anexados ao final do trabalho. 
normativos e se transforme em um braço do Poder Judiciário, a tendência é a de que sua prática se enrijeça e atores sociais externos sejam alijados da sua condução.

\subsection{Estudo de caso: o Projeto-Piloto de Justiça Restaurativa dos Juizados Especiais Criminais do Núcleo Bandeirante-DF}

\subsubsection{Notas metodológicas}

Os três projetos-piloto de Justiça Restaurativa resultantes da parceria firmada entre a Secretaria de Reforma do Judiciário do Ministério da Justiça e o Programa das Nações Unidas para o Desenvolvimento (PNUD) foram objeto de uma pesquisa de "Sistematização e Avaliação de Experiências de Justiça Restaurativa" empreendida pelo Instituto Latino- Americano das Nações Unidas para Prevenção do Delito (Ilanud) entre 2005 e 2006. O propósito da pesquisa era descrever, de modo sistemático, o funcionamento dos projetos-piloto - dando conta de sua forma de organização e de seus fluxos procedimentais -, a fim de identificar boas práticas e eventuais pontos de estrangulamento e de oferecer, assim, subsídios para o aprimoramento dessas iniciativas. A investigação, de caráter qualitativo, conjugou diferentes técnicas, abrangendo a análise documental, a observação in loco e a realização de entrevistas semi-estruturadas. ${ }^{21}$

O presente trabalho pretende reexaminar os dados, levantados por ocasião da pesquisa realizada pelo Ilanud, relativos a um dos três projetos-piloto então avaliados. Embora a investigação do Ilanud tivesse uma ambição mais modesta, a riqueza do material colhido permite uma análise da Justiça Restaurativa que vai além de seus aspectos meramente institucionais. Serão utilizados, portanto, os dados do Ilanud como dados secundários, com o fim de examinar elementos que, por extrapolarem seus objetivos mais imediatos, não foram detalhadamente abordados na pesquisa original. As fontes correspondem a relatórios de pesquisa e a anotações e gravações de campo do Ilanud, bem como a um questionário respondido pela equipe do projeto-piloto. ${ }^{22}$

\footnotetext{
${ }^{21}$ Maiores informações sobre os resultados da pesquisa podem ser encontradas no artigo de Mariana Raupp e Juliana Benedetti (RAUPP; BENEDETTI, 2007).

${ }^{22}$ A grande vantagem do presente trabalho em relação a uma mera análise de dados secundários reside no fato de que a autora participou diretamente da coleta primária dos dados, como pesquisadora do Ilanud.
} 
A análise consistirá em um estudo de caso do projeto-piloto de Justiça Restaurativa instalado nos dois Juizados Especiais Criminais do Núcleo Bandeirante, no Distrito Federal, e visitado pelos pesquisadores do Ilanud em novembro de $2005 .{ }^{23}$ Qualquer estudo de caso, assim como qualquer pesquisa qualitativa, levanta algumas questões de ordem metodológica. Em primeiro lugar, cabe saber o que constitui um "caso". Um caso, grosso modo, consiste em uma unidade de análise. Ocorre que essa unidade pode ser composta, por assim dizer, por várias "subunidades" (RAGIN, 1992). Definimos, assim, nosso caso como sendo o projeto-piloto do Núcleo Bandeirante, mas ele será construído a partir de "subcasos", isto é, por casos específicos de conflitos submetidos ao projeto, que conformarão o cerne da nossa análise.

Um outro problema a ser enfrentado diz respeito à afirmação comum de que o estudo de caso não preenche os requisitos de "replicabilidade" e de "generalizabilidade" próprios da pesquisa científica (BABBIE, 2005), já que é impossível replicá-lo em condições idênticas às do caso original e estender validamente suas conclusões à generalidade de casos. Isso não quer dizer, no entanto, que o estudo de caso seja incapaz de aportar ganhos teóricos. Embora não se possa, de fato, estabelecer relações causais genéricas, de modo taxativo, a partir de um único ou de um pequeno número de casos (LIEBERSON, 1992), existem, como aponta Dietrich Rueschemeyer, no repertório das ciências sociais, diversos estudos de caso que contribuíram de maneira significativa para a compreensão geral de determinados fenômenos sociais e que representaram, assim, consideráveis avanços científicos - como os estudos de E. P. Thompson sobre a formação da classe trabalhadora na Inglaterra, de Robert Michels sobre o Partido Social-Democrata alemão e de Theda Skocpol sobre as revoluções francesa, russa e chinesa, por exemplo (RUESCHEMEYER, 2003).

A pesquisa qualitativa se funda em um critério de plausibilidade, ou seja, traz aportes à ciência se conseguir estabelecer conexões pertinentes entre dois ou mais fenômenos (SENNETT, 1988). Assim, a plausibilidade de um estudo de caso depende, em grande medida, da escolha do caso, isto é, da relevância das reflexões que se possam formular a partir dele. Com efeito, o que faz um "bom caso", nas ciências sociais, é a sua significância teórica (WIEWORKA, 1992).

\footnotetext{
${ }^{23} \mathrm{O}$ uso, na presente dissertação, dos dados extraídos da pesquisa do Ilanud junto ao Projeto-Piloto de Justiça Restaurativa do Núcleo Baideirante foi autorizado tanto pelo juiz coordenador do Projeto- Piloto, quanto pelo Ilanud.
} 
No presente trabalho, a eleição do caso recaiu sobre o projeto-piloto do Núcleo Bandeirante, em detrimento dos demais contemplados pela pesquisa do Ilanud, por tratarse do único que funciona no sistema de justiça criminal de adultos. A Justiça da Infância e da Juventude apresenta uma série de particularidades que poderiam comprometer a abrangência do potencial heurístico da pesquisa, uma vez que observações relativas a esse ramo especial do Poder Judiciário não são, necessariamente, extensíveis aos sistema de justiça criminal como um todo. Dentro dos "subcasos" do nosso caso, selecionamos cinco conflitos: três, que se encontravam ainda em andamento quando da pesquisa, com o propósito de explicitar a dinâmica dos procedimentos restaurativos (um relativo a uma consulta, um relativo a um encontro preparatório e outro relativo a um encontro restaurativo), e outros dois, já concluídos no momento da pesquisa, que serão analisados em maior profundidade (um em que houve e um em que não houve acordo restaurativo). Na pesquisa do Ilanud, os três primeiros foram objeto de observação direta, ao passo que os dois últimos, por já se encontrarem terminados, foram abordados por meio do exame de processos judiciais e de entrevistas com as partes envolvidas no conflito. Consideramos que o caso e os "subcasos" escolhidos são oportunos para se pensar a relação existente entre a Justiça Restaurativa e um tipo específico de sociabilidade a que chamamos “comunidade". Não se pretende que as conclusões obtidas sejam verificáveis na generalidade dos casos; esperamos apenas que, com o presente estudo de caso, possamos compreender melhor o sentido social do fenômeno da Justiça Restaurativa. Os três primeiros "subcasos" serão apresentados, brevemente, quando da exposição do funcionamento do projeto; os demais serão analisados, em maior minúcia, depois de algumas palavras sobre o cenário, a organização e o funcionamento do projeto-piloto, bem como sobre o que as pessoas incumbidas da sua condução entendem por Justiça Restaurativa. $^{24}$

\subsubsection{Cenário}

\footnotetext{
${ }^{24}$ Como afirmado, o presente trabalho foi realizado com base nos dados coletados pelo Ilanud, em pesquisa que foi realizada entre 2005 e 2006. Retrata, assim, um momento determinado do projeto-piloto analisado, a partir do qual foi construída, indutiva e posteriormente, toda a nossa reflexão. De qualquer forma, em janeiro de 2009, foi aplicado um novo questionário, a fim de atualizar alguns dados colhidos naquele então e de oferecer um panorama mais recente do projeto-piloto. O questionário e suas respostas encontram-se anexados no final da dissertação.
} 
A competência territorial dos dois Juizados Especiais Criminais do Núcleo Bandeirante abrange cinco Regiões Administrativas do Distrito Federal: Núcleo Bandeirante, Candangolândia, Riacho Fundo I, Riacho Fundo II e Parkway. A origem do Núcleo Bandeirante e da Candangolândia se confunde com a criação de Brasília, quando se estabeleceram, no entorno da área que viria a ser o Plano-Piloto de Brasília, loteamentos, com caráter provisório, destinados a abrigar a mão-de-obra e os serviços de apoio necessários à construção da nova capital do país. Dessa forma, na região da Candangolândia, então chamada de "Velhacap", foi erguido o primeiro acampamento oficial de Brasília, no qual se instalaram funcionários e operários da Companhia Urbanizadora da Nova Capital do Brasil (Novacap). Na área do Núcleo Bandeirante, por sua vez, foram concedidos lotes para empresários e comerciantes, em sistema de comodato, e, a fim de se estimular a economia local, determinou-se que a produção e a circulação de bens, na região, estaria isenta de tributação, com o que ela ficou conhecida como "Cidade Livre". Assim, a Candagolândia e o Núcleo Bandeirante nasceram com vocações específicas - residencial e comercial, respectivamente - e com prazo de duração determinado, marcado para terminar na data de fundação da capital.

\section{Regiões Administrativas do Distrito Federal}

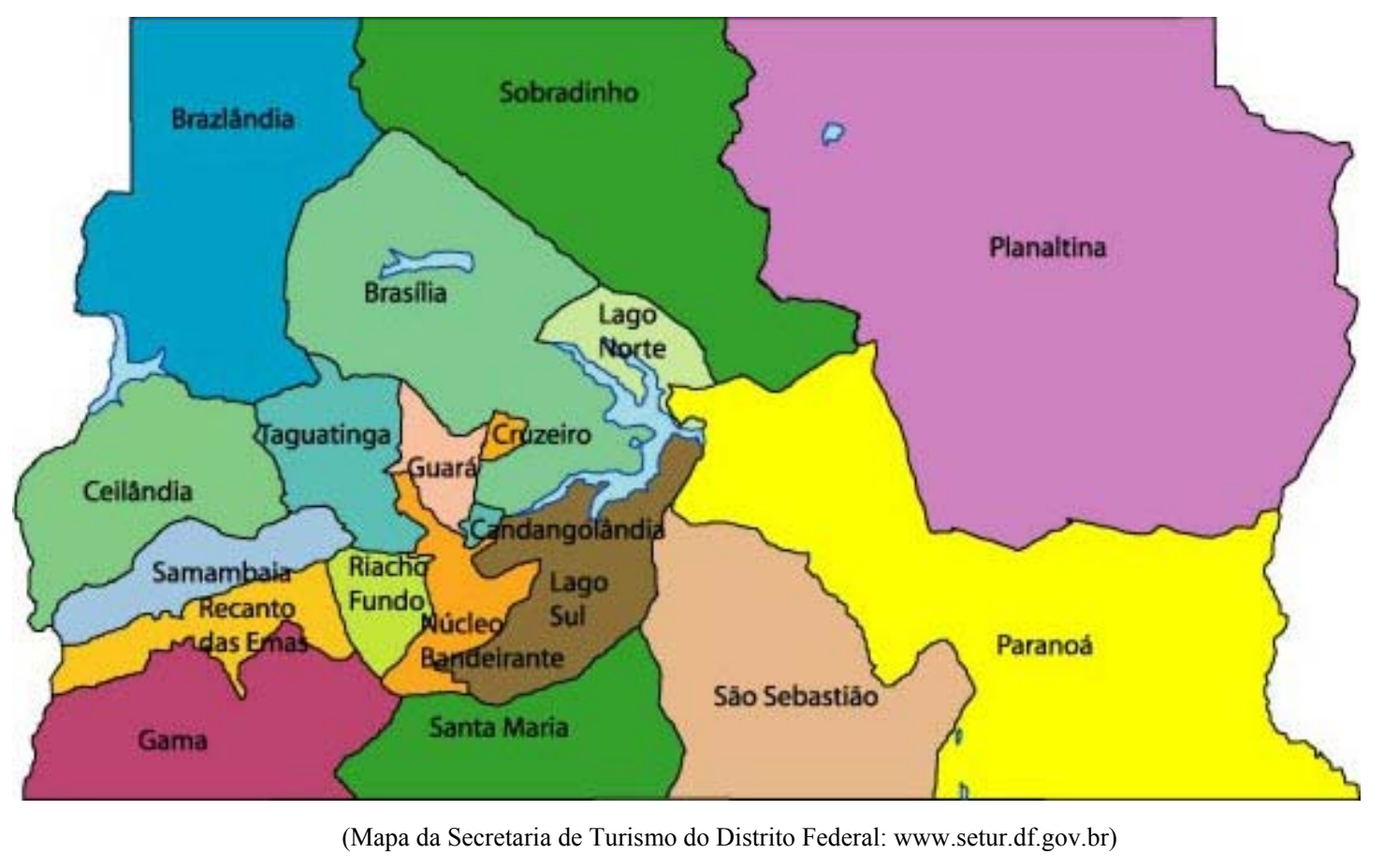


Com a inauguração de Brasília, em 21 de abril de 1960, esses primeiros polos de ocupação do Distrito Federal tornaram-se ilegais. A Novacap pretendia que o comércio estabelecido no Núcleo Bandeirante fosse deslocado para o Plano-Piloto e que parte da população da Candangolândia e de outros assentamentos fosse dividida entre a cidade de Brasília e algumas colônias agrícolas que seriam fundadas na área rural do Distrito Federal, devendo a população excedente retornar a seus Estados de origem. Essa disposição, é claro, chocou-se frontalmente com os interesses dos habitantes e comerciantes já enraizados nas áreas pioneiras, dando início a uma época de acirrado confronto entre a população, que se organizou em associações de moradores e movimentos pró-fixação, e o governo federal, que insistiu, durante algum tempo, na retirada das pessoas instaladas no entorno de Brasília. Com cessões realizadas pelas duas partes, a situação fundiária dos pioneiros regularizou-se, havendo a Novacap abandonado seus planos iniciais em favor da criação de cidades-satélites ao redor de Brasília, as quais, no entanto, nem sempre respeitavam o perfil de ocupação original. De qualquer modo, o percurso da ilegalidade à legalidade desses primeiros núcleos, caracterizado por uma sequência trifásica constituída pela ocupação irregular, pela resistência à remoção e pelo reconhecimento oficial, tornouse o padrão de ocupação do Distrito Federal.

O processo de ocupação do Distrito Federal, conforme nota James Holston, oscilou entre ciclos de rebelião e de legitimação, que corresponderam a períodos de intensa mobilização política da população e períodos de desmobilização seguidos à conquista de reivindicações populares (HOLSTON, 1993). As regiões de Riacho Fundo I e Riacho Fundo II, por exemplo, também surgidas como áreas de ocupação irregular, participaram dessa mesma dinâmica até os anos noventa, quando foram finalmente regularizadas e desmembradas da Região Administrativa do Núcleo Bandeirante. A exceção à regra é a região de Parkway, cujas características mantiveram-se praticamente inalteradas desde que foi concebida, à época da construção de Brasília, como um setor de mansões. Antes um bairro do Núcleo Bandeirante, ela tornou-se uma região administrativa autônoma em 2003 e consiste, hoje, em uma área residencial de alto padrão, com a presença de alguns condomínios fechados.

Não obstante o abandono da região por uma parcela da população ameaçada de remoção, a desmobilização ocasionada pela conquista de direitos de ocupação e a descaracterização de certas áreas por conta da reordenação do território promovida pela 
ação governamental, o histórico de lutas pela fixação à terra teve como saldo, de modo geral, o estabelecimento de um forte vínculo entre os habitantes e o lugar, interpretado como um "saudável bairrismo". ${ }^{25}$ Porém, ainda há, tendo em vista que o início da ocupação ocorreu há apenas meio século, um grande número de pessoas que não são naturais da região.

A população atual das cinco regiões administrativas soma entre 150 e 200 mil habitantes, distribuída em aproximadamente $150 \mathrm{~km}^{2}{ }^{26}$

\subsubsection{Organização}

A origem do Projeto-Piloto de Justiça Restaurativa dos Juizados Especiais Criminais do Núcleo Bandeirante remonta à já mencionada Portaria Conjunta $\mathrm{n}^{\circ} 15$, publicada, em 21 de junho de 2004, pelo Presidente, pelo Vice-Presidente e pelo Corregedor do Tribunal de Justiça do Distrito Federal e Territórios, com o fim de instituir uma comissão mista para estudar a conveniência da implementação de um projeto-piloto de Justiça Restaurativa no Núcleo Bandeirante. Faziam parte da comissão uma desembargadora o Tribunal de Justiça, um juiz do Núcleo Bandeirante e representantes do Ministério Público, da Ordem dos Advogados do Brasil (OAB), da Universidade de Brasília (UnB), do Instituto de Direito Comparado e Internacional de Brasília (IDCB) e da comunidade do Núcleo Bandeirante. Os trabalhos da comissão contribuíram para a idealização do projeto e para dotá-lo de suporte institucional, mas ele apenas se tornou economicamente viável cerca de um ano depois, quando, com o financiamento do Ministério da Justiça e do PNUD, pôde enfim estruturar-se.

O projeto-piloto do Núcleo Bandeirante ocupa o espaço de três salas do prédio onde funcionam os Juizados Especiais Criminais. ${ }^{27}$ Em duas delas são realizados os encontros

\footnotetext{
${ }^{25}$ Essa expressão é utilizada para descrever o Núcleo Bandeirante no próprio sítio da sua Administração Regional (http://www.bandeirante.df.gov.br).

${ }^{26}$ Não é possível precisar a população exata porque os dados disponibilizados por cada região administrativa, além de não estarem atualizados, são de anos distintos e há dados faltantes no que diz respeito à população rural de algumas regiões. Com relação à área, também há dados equívocos.

${ }^{27}$ É importante ressaltar que a presente dissertação tem como foco a Justiça Restaurativa e não os Juizados Especiais Criminais, criados pela lei n 9099/1995, embora certamente algumas observações feitas com relação à Justiça Restaurativa também pudessem aplicar-se aos Juizados Especiais Criminais. Trata-se, com efeito, de iniciativas que têm em comum o aperfeiçoamento da administração da justiça. Atualmente, já se encontram na literatura penalista críticas de diverso teor ao funcionamento dos Juizados Especiais Criminais. Cf., por exemplo, os trabalhos de Miguel Reale Jr. (REALE JR., 2008), Salo de Carvalho e Alexandre
} 
preparatórios e restaurativos e a outra é reservada para a coordenação do projeto-piloto, abrigando os membros da equipe responsáveis por sua condução e os arquivos relativos ao projeto. A equipe do projeto é integrada por um total de trinta e três pessoas, divididas em um grupo técnico e um grupo gestor. O grupo técnico é composto uma pessoa responsável pela supervisão, uma pessoa responsável pela coordenação de capacitação de facilitadores e uma pessoa responsável pela coordenação de execução do projeto, além de vinte e dois facilitadores, uma pessoa a cargo do apoio administrativo e um estagiário. A supervisora e a coordenadora de capacitação são formadas em psicologia, a coordenadora de execução é formada em serviço social e os facilitadores têm formação variada - a maior parte consiste em bacharéis ou estudantes de direito ou psicologia, mas também há facilitadores das áreas de pedagogia, serviço social e, até mesmo, geografia e teologia. Os facilitadores, capacitados em um curso de mediação e princípios restaurativos ministrado pelo professor da UnB André Gomma de Azevedo e supervisionados mensalmente, são todos voluntários, sendo selecionados por sua disponibilidade de tempo, experiência em solução de conflitos ou envolvimento com atividades comunitárias. As únicas pessoas que se dedicam exclusivamente ao projeto são as duas coordenadoras, o apoio administrativo e o estagiário. O grupo gestor, por sua vez, é composto por dois juízes, três promotores públicos e um defensor público - todos atuantes nos Juizados Especiais Criminais do Núcleo Bandeirante -, além da supervisora, das duas coordenadoras e de um facilitador. O grupo gestor se reúne quinzenalmente para avaliar o andamento do projeto e estabelecer diretrizes de ação, determinando, por exemplo, o número de casos que serão encaminhados ao projeto a cada mês.

\section{ORGANOGRAMA}

\begin{tabular}{cc|c}
\hline \multicolumn{3}{c}{ Equipe do Projeto-Piloto } \\
\hline Grupo Gestor & Grupo Técnico \\
\hline \multicolumn{3}{c}{ Supervisão } \\
\hline \multicolumn{3}{c}{ Coordenação de capacitação } \\
\hline \multicolumn{3}{c}{ Coordinacão de execução } \\
\hline \multicolumn{2}{c}{ Facilitador } \\
Juízes de Direito & Outros facilitadores \\
Promotores de Justiça & Apoio Administrativo \\
Defensor Público & Estagiário \\
\hline
\end{tabular}

Wunderlich (CARVALHO; WUNDERLICH, 2002; 2005), Maria Lúcia Karam (KARAM, 2004) e Rodrigo Ghiringhelli de Azevedo (AZEVEDO, 2000). 
No momento da pesquisa, trinta e sete casos já haviam sido enviados ao projetopiloto: dezesseis deles já se encontravam concluídos (quatro com acordo e doze sem acordo), nove estavam em andamento e doze aguardavam sua distribuição a facilitadores. Desses doze casos concluídos sem acordo e, portanto, devolvidos à Justiça tradicional, oito foram frustrados pela resistência de alguma das partes em relação a práticas de Justiça Restaurativa, associada ou à indisposição de ficar cara-a-cara com a parte contrária ou à crença de que se trata de uma "punição leve".

Os casos encaminhados à Justiça Restaurativa são selecionados entre aqueles entrados nos Juizados Especiais Criminais do Núcleo Bandeirante. Tendo em vista que a competência material dos Juizados restringe-se a delitos cuja pena máxima, cominada por lei, não seja superior a dois anos, o projeto lida apenas com contravenções penais e crimes de menor potencial ofensivo, sendo os mais recorrentes a perturbação da tranquilidade (art. 65 da Lei de Contravenções Penais), as lesões corporais (art. 129 do Código Penal), a ameaça (art. 147 do Código Penal) e crimes de trânsito (especialmente, o art. 303 da lei $n^{\circ}$ 9.503/1997). ${ }^{28} \mathrm{O}$ crime de uso de substâncias entorpecentes ${ }^{29}$, embora sujeito à competência dos Juizados Especiais Criminais, não é contemplado pelo projeto-piloto. Os casos de violência doméstica, que, no período em que foi realizada a pesquisa, eram ainda tratados como lesões corporais, consistindo em crimes de competência dos Juizados Especiais Criminais ${ }^{30}$, eram encaminhados ao Núcleo Psicossocial do Núcleo Bandeirante (NUPS) e não à Justiça Restaurativa.

Entre os resultados possíveis do procedimento restaurativo estão o pedido de desculpas, a restauração emocional "através da verbalização dos sentimentos e emoções, gerando condições para construir o acordo restaurativo" e a reparação financeira (Questionário respondido pela equipe).

\footnotetext{
${ }^{28}$ Informações retiradas do questionário respondido pela equipe do projeto-piloto, constante do relatório parcial de pesquisa do Ilanud.

${ }_{29}$ À época da pesquisa, o crime de uso de substâncias entorpecentes era regulado pelo art. 16 da lei $\mathrm{n}^{\circ}$ 6368/1976, a qual foi substituída pela lei $\mathrm{n}^{\circ} 11.343 / 2006$. A nova lei disciplina o crime em seu art. 28 , tendo excluído a possibilidade de imposição de pena privativa de liberdade. A competência para seu processamento e julgamento, no entanto, segue sendo dos Juizados Especiais Criminais, por força do art. 48, $\S 1^{\circ}$ da nova lei. ${ }^{30}$ A lei $\mathrm{n}^{\circ} 11.340 / 2006$ tipificou o crime de violência doméstica, incluindo os $\S \S 9^{\circ}, 10$ e 11 ao art. 129 do Código Penal. A referida lei, conhecida como Lei Maria da Penha, cominou pena máxima de até três anos, na hipótese de serem simples as lesões corporais, e determinou aumento de pena caso se trate de lesões graves, gravíssimas ou resultantes em morte. Estabeleceu, ademais, a criação dos Juizados de Violência Doméstica e Familiar contra a Mulher para o processamento, o julgamento e a execução de causas relacionadas à prática de violência doméstica.
} 


\subsubsection{Funcionamento}

Conquanto não houvesse ainda, além da taxativa exclusão dos casos de uso de substâncias entorpecentes e de violência doméstica, critérios precisos que estipulassem a remessa de um determinado caso à Justiça Restaurativa, a seleção parecia ser realizada à luz dos objetivos que a equipe conferiu ao projeto-piloto. De acordo com a equipe, embora o objetivo imediato do projeto-piloto consista meramente em uma "testagem" do modelo restaurativo como alternativa à resposta penal, seu objetivo mediato é a "pacificação social a partir da resolução das causas subjacentes dos conflitos" (Questionário respondido pela equipe). São candidatos, assim, à Justiça Restaurativa, casos em que a equipe é capaz de identificar "conflitos subjacentes a conflitos penais" passíveis de solução pela via restaurativa. Essa noção de "conflito subjacente", também referida pela equipe como "o conflito real além do conflito aparente" é, no mais das vezes, associada a conflitos de caráter pessoal, em que os "envolvidos mantêm vínculo ou relacionamento que se projeta para o futuro e em que o conflito permanece". Daí que, na maioria dos casos, os participantes possuam "algum grau de parentesco ou de relacionamento [próximo], residindo na mesma comunidade". Nos casos em que não existe nenhum vínculo, entre os participantes, anterior à prática do delito, selecionam-se, segundo a equipe, aqueles em que se verifique "necessidade de reparação emocional ou patrimonial". 31

O encaminhamento ao projeto-piloto era, originalmente, decidido na audiência preliminar realizada posteriormente ao envio do termo circunstanciado, pela autoridade policial, ao Juizado Especial Criminal. A conveniência de remessa à Justiça Restaurativa era avaliada durante a audiência, pelo juiz, pelo promotor de justiça e, estando presente, pelo defensor público, na presença do ofensor e da vítima. Mais tarde, no entanto, definiuse que a seleção de casos seria, de preferência, realizada coletivamente, por todo o grupo gestor, nas suas reuniões quinzenais. Essa mudança, de acordo com a equipe, favoreceria o controle do número de casos enviados, permitindo um melhor planejamento da sua atuação, e a consolidação de critérios comuns de seleção.

Uma vez selecionado, o caso é levado à coordenação de execução do projeto, que o distribui a um grupo de dois ou três facilitadores que serão responsáveis pela condução de

${ }^{31}$ Trechos retirados do questionário respondido pela equipe do projeto-piloto, constante do relatório parcial de pesquisa do Ilanud. 
todo o procedimento restaurativo. Inicia-se, então, o procedimento, que se desdobra em três etapas: a consulta, o encontro preparatório e o encontro restaurativo.

O ofensor é convidado, por contato telefônico, a participar do projeto e, se demonstrar interesse, é marcado um primeiro encontro, entre ele e os facilitadores, chamado de consulta. Considerando que a participação em qualquer procedimento de índole restaurativa deve ser voluntária, a consulta é o momento em que, uma vez apresentada a Justiça Restaurativa, os facilitadores obtêm o consentimento do autor. Concordando o autor, é realizada uma consulta, nos mesmos moldes, com a vítima.

A consulta observada pelos pesquisadores do Ilanud envolveu três facilitadores e um homem jovem, que havia sido vítima de lesões corporais provocadas em um acidente de trânsito. A equipe mantêm, para fins estatísticos, um registro do perfil das pessoas participantes do projeto-piloto e, por essa razão, a primeira atitude das facilitadoras, nessa consulta, foi coletar alguns dados pessoais a respeito da vítima. Enquanto uma delas anotava, a outra solicitava à vítima informações sobre sua data de nascimento, endereço, naturalidade, grau de instrução, profissão, situação ocupacional, renda, estado civil e número de filhos, religião, situação habitacional e atividades comunitárias. Segundo as informações oferecidas pela equipe do projeto, os envolvidos em conflitos remetidos à Justiça Restaurativa são majoritariamente homens, de até trinta e cinco anos, moradores da Candangolândia, Riacho Fundo I ou Riacho Fundo II, praticantes de religiões protestantes, empregados no setor formal da economia (embora haja um significativo número de trabalhadores autônomos e desempregados), com renda mensal entre $\mathrm{R} \$ 500,00$ e $\mathrm{R} \$ 1.000,00$ e nível de escolaridade baixo (ensino fundamental incompleto) ou elevado (ensino superior incompleto). ${ }^{32}$

A seguir, as facilitadoras passaram a perguntas mais abertas, sobre a opinião da vítima a respeito do sistema de justiça criminal. Uma as facilitadoras perguntou à vítima como ela via a justiça, ao que ela respondeu que considerava a justiça muito falha e reclamou que o juiz, na audiência preliminar, favoreceu o ofensor, em virtude do fato de ele estar acompanhado. A vítima, por não ter levado ninguém consigo, sentiu que o equilíbrio de forças pendeu a favor do autor do delito no momento da audiência e que o juiz não the deu suficiente atenção. A facilitadora passou logo a outra questão,

\footnotetext{
${ }^{32}$ Dados retirados do questionário respondido pela equipe do projeto-piloto, constante do relatório parcial de pesquisa do Ilanud.
} 
perguntando à vítima qual era a sua expectativa em relação à Justiça Restaurativa. Até esse momento, a vítima não tinha praticamente nenhum conhecimento sobre a Justiça Restaurativa, a não ser os breves comentários realizados pelas facilitadoras ao telefone e no início da consulta. A vítima, então, levantou os ombros, como se não soubesse muito bem como responder, e disse, vagamente, que sua expectativa é a melhor possível. As facilitadoras explicaram, então, com mais detalhe, em que consiste a Justiça Restaurativa. Afirmaram que se trata de um meio alternativo de resolver conflitos, em que algumas pessoas atuam como facilitadores, ajudando as partes a chegarem a uma solução por meio do diálogo. Uma das facilitadoras sublinhou que os facilitadores não têm "poder de juiz", isto é, que eles não imporão nenhuma decisão às partes. Nesse momento, a vítima interrompeu a fala e demonstrou sua insatisfação com a postura do juiz na audiência preliminar, dizendo que "só ele falou". As facilitadoras disseram que ambas as partes serão escutadas e que poderão trazer pessoas de apoio. Alertaram que o tom de fala devia ser respeitoso, para que ninguém se ofendesse, mas que podia ser "emocional". Disseram também que, a não ser que um novo crime fosse relatado, seria garantida a confidencialidade de tudo o que fosse discutido, sendo comunicado ao juiz apenas o resultado do procedimento.

As facilitadoras, então, explicaram longamente como seria o procedimento a partir da consulta, discorrendo sobre a realização dos encontros preparatórios e, ao final, do encontro restaurativo. A vítima pareceu se aborrecer com a explicação demasiadamente extensa e perguntou quanto tempo demoraria o procedimento até a sua conclusão, ao que as facilitadoras responderam que tudo dependeria do andamento do caso. As facilitadoras, então, indagaram se a vítima gostaria de se manifestar. Além de reclamar sobre o tratamento pouco atencioso que recebeu na delegacia de polícia, a vítima se queixou da indiferença do ofensor. Disse que conhecia o irmão do ofensor e que procurou a família dele para tentar negociar algum tipo de ressarcimento pelos gastos médicos em que incorreu por conta do acidente, mas que a mãe do rapaz mandou-o "procurar a justiça", por achar que ele iria "se safar com a doação de cestas básicas". Afirmou que acreditava que o ofensor estava fugindo de sua responsabilidade. Contabilizou minuciosamente todos as despesas médicas com as quais teve que arcar e enfatizou, ao longo de toda a sua fala, que buscava uma reparação econômica. 
No fim da consulta, as facilitadoras agendaram um encontro preparatório com a vítima. Quando a vítima se retirou da sala, passaram a discutir o caso entre elas. Uma delas disse que o caso era muito difícil porque as partes não se conheciam e não tinham envolvimento pessoal anterior. Uma outra desconfiou que a quantia pleiteada pela vítima a título de reparação fosse elevada demais. Todas concordaram que era preciso "trabalhar mais o lado emocional da questão", já que, embora ressentida, a vítima tinha se limitado, sobretudo, aos aspectos financeiros do conflito.

Os encontros preparatórios, que se seguem à consulta, também são realizados separadamente com cada uma das partes e suas pessoas de apoio. O objetivo desses encontros é levantar pontos a serem discutidos no encontro restaurativo, bem como fomentar, no ânimo das partes, uma maior disposição para o diálogo. Não há um número definido de encontros preparatórios - podem ser realizados tantos quanto os facilitadores julgarem necessários, até que autor e vítima estejam preparados para o encontro restaurativo. $\mathrm{O}$ encontro preparatório observado pelos pesquisadores do Ilanud reuniu três facilitadoras, uma vítima de acidente de trânsito e seu marido. Antes de que a vítima e seu marido entrassem na sala, as facilitadoras comentaram que o caso era difícil porque a vítima estava muito ressentida com o acidente e, por isso, não muito aberta ao diálogo. Já não era o primeiro encontro preparatório realizado com a vítima, mas, como era a primeira vez em que o marido dela comparecia, uma das facilitadoras explicou-lhe rapidamente como funcionava a Justiça Restaurativa, descrevendo seu procedimento, e deu-lhe oportunidade de fala. $\mathrm{O}$ marido disse que ele e a vítima se sentiram prejudicados pelo fato de a empresa em que trabalhava o ofensor - que era proprietária do carro que ele dirigia quando houve o acidente - tê-lo protegido. A facilitadora informou que, no encontro preparatório realizado com o ofensor, ele informou que a empresa se dispôs a indenizar as vítimas pelos danos. A vítima e seu marido ficaram satisfeitos, mas pareceram desconfiar de que a proposta fosse realmente vingar.

O marido da vítima reclamou, ademais, que "o juiz estava do lado dele”, referindose ao ofensor. Ele mostrou-se preocupado com o fato de as discussões realizadas no decorrer do procedimento restaurativo não serem levadas ao conhecimento do juiz, temendo que, nada sabendo sobre o teor das conversas, decidisse em favor do ofensor. $\mathrm{O}$ marido demonstrou também preocupação a respeito da reparação material - sabendo que a empresa estava disposta a pagar pelos danos, queria discutir valores e modos de 
pagamento. As facilitadoras, no entanto, evitaram debater tanto a questão da confidencialidade dos procedimentos restaurativos quanto as minúcias do ressarcimento e buscaram direcionar a discussão para os sentimentos da vítima e de seu marido. A vítima manifestou seu desejo de avançar para a etapa do encontro restaurativo. As facilitadoras resistiram, preferindo agendar mais um encontro preparatório, mas, ao final, cederam e decidiram marcar o encontro restaurativo.

O encontro restaurativo é o ápice do procedimento. É o momento em que, finalmente, vítima e ofensor, acompanhados de suas respectivas pessoas de apoio e auxiliados pelos facilitadores, encontram-se para discutir o melhor modo de solucionar o conflito existente entre eles. $\mathrm{O}$ encontro restaurativo observado pelos pesquisadores do Ilanud foi protagonizado por seis rapazes: três figuravam como autores e três figuravam como vítimas, sendo que duas das vítimas eram menores de idade. Os jovens haviam-se envolvido em uma briga, durante uma festa, e os rapazes mais velhos foram acusados de lesões corporais (art. 129, CP) e ameaça (art. 147, CP). Os adolescentes também haviam sido acusados, pelos jovens mais velhos, do crime de ameaça, mas, sendo o Juizado Especial Criminal incompetente para processar atos infracionais, sua responsabilidade não foi objeto de discussão e não houve sequer encaminhamento do caso à Justiça da Infância e da Juventude. Além dos jovens, estavam presentes dois facilitadores e quatro pessoas de apoio (uma quinta pessoa chegou no fim do encontro), que eram parentes dos rapazes. Os jovens e os facilitadores sentaram-se em cadeiras colocadas em um círculo e as pessoas de apoio sentaram-se atrás dos demais. Todos usavam etiquetas com seus respectivos nomes.

Uma facilitadora explicou que cabia às partes, naquela ocasião, pensar conjuntamente em uma solução para o conflito. Disse que o acordo seria uma consequência natural da discussão e que, uma vez redigido, seria remetido ao juiz apenas para ser homologado. Explicou também que, se não houvesse acordo, o caso voltaria à Justiça tradicional e seria submetido a julgamento. Pediu que todos respeitassem a fala uns dos outros, que escutassem atentamente e aguardassem sua vez de falar. Em seguida, pediu que cada um compartilhasse seus sentimentos com os demais. Todos ficaram em silêncio até que um dos ofensores tomou a iniciativa e pediu desculpas - disse que já havia se desculpado pessoalmente com os ofensores "na rua" e que reiterava o pedido naquele momento. O segundo ofensor, que falou o tempo todo olhando para baixo, disse também estar muito arrependido e envergonhado. O terceiro disse que queria pedir desculpas 
também para os pais ali presentes. Um facilitador pediu que as vítimas, então, se manifestassem sobre o pedido de desculpas e sobre o que gostariam que os ofensores fizessem para reparar os danos sofridos. As vítimas, também olhando par baixo, falaram pouco, mas aceitaram as desculpas. Uma das vítimas sugeriu que os ofensores escrevessem uma carta de desculpas e disse que os problemas deveriam ser resolvidos "lá fora" e não na Justiça.

Logo depois, um dos facilitadores lembrou que, durante os encontros preparatórios, as vítimas queixaram-se de que alguns de seus pertences tinham sido furtados durante a briga - um celular, uma corrente de prata e um óculos de sol. A partir desse momento, todo o debate passou a versar a respeito desses bens. Um dos ofensores disse que nenhum deles furtou nada e que outras pessoas devem ter-se aproveitado da briga para fazê-lo. A tia de um dos ofensores pediu desculpas, disse que os rapazes não deviam ter consumido álcool na festa e prontificou-se a pagar pelos objetos perdidos. A irmã de um dos ofensores também os recriminou pelo abuso de bebidas alcoólicas, mas disse que, apesar de tudo, o fato foi positivo por ter tido a oportunidade de conhecer melhor as vítimas. Um dos ofensores se dispôs a fazer uma doação a alguma entidade beneficente ou a fazer algum trabalho voluntário. O pai de um dos rapazes disse que era importante que eles mudassem "de mentalidade", elogiou o projeto-piloto e apoiou a ideia de que eles fizessem algum tipo de trabalho voluntário. Uma das vítimas sugeriu uma instituição e os demais ofensores concordaram. Uma outra vítima, no entanto, protestou e disse que o trabalho voluntário não traria nenhum benefício a ele, que alegou ter tido um prejuízo de cerca de dois mil reais com o furto dos objetos. Um dos ofensores respondeu que poderia pagar pelos danos, desde que ele se comprovasse que as vítimas realmente tiveram seus bens furtados - já que achava estranho que a vítima estivesse com um óculos de sol à noite, no horário da festa. A vítima disse que tinha ido para a festa direto de outro lugar, onde fazia sol, e insistiu que os ofensores comprassem-lhe um novo óculos. Uma outra vítima, então, propôs que os ofensores comprassem objetos usados, em substituição àqueles perdidos, a fim de não gastarem tanto, com o que todos concordaram.

Os familiares dos envolvidos, no entanto, insistiram na ideia do trabalho voluntário, para que os rapazes "mudassem de pensamento". Uma das pessoas sugeriu que os rapazes ajudassem na arrecadação de brinquedos para o Natal realizada pela Igreja e eles consentiram. O facilitador, então, passou à redação do acordo, contemplando tanto o 
serviço comunitário quanto a reparação material pela perda dos bens das vítimas. $\mathrm{O}$ facilitador foi extremamente minucioso em termos de técnica jurídica e sugeriu a previsão de uma multa, a ser cobrada no caso de não cumprimento do acordo. Ele explicou que, nesse caso, o acordo, na condição de título judicial, podia ser executado na Justiça pelas vítimas. Todos assinaram o acordo e o encontro terminou. A mãe de uma das vítimas, ao levantar-se para ir embora, comentou que, na época em que era jovem, brigas de adolescentes não precisavam ser resolvidas na Justiça e que considerava todo o procedimento desnecessário.

Uma vez finalizado o acordo, ele é remetido, junto com um relatório, escrito pelos facilitadores, descrevendo brevemente o andamento do caso até o encontro restaurativo, para o Juizado Especial Criminal, onde o promotor público e o juiz examinam seu teor e homologam-no. Juiz e promotor não podem alterar o acordo restaurativo; cabe a eles, apenas, verificar se o acordo foi celebrado em observância à lei e com respeito às garantias legais das partes. Se não houve acordo, o caso volta aos trâmites normais do Juizado Especial Criminal.

FLUXOGRAMA

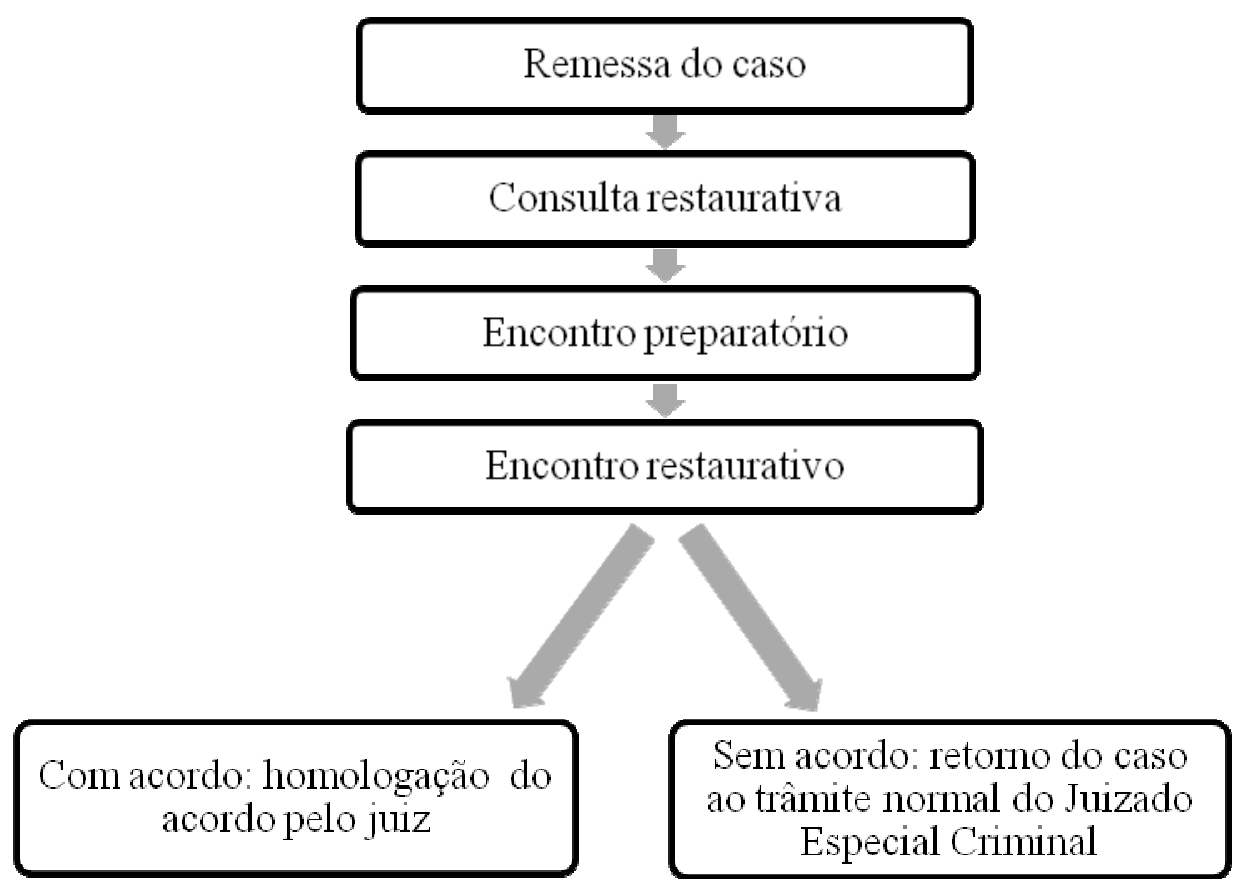




\title{
2.3.5. Concepção de Justiça Restaurativa
}

Os membros do grupo gestor do programa-piloto do Núcleo Bandeirante não definem a Justiça Restaurativa de maneira unívoca, reportando-se a ela, sobretudo, por meio de alusões a algumas de suas características que reputam fundamentais ou que a diferenciam do sistema de justiça criminal tradicional. Assim, a Justiça Restaurativa é vista como um modelo alternativo de justiça, que se opõe a um "padrão tradicional de justiça rígido e extremamente pautado em normas legais (Membro do Grupo Gestor 3) e que se baseia no "respeito à vontade das partes" (Membro do Grupo Gestor 4) e na "possibilidade de as pessoas discutirem o evento ocorrido" (Membro do Grupo gestor 6), com vistas à obtenção de uma "reparação simbólica" (Membro do Grupo Gestor 3). Num esforço de síntese, perceptivelmente inspirado nas definições consagradas pela literatura e pelos documentos que abordam o tema da Justiça Restaurativa, um dos integrantes da equipe assim a conceituou:

\begin{abstract}
A Justiça Restaurativa é um procedimento no qual as pessoas envolvidas em um conflito se reúnem para debater coletivamente e para estipular a maneira como vão lidar com esse conflito, além de traçar metas para o futuro e parâmetros de convivência pautados em eixos como o respeito ao próximo, a solidariedade (Membro do Grupo Gestor 7).
\end{abstract}

Não obstante cada um deles ressalte diferentes aspectos da Justiça Restaurativa, os integrantes da equipe responsável pelo projeto partilham de uma visão bastante homogênea a respeito do lugar da Justiça Restaurativa no sistema de justiça criminal. Todos são unânimes ao atribuir à Justiça Restaurativa um caráter meramente complementar, que dê conta de certos aspectos das situações de conflito que escapam ao alcance da justiça tradicional ou que contemple a reparação de danos "maiores do que aqueles percebidos pelo sistema formal de justiça" (Questionário respondido pela equipe). A necessidade da punição, como resposta padrão ao crime, não é colocada em questão; é apenas relativizada em circunstâncias nas quais se considera que uma ação restaurativa pode ter um impacto mais positivo seja em termos de satisfação das partes ou de pacificação social, seja em termos de credibilidade do sistema de justiça.

A Justiça Restaurativa não é uma alternativa ao sistema tradicional, mas um complemento. Não há como descolar a prática do crime e da violência 
de um sistema jurídico formal, coativo, em que a pessoa é coagida a participar do processo penal queira ela ou não. Não há alternativa para o conflito que não seja através de uma punição. Mas, evidentemente, para alguns casos se pode inserir uma alternativa de resposta, que não implica uma alternativa ao sistema de justiça (Membro do Grupo Gestor 1).

Para a o grupo gestor do projeto do Núcleo Bandeirante, assim, a Justiça Restaurativa é um "novo paradigma de justiça que não deve se sobrepor ao modelo existente" (Membro do Grupo Gestor 4) e que, portanto, não pretende substituí-lo. Ela consiste, tão-somente, em um desvio em relação ao procedimento normal, cujo rumo, se mal sucedido, deve ser reconduzido aos trilhos do sistema de justiça tradicional.

A relação entre a Justiça Restaurativa e a justiça tradicional é de complementaridade, porque se a intervenção restaurativa não for satisfatória, o caso tem que ser encaminhado para o sistema tradicional (Membro do Grupo Gestor 3).

A noção de complementaridade é, no discurso de alguns dos membros da equipe, permeada por referências ao atributo "saneador" da Justiça Restaurativa. A alusão ao caráter "saneador" da Justiça Restaurativa remonta à fala, registrada pelo Ilanud, em sua pesquisa, de um operador do projeto-piloto de Porto Alegre, para quem a Justiça Restaurativa:

não é nem uma alternativa, nem um substituto, nem uma via paralela da justiça tradicional. Ela é um germe, um anticorpo do próprio sistema, inoculando a cura de uma disfunção, que talvez seja congênita do modelo, mas não seria tão evidente se não fosse a crise burocrática do Judiciário. Esse sistema promove uma dinâmica conflitual e amplifica o conflito. A Justiça Restaurativa vem justamente impedir a reprodução do conflito. O sistema é disfuncional, além de potencializador do conflito, é fragmentário - ele exponencia a beligerância extravasada pelas pessoas. A Justiça Restaurativa é uma busca da parte saudável do sistema, pela via da conciliação. A relação entre justiça tradicional e Justiça Restaurativa é de regeneração (RAUPP; BENEDETTI, 2007, p. 16).

Essa ideia segundo a qual a Justiça Restaurativa funciona como um remédio para alguns dos males da justiça tradicional, aparece sutilmente no Projeto-Piloto do Núcleo Bandeirante. Sob essa concepção, a Justiça Restaurativa se presta a aparar algumas das arestas da justiça tradicional, com vistas, sobretudo, a resgatar o prestígio do sistema de justiça criminal junto à sociedade e a confiança que a população nele deposita. 
A Justiça Restaurativa restaura a visão da justiça. Todos estão acostumados a ver a justiça como uma imposição punitiva e a Justiça Restaurativa coloca a justiça como algo que pode ajudar as suas vidas (Membro do Grupo Gestor 5).

Conferir um caráter complementar à Justiça Restaurativa significa reconhecer que ela possui certas peculiaridades, em relação à justiça tradicional, que justificam a opção restaurativa em determinadas circunstâncias. Ao sublinhar as diferenças entre os dois modelos, os membros do grupo gestor enfatizaram a abertura oferecida pela Justiça Restaurativa à discussão das emoções que afloram da prática do delito.

A pena tem uma função de reprovar e reprimir a prática do delito e acaba sendo um mecanismo de realimentação do sistema. A Justiça Restaurativa tem uma preocupação que vai além, já que lida com o aspecto emocional das pessoas e busca reparar o dano, principalmente de caráter emocional, dando oportunidade de fala, de abrir o coração, de desabafo (Membro do Grupo Gestor 2).

Os integrantes da equipe chamaram a atenção para o fato de que esse espaço de discussão dos sentimentos concernentes ao crime não existe na justiça tradicional.

\begin{abstract}
A Justiça Restaurativa está relacionada com a possibilidade de as pessoas discutirem o evento ocorrido. Na justiça tradicional, isso não é possível e, mesmo quando é, não é suficiente para trabalhar o que está além do processo, o conflito. Não é uma solução terapêutica, mas um meio para possibilitar a fala e a expressão, sempre pautado pelos princípios restaurativos: voluntariedade e respeito para ouvir e falar, atenção à causa em conflito etc. (Membro do Grupo Gestor 6).
\end{abstract}

A ênfase nos aspectos emocionais do conflito é reputada, pelos membros do grupo, como uma das razões pelas quais a Justiça Restaurativa seria mais eficaz na prevenção de delitos. Acredita-se que o envolvimento emocional das partes, por implicar um engajamento maior na solução do conflito, pode evitar sua escalada, impedindo que redunde em conflitos mais graves. Assim, para a equipe, “a Justiça Restaurativa está voltada para o futuro" (Membro do Grupo Gestor 7), constituindo um modelo:

voltado à prevenção de conflitos. A Justiça Restaurativa visa a empoderar a coletividade na solução dos conflitos e vai mais além do que a justiça tradicional porque ela não cuida do crime, ela aborda o conflito geral e 
real. As partes são levadas a não praticarem de novo o delito, a não entrarem na justiça, a não encararem o delito como algo alheio a eles próprios (Membro do Grupo Gestor 4).

Quando as pessoas resolvem a parte emocional do conflito, é possível você prevenir outros litígios - um problema gera outro, uma discussão pode virar homicídio... (Membro do Grupo Gestor 2).

Subjaz à opinião dos integrantes da equipe a oposição à ideia vulgar de que a justiça criminal é tanto mais efetiva quanto mais severa. Sua fala sugere que, ao contrário, temperar o rigor do sistema de justiça tradicional com práticas restaurativas pode implicar um ganho de eficácia, especialmente em termos preventivos.

A Justiça Restaurativa torna a lei mais humana. Além disso, a simples punição não surte os efeitos esperados (Membro do Grupo Gestor 5).

Da atenção conferida aos aspectos emocionais do conflito também decorre a possibilidade de encaminhamento à Justiça Restaurativa de conflitos que não são, formalmente, penais. Os integrantes da equipe foram incisivos na afirmação de que a Justiça Restaurativa deve se ocupar do conflito "real" ou "subjacente" ao crime. Daí que a esfera de cognição da Justiça Restaurativa seja muito mais abrangente que a da justiça tradicional, o que a autorizaria a extrapolar, por exemplo, os limites estreitos da tipicidade penal.

\footnotetext{
Antes eu era bem rigorosa no sentido de que casos de atipicidade não deviam ser encaminhados, mas depois de um seminário vi que nem sempre existe essa necessidade, porque não estamos só tentando restaurar relações rompidas pela prática de um crime em si, mas cuidando de um conflito que pode não se adequar a um tipo penal. Se for promovido o arquivamento por uma questão mais técnica, o conflito pode permanecer, principalmente quando não existe uma definição muito clara de quem é o autor e quem é a vítima (Membro do Grupo Gestor 4).
}

Não se pode ficar preso ao modelo da justiça tradicional, já que o conflito pode ser penal ou não. É um meio de estimular as pessoas a resolverem seus próprios conflitos (Membro do Grupo Gestor 3).

Um outro diferencial da Justiça Restaurativa em relação à justiça tradicional, apontado por alguns membros da equipe, é seu maior envolvimento com a comunidade. Via de regra, entretanto, as frequentes alusões ao empoderamento da coletividade 
promovido pela Justiça Restaurativa diziam respeito às partes e às suas pessoas de apoio. Tinham vistas, sobretudo, a ressaltar a disposição dos envolvidos na resolução dos próprios conflitos.

O programa busca ampliar a participação das pessoas envolvidas no crime, a fim de que a comunidade possa participar ativamente nas questões relativas à criminalidade através da Justiça Restaurativa (Membro do Grupo Gestor 7).

Poucos integrantes do grupo gestor fizeram menção à comunidade em um sentido mais amplo e, quando o fizeram, a referência contemplava uma noção bastante abstrata de comunidade, associada a uma preocupação genérica de criar canais variados de participação e de fazer que ideais restaurativos transbordassem do sistema de justiça.

A comunidade pode atuar como participante dos encontros restaurativos e como parceiro na prestação de serviços na área social, educacional, saúde, trabalho, voltados para as partes envolvidas nos encontros, bem como para sua família. Há também uma expectativa de que a comunidade possa conhecer e apropriar-se dos princípios e práticas restaurativas para a resolução de seus conflitos cotidianos (Questionário respondido pela equipe).

Entre aqueles que se reportaram expressamente à comunidade, ela é abordada como um dos pontos sensíveis do programa. O pretendido envolvimento com a comunidade é encarado como um objetivo que não foi, ainda, satisfatoriamente alcançado.

Falta a participação da comunidade. Pretendemos organizar um fórum comunitário para divulgar os princípios da Justiça Restaurativa e chamar a comunidade para participar do projeto (Membro do Grupo Gestor 7).

Uma outra particularidade frisada pelos membros da equipe, a respeito da Justiça Restaurativa, é seu caráter multidisciplinar. As práticas restaurativas, na opinião do grupo gestor, supõem a intervenção de profissionais alheios ao campo do direito. O direito é implicitamente associado ao rigor do sistema de justiça tradicional e, sendo assim, "a humanização da justiça implica trazer outros profissionais", especialmente aqueles oriundos da área da psicologia e do serviço social (Membro do Grupo Gestor 5).

Não consigo vislumbrar hoje o tratamento do crime só com base na lei e uma leitura para além do crime traz a necessidade de outros profissionais. 
A Justiça Restaurativa possibilita a inclusão de outros atores, como assistentes sociais, psicólogas, equipe multidisciplinar (Membro do Grupo Gestor 4).

O diagnóstico que se faz do direito como um saber técnico que, por suas propriedades formais, resvala apenas na superfície dos conflitos com os quais lida, aliado à ênfase conferida à dimensão emocional do conflito, leva a que se considere o direito como uma ferramenta pouco útil à Justiça Restaurativa. A fala dos membros do grupo sugere uma distinção bem marcada entre o campo do direito e aquele que seria o âmbito da Justiça Restaurativa, cuja afinidade seria maior com relação a outras áreas do conhecimento.

Quando o trabalho é multidisciplinar, há mais pessoas capacitadas para lidar com isso, já que os operadores do direito não têm tempo para um maior envolvimento. (...) A Justiça Restaurativa abre a possibilidade de trabalhar o conflito para além do processo e o direito não é muito bem aparelhado para isso (Membro do Grupo Gestor 2).

O delito viola o interesse coletivo na medida em que viola a lei, mas, além de ferir esse interesse coletivo e essa sensação de paz coletiva, viola também as relações entre as pessoas. Esse aspecto do delito não tem um conteúdo de natureza jurídica, não pertence ao direito - pelo menos não com exclusividade -, mas a muitas outras ciências sociais. A Justiça Restaurativa é uma resposta ao delito que cuida de um outro âmbito que não o do direito, é uma resposta dada por outras ciências sociais que não as ciências jurídicas e que se refere a outro âmbito que não o jurídico (Membro do Grupo Gestor 1).

De modo coerente com o lugar reservado, conforme o pensamento da equipe, ao direito na Justiça Restaurativa, conquanto desempenhem um papel de protagonismo na condução do projeto-piloto, os profissionais do direito figuram, intencionalmente, como coadjuvantes na sua execução. Sua significativa influência na determinação das diretrizes do programa contrasta com seu escasso envolvimento nos procedimentos restaurativos propriamente ditos. Tanto juízes quanto promotores de justiça intervêm de forma bastante pontual na dinâmica restaurativa. O papel do juiz, por exemplo, é simplesmente o de "encaminhamento dos casos" (Membro do Grupo Gestor 2), até porque se entende que a autoridade do juiz deve ser preservada contra a informalidade própria da Justiça Restaurativa.

Entendo que, dentro desse conjunto de práticas que são denominadas de Justiça Restaurativa, o juiz tem um papel de condutor do processo, para 
que o processo seja encaminhado para o encontro restaurativo. Tem que haver um ato do juiz, dentro do sistema formal de justiça, que consiste em suspender o curso do processo para levar para a intervenção restaurativa e depois que ele voltar vai ganhar curso sofrendo ou não as consequências daquela intervenção. (...) O juiz não tem o domínio das ferramentas que têm os técnicos que fazem a intervenção restaurativa. Se o juiz for capacitado, pode exercer as técnicas, mas não vale a pena capacitar o juiz, porque ele tem muitas tarefas importantes para fazer no âmbito jurídico, especialmente se existem outros profissionais que já estão capacitados. Além disso, a posição do juiz é um tanto simbólica e, na medida em que se retira do juiz a sua autoridade de representante da lei, colocando o juiz para sentar numa mesa redonda junto com as partes e buscar uma conversa mais do âmbito dos sentimentos, esse papel simbólico da lei pode ser fragilizado (Membro do Grupo Gestor 1).

O papel do Ministério Publico, de modo análogo, tampouco escapa muito do figurino jurídico, visto que o promotor de justiça desempenha, na Justiça Restaurativa, a mesma função de fiscal da lei que exerce em outros procedimentos judiciais. Admite-se, contudo, que certos princípios que orientam a ação do Ministério Público no processo penal sejam relativizados.

O papel do Ministério Público na Justiça Restaurativa é sempre estar atento à proteção, às garantias e direitos fundamentais e à pacificação social. Sua função é a garantia de direitos, além de evitar a revitimização e a reincidência (Membro do Grupo Gestor 3).

A função do Ministério Público está ligada a seu papel institucional de respeito à indisponibilidade da ação penal - afinal, a vítima do crime é o Estado. Mas, na prática, existe uma vítima individualizada e uma discussão que o MP tem que enfrentar é a adoção de princípios mais modernos de pacificação social e intervenção mínima, que dá muita polêmica. Temos que lutar para mudar essa concepção mais tradicional. Se o procedimento restaurativo dá certo, não faz sentido a intervenção do Estado (Membro do Grupo Gestor 4).

\subsubsection{Casos}

A seguir, serão analisados, em detalhe, dois casos encaminhados à Justiça Restaurativa, no marco do programa-piloto do Núcleo Bandeirante. O caso ao qual nos referiremos como "caso dos concunhados" foi concluído com um acordo restaurativo, ao passo que o caso ao qual nos referiremos como "caso do atropelamento" não resultou em acordo e retornou, assim, ao trâmite normal do Juizado Especial Criminal. 


\section{Caso dos concunhados}

O caso dos concunhados reporta-se a um desentendimento familiar, ocorrido entre homens casados com duas irmãs, motivado por uma divida não paga. $\mathrm{O}$ ofensor narrou as circunstâncias que levaram ao conflito:

Antes de ocorrer o problema, meu pai faleceu, eu fiquei deprimido, pedi demissão e entrei numa situação financeira complicada. Isso me levou a recorrer ao meu concunhado e eu pedi uma importância até baixa. Dessa dívida restaram $\mathrm{R} \$ 400,00$, o resto foi honrado, e eu atrasei o pagamento desses últimos $\mathrm{R} \$ 400,00$ mais ou menos quatro dias. Nesse período, a mulher dele entrou em contato, falando coisas desagradáveis, o que me levou a procurá-lo. E foi aí que desencadeou o processo, agressões verbais, físicas, que deixou sequelas emocionais (Ofensor).

A facilitadora que cuidou do caso esclareceu que, quando os homens encontraramse para tratar da dívida, o ofensor descontrolou-se e atacou o concunhado com chutes e golpes desferidos com um pedaço de pau. A vítima dirigiu-se a uma delegacia de polícia para registrar o ocorrido e o termo circunstanciado lá lavrado tipificou os fatos em conformidade com os artigos. 129 e 147 do Código Penal - respectivamente, os crimes de ameaça e de lesões corporais. Uma vez encaminhado o termo ao Juizado Especial Criminal, foi realizada a audiência preliminar, durante a qual o juiz recomendou o encaminhamento do caso à Justiça Restaurativa.

Aceitei participar porque o juiz achou melhor que fosse resolvido na Justiça Restaurativa. Se o juiz aconselhou era porque era o melhor pra mim e eu não queria prejudicar meu concunhado, só queria o seu respeito. Se ele fosse penalizado, ele poderia ter que cumprir [a pena] e a gente teria um problema no futuro, com certeza (Vítima).

Sobre a decisão de encaminhamento do caso à Justiça Restaurativa pesou de forma determinante a existência de vínculos familiares entre as partes.

Neste caso, é um conflito que envolve a família estendida (...). A briga traz repercussão para as irmãs e para os primos, eles já eram amigos. Naturalmente, aquele relacionamento tem uma projeção para o futuro, a ruptura poderia ser causa de sofrimento para as duas famílias, então vamos ver se a gente cura essas feridas com uma resposta não jurídica e, curando essas feridas, essas pessoas poderão estabelecer um ambiente de 
convivência pacífica que não resulte em prejuízo principalmente para os filhos adolescentes que eles têm (Juiz atuante no caso).

Eles confessaram que tinham um bom relacionamento anterior e os filhos também. Era um conflito familiar, eles tinham uma relação de confiança. Houve uma ruptura do relacionamento, que poderia ser resgatado. $\mathrm{O}$ objetivo era reconstruir uma nova relação familiar através da intervenção da Justiça Restaurativa, o que, no momento da audiência, em quinze ou trinta minutos de duração, não seria possível, porque os métodos tradicionais de justiça não seriam hábeis para contornar e pacificar aquela relação conflitual. Preferiu-se apostar numa equipe disciplinar com um outro perfil que a área jurídica não pega (Promotor de Justiça atuante no caso).

Antes da realização do encontro restaurativo, foram realizadas uma consulta restaurativa e um encontro preparatório com cada uma das partes. O trabalho das facilitadoras, segundo elas próprias relataram, consistiu em um esforço de apaziguar os ânimos das partes, de modo a criar condições emocionais para uma reconciliação. No curso do procedimento, veio à tona, envolvendo não só os dois concunhados, mas também as suas mulheres, uma outra questão, que, à parte daquela que precipitou a agressão, embaraçava a reaproximação da família e que teve, portanto, de ser colocada em discussão pelas facilitadoras e superada, para que um acordo fosse possível.

Durante os encontros, nós soubemos que a irmã casada com o ofensor achava que a outra sofria agressões do marido. Era um fato que não tinha a ver com o processo, mas como a Justiça Restaurativa é mais abrangente, então houve um momento em que essa questão foi suscitada e ficou provado que não era verdade (Facilitadora).

Ao longo do procedimento restaurativo, as facilitadoras procuraram salientar o valor da convivência familiar, instando as partes a pensarem "nos momentos bons que a família teve". Desse modo, criaram nelas a disposição para um desfecho satisfatório do conflito, coroado com um pedido de desculpas do ofensor aceito pela vítima. Estando ambos mais serenos a respeito do ocorrido, o relacionamento rompido pôde ser, efetivamente, restaurado.

Aquela mágoa, aquele ressentimento acabou. No começo, eu sentia muita raiva. (...) Foi bom porque conversei com ele, na rua talvez a gente não teria essa oportunidade. Fiquei surpreso com a fala dele e o pedido de desculpas (Vítima). 
O diferencial é a reconciliação. Na justiça tradicional você tem a sentença, mas a mágoa permanece, o sentimento de revanchismo, ele permanece. A coisa pode se transformar numa tragédia. Enquanto que na Justiça Restaurativa, não. As pessoas conseguem vislumbrar coisas que até o momento não conseguiam. Antes das sessões - não sei se é assim que vocês classificam -, ele demonstrou que tinha outro pensamento. Após as sessões, ele reverteu essa intenção, essa forma de pensar dele. Ele veio transformado, eu não esperava isso (Ofensor).

As duas partes expressaram que se sentiram aliviadas com o fato de o sistema de justiça ter sido capaz de prover-lhes uma solução adequada. Sua fala deu a entender que se o Poder Judiciário não tivesse respondido a contento ou, mesmo, se tivesse se limitado a impor uma pena, ofensor e vítima seriam levados a "fazer justiça com as próprias mãos”.

Não queria fazer justiça com as minhas mãos. Eu me senti protegido pela justiça. Até hoje, não aconteceu nada (Vítima).

É melhor restaurar do que punir, porque se só punir fica aquela mágoa, o revanchismo, e acontece igual àquelas histórias do Nordeste, passa de pai pra filho, de geração. (...) Mesmo eu sendo vítima eu preferia ir para a Justiça Restaurativa. É melhor do que uma sentença ou que fazer justiça com as minhas próprias mãos e prejudicar a minha vida (Ofensor).

A Justiça Restaurativa, assim, na opinião das partes, evitou o agravamento do conflito. No entanto, tanto eles quanto uma das facilitadoras que atuou no caso mostraramse um pouco céticos a respeito do potencial da Justiça Restaurativa, quando aplicada em outros tipos de conflito.

No nosso caso, ela se adequou muito bem porque nós somos trabalhadores, nossas esposas são irmãs, nossos filhos brincam juntos. A Justiça Restaurativa encaixou como uma luva, porque não somos marginais, foi um atrito familiar, somos pessoas de boa conduta. Mas num caso diferente do nosso, por haver um histórico criminal mais extenso, ou se não são parentes, eu sugiro um número maior de sessões, talvez a presença de uma autoridade policial para garantir a segurança. Até pode ter Justiça Restaurativa, mas se fosse uma pessoa estranha, sem relação de parentesco, talvez essa reconciliação poderia ser mais demorada (Ofensor).

Acho que num primeiro momento a Justiça Restaurativa não é aplicável a todos os casos, mas eu ouso acreditar que sim (Facilitadora). 
O ofensor e a vítima avaliaram positivamente a experiência e afirmaram que se submeteriam novamente à Justiça Restaurativa, se necessário.

\section{Caso do atropelamento}

O caso do atropelamento refere-se a dois jovens, de cerca de vinte anos, envolvidos em um acidente de trânsito. No termo circunstanciado remetido do Juizado Especial Criminal, o fato foi descrito como uma lesão corporal culposa praticada na direção de veículo automotor, nos termos do art. 303 da Lei 9.503 de 1997. A vítima sofreu uma fratura na perna e o ofensor não lhe ofereceu qualquer auxílio. A esse respeito, cada parte apresentou a sua versão.

$\mathrm{O}$ acidente aconteceu em um lugar público, com várias pessoas. Para a vítima, o ofensor fugiu dali porque não queria prestar socorro. Mas o ofensor disse que teve que fugir porque as pessoas no local queriam apedrejá-lo (Facilitadora).

Tendo havido ou não a ameaça de linchamento, o envolvimento, no caso, dos moradores das quadras adjacentes ao local em que ocorreu o acidente foi bastante significativo. Dos autos do processo contava um abaixo-assinado elaborado por esses moradores que reprovava o comportamento do ofensor, dando conta de já ter sido ele flagrado por diversas vezes trafegando em alta velocidade no bairro e de ser participante frequente em "pegas" e "rachas" nas vias da região. Nenhuma das pessoas signatárias do protesto, entretanto, foi convidada a participar do procedimento restaurativo.

\footnotetext{
Quem insistiu para eu levar o caso para a Justiça foi o bombeiro que me atendeu, que disse que ele [o ofensor] sempre dirigia em alta velocidade. Não fui informado que podia trazer mais apoio, até cheguei a perguntar se poderia trazer mais gente, mas disseram que não. Eu queria ter chamado as pessoas do abaixo-assinado, que sabem que ele vivia dirigindo em alta velocidade (Vítima).
}

De qualquer modo, a repercussão social do acidente foi considerada na decisão de envio do caso à Justiça Restaurativa. A Justiça Restaurativa foi proposta, nesse caso, como uma oportunidade de conscientizar o ofensor acerca da sua responsabilidade e de fazê-lo perceber, assim, as consequências sociais das suas ações. 
Nesses casos, sempre fica um sentimento de injustiça da parte da vítima, pois ela nem seria ouvida [na justiça tradicional]. Com relação ao ofensor, quando uma pessoa se envolve num acidente, isso pode demonstrar uma certa irresponsabilidade social e a Justiça Restaurativa permite essa abordagem (Juiz atuante no caso).

Antes do encontro restaurativo, foram realizadas uma consulta restaurativa e um encontro preparatório com cada uma das partes. A vítima e o ofensor foram acompanhadas em todas as reuniões por suas mães, escolhidas como pessoas de apoio. A presença das mães, segundo uma das facilitadoras, intimidou um pouco as partes, especialmente no encontro restaurativo.

As mães estavam bem alteradas. Elas é que sustentam os filhos, então discutiram muito a questão da indenização. Eles até que foram participativos, mas falavam olhando pras mães, esperando aprovação (Facilitadora).

Ao longo do procedimento, a vítima e sua mãe reclamaram da falta de atenção do ofensor. Segundo a mãe, o ofensor não estava "dando a mínima" e não havia nem "ligado para saber se meu filho estava vivo", motivo pelo qual não esperava que fosse possível celebrar um acordo. $\mathrm{O}$ ofensor e sua mãe, por sua vez, insistiam que a vítima também deveria ser culpada pelo acidente, por "estar no meio da rua" quando ele ocorreu, alegando que os dois jovens seriam "vítimas". Segundo uma das facilitadoras, o ofensor, inicialmente, justificava-se a todo momento, negando que estivesse em alta velocidade, e apenas admitiu que também havia errado na segunda oportunidade em que se encontrou com as facilitadoras.

O encontro restaurativo não transcorreu de forma bem sucedida por duas razões. Em primeiro, lugar, os ânimos, já exaltados pelos desentendimentos a respeito da responsabilidade do ofensor, foram acirrados por um episódio ocorrido no dia anterior ao encontro. A vítima foi agredida por colegas do ofensor e, embora tenha ele afirmado que nada sabia sobre a agressão, o acontecido comprometeu a disposição das partes em relação a um possível acordo. Em segundo lugar, embora a vítima já tivesse anteriormente manifestado sua intenção de pleitear uma indenização, uma vez que teve de submeter-se a uma cirurgia e perdeu o emprego por conta do tempo que foi levada a se afastar para tratamento médico, o valor desse ressarcimento - estimado em $\mathrm{R} \$ 8.000,00$ - só foi 
apresentado na ocasião do encontro restaurativo e surpreendeu tanto o ofensor e sua mãe quanto as próprias facilitadoras.

A vítima foi atacada por colegas do autor no dia anterior ao encontro, estava machucada, e mesmo ele tendo dito que não sabia de nada, isso interferiu no encontro. Mas o motivo do fracasso foi o valor pedido da vítima. Nós não discutimos o valor nas outras reuniões, a gente até tomou um susto. O clima foi muito tenso, eu pensei que ia dar briga (Facilitadora).

Não foi possível às partes, assim, chegar a um acordo. As mães da vítima e do ofensor ficaram bastante ressentidas com as discussões travadas no encontro restaurativo e houveram por bem que o caso retornasse ao trâmite normal do Juizado Especial Criminal. De acordo com a mãe da vítima, a parte contrária se recusou a pagar a indenização pedida porque considerou mais vantajoso pagar apenas cestas básicas. A mãe do ofensor, no entanto, justificou a recusa sob o argumento de que o pagamento de uma indenização não corresponderia a uma autêntica punição ao filho, mas um prejuízo financeiro a ela própria.A mãe do ofensor enfatizou que o atropelamento foi um simples acidente, de modo a relativizar a responsabilidade do filho. De qualquer forma, ambas demonstraram confiança na correção do juiz.

Ele só veio procurar meu filho depois de muito tempo, só para oferecer remedinho (...). O que mais me chocou no encontro foi a mãe dele ter trazido um mapinha, dizendo que meu filho estava no meio da rua e que o filho dela não tinha culpa (...) Ela disse que preferia pagar cestas básicas. (...) Mesmo que o juiz decida contra a minha opinião, é a opinião dele que vale, é o juiz que dá a solução (Mãe da vítima).

O valor da indenização foi injusto, porque o que aconteceu foi um acidente, ele estava no meio da pista. (...) Fiquei muito chateada porque a mãe dele disse que o meu filho era um filhinho de papai, que nunca tinha trabalhado na vida. Espero que, com o caso voltando para o juiz, meu filho pague a pena fazendo trabalho comunitário. Não tem sentido eu pagar a indenização, porque, se fosse um crime, eu estaria pagando por um crime dele (Mãe do ofensor).

As facilitadoras atribuíram a ausência do acordo à elevada soma pedida pela parte e admitiram que, além de haver tratado da dimensão emocional do conflito, deviam ter também atentado para as questões materiais que despontaram do acidente. De qualquer 
modo, embora reconhecendo que não foi satisfatoriamente frutífera, as partes consideraram a experiência com a Justiça Restaurativa interessante. 


\section{Entre comunidade e sociedade}

\subsection{Brechas para a comunidade}

Embora pareça anacrônica, a volta da comunidade, como demonstrado por Bauman, tem seu sentido na modernidade reflexiva. Ela é, na verdade, um refúgio contra a insegurança provocada pela reflexividade e que responde, assim, a certos anseios generalizados na sociedade moderna. A Justiça Restaurativa, ao mobilizar as sensações evocadas pela ideia de comunidade, não é uma "anomalia" no contexto do direito penal contemporâneo - especialmente em meio às tendências de incremento do rigor punitivo (BOTTOMS, 2003), mas uma resposta a determinadas insatisfações não atendidas pela justiça criminal da sociedade.

A origem da Justiça Restaurativa mostra que ela surgiu para atender determinados tipos de conflitos que escapam aos moldes da espécie de conflitos para a qual foi desenhado o sistema de justiça tradicional. Assim, os nichos nos quais floresceu a Justiça Restaurativa foram, inicialmente, a Justiça da Infância e da Juventude e os crimes envolvendo membros de populações aborígenes. Trata-se de conflitos para os quais a justiça criminal não é capaz de oferecer soluções satisfatórias, precisamente porque estão, geralmente, impregnados de uma carga de pessoalidade que não é processada pelos trâmites impessoais da justiça tradicional e que, dessa forma, permanece latente como germe de conflituosidade ulterior.

A percepção das insuficiências da justiça tradicional com relação à resolução de certos tipos de conflitos é patente, como se viu, na fala da equipe do Projeto-piloto do Núcleo Bandeirante, na qual é unânime a referência às limitações do sistema de justiça criminal. Tais limitações são tão agudamente percebidas que, em geral, são concebidas como características intrínsecas ao direito - como se o direito, como campo de saber e técnica específica, não pudesse operar de outra forma senão com distância e impessoalidade e fosse necessário, assim, o socorro de outras áreas do conhecimento para torná-lo mais "humano". Daí a razão por que os operadores do direito entrevistados não enxergam diferenças significativas entre sua atuação em um processo comum e em um procedimento restaurativos - ou, às vezes, fazem mesmo questão de que sua imagem continue sendo aquela de autoridade afirmada pelo sistema de justiça tradicional. As 
peculiaridades da Justiça Restaurativa em face da justiça criminal, nas quais os operadores do direito vislumbram vantagens, são apreendidas por eles como aportes externos ao campo propriamente jurídico, a serem trazidas pelo concurso de outros profissionais. A relativização da impessoalidade do direito deve vir, na concepção da equipe, de fora e não de dentro do próprio direito.

Um dos motivos que explica esse tipo de pensamento é o fato de o direito promover a redução do conflito a seus aspectos meramente legais. Sobre essa questão, estudos de antropologia do direito, como o do antropólogo Max Gluckman, mostram que a forma como um conflito é resolvido está associada ao tipo de relacionamento social predominante em dada sociedade. Nas sociedades tradicionais, em que vigora um padrão de sociabilidade correspondente à noção de comunidade, as relações sociais são, como afirma Gluckman, relações multiplexas (multiplex relationships). Ele as descreve como " the structure of relationships in which a person tends to occupy the same position relative to the same set of other persons in all networks of purposive ties - economical, political, procreative, religious, educational" (GLUCKMAN, 1955, p. 19). ${ }^{33}$ Com esse conceito, Gluckman quer dizer que, em uma sociedade tradicional, cada indivíduo se apresenta, em cada e em toda relação social, como uma persona única e indivisa. Cada relação que mantém evoca necessariamente a posição que ele ocupa em relações que também protagoniza em outros níveis da vida social. Ao contrário, em sociedades modernas, cada tipo de relação pressupõe a exposição de somente uma das múltiplas facetas que compõem a persona do indivíduo, a qual se cinde conforme a natureza do relacionamento em questão. Por assim dizer, cada contato envolve a performance de um papel social distinto e não simultâneo. Em sociedades tradicionais, por conta da menor especialização das esferas da vida social, o indivíduo é sempre considerado na totalidade de suas relações sociais (como pai, como marido e como chefe político, por exemplo, de maneira concomitante).

O caráter multiplexo dos relacionamentos sociais de uma dada comunidade repercute sobre a forma como são resolvidos os seus conflitos. Ao estudar, por exemplo, os Barotse, da Rodésia do Norte, Gluckman percebe que a natureza multiplexa das relações que eram levadas às kutas, instituições que reuniam atribuições judiciais, políticas e administrativas, induzia à adoção, por parte dos membros da kuta, de uma postura

\footnotetext{
33 Tradução livre: "relacionamentos que servem muitos interesses" ou como "a estrutura de relacionamentos no qual uma pessoa tende a ocupar a mesma posição relativamente ao mesmo conjunto de pessoas em todas as redes de laços úteis - econômicas, políticas, procriativas, religiosas, educacionais".
} 
essencialmente conciliatória. Tendo em vista que conflitos pontuais, sobre interesses específicos, surgidos no seio de uma relação multiplexa tendem a se expandir e a comprometer a relação em sua totalidade - não raramente implicando o seu rompimento -, as kutas eram levadas a extrapolar as fronteiras da questão específica que havia motivado a sua intervenção e a considerar aspectos mais amplos da relação da qual o conflito havia emergido. Por assim dizer, para lidar com uma relação multiplexa, os membros da kuta eram obrigados a "broaden the field of their enquiries, and consider the total history of relations between the litigants, not only the narrow legal issue raised by one of them" $\left(\right.$ GLUCKMAN, 1955, p. 21) ${ }^{34}$. No caso de dois irmãos e seu tio, por exemplo, que disputavam o direito de uso de uma parcela de terra, questões paralelas, que não tinham relação direta com o litígio - mas que, claramente, haviam contribuído para agravar o clima de tensão entre as partes -, como o adultério cometido por um primo, filho desse tio, com a mulher de um dos irmãos, foram aventadas e consideradas pelos membros da kuta (ibid., p. 47). Gluckman nota que, quanto mais próxima a relação entre os litigantes, mais os membros da kuta estão dispostos a alargar seu âmbito de consideração. Sua meta, com esse alargamento, é eliminar todo e qualquer ponto de atrito que esteja ameaçando a continuidade daquela relação, viabilizando uma convivência amigável entre as partes no futuro. Daí que, para tanto, privilegiem soluções conciliatórias, do tipo minimax, isto é, soluções que busquem maximizar os pontos de entendimento entre as partes através da minimização da distância existente entre seus pontos de desentendimento, preferindo-se a via do compromisso entre as pretensões opostas apresentadas, em detrimento de soluções do tipo soma-zero, em que essa distância é reforçada e uma das partes sai como ganhadora e a outra como perdedora (SANTOS; MARQUES; PEDROSO, 1996, pp. 52-53).

Nas sociedades modernas, em que as relações multiplexas tendem a se desintegrar, o âmbito de apreciação judicial não alcança todas as dimensões o relacionamento entre as partes, limitando-se pontualmente a aspectos do conflito que sejam juridicamente relevantes. Quando as partes não se conhecem, seu relacionamento geralmente não ultrapassa as repercussões jurídicas do conflito que as envolveu. Assim, tendo em vista que a maior parte dos contatos, em uma sociedade moderna são aqueles entre estranhos, a redução do espectro judicial às particularidades técnicas do conflito é suficiente para

34 Tradução livre: “ampliar o campo de sua investigação, e considerar a história total de relações entre os litigantes, não apenas a estreita questão legal levantada por um deles”. 
equacioná-lo. Entretanto, quando as partes têm um relacionamento pré-existente, a consideração, apenas, da dimensão jurídica do conflito instalado entre elas nem sempre é bastante para realmente superá-lo e para garantir a continuidade do relacionamento.

A solução oferecida pelo sistema de justiça tradicional, assim, não é satisfatória para aqueles tipos de relacionamento que ainda retêm um caráter minimamente multiplexo, nos quais, por conta da proximidade entre as partes, é preciso levar em conta mais do que a faceta estritamente jurídica do conflito, bem como tratar de garantir a continuidade da relação. O caso dos concunhados é um bom exemplo: uma apreciação restrita aos aspectos penais do conflito certamente não seria capaz de solucioná-lo, já que o conflito entre os concunhados tinha uma dimensão muito mais profunda do que a meramente jurídica. Essa lacuna deixada pela justiça tradicional foi a brecha pela qual a Justiça Restaurativa pôde se insinuar no sistema de justiça.

A inaptidão do sistema de justiça em oferecer soluções satisfatórias é uma das faces da crise de legitimidade do sistema penal. Entendendo-se como legitimidade a conformidade da prática com o discurso jurídico-penal, a crise de legitimidade do sistema penal ocorre, justamente, no momento em que a falsidade do discurso jurídico-penal ganha evidência (ZAFFARONI, 2001). Esse momento coincide com o surgimento da chamada criminologia da reação social, na década de sessenta do século passado, que detonou a formulação de severas críticas ao sistema penal, incluindo-se ao esquema de funcionamento da justiça criminal. O aumento dos índices de criminalidade, ocorrido em várias partes do mundo nos últimos anos, acentuou a crise, demonstrando que os mecanismos pelos quais opera o sistema penal são, em realidade, incapazes de coibir o crime, uma promessa demasiadamente frágil para servir de justificativa à sua existência. Ao prometer o que a justiça criminal não foi capaz de cumprir, isto é, oferecer soluções satisfatórias para conflitos penais, a Justiça Restaurativa é apresentada como uma resposta à crise de legitimidade do sistema penal. É sob essa perspectiva, como visto, que o Ministério da Justiça adotou e ideia e passou a capitanear a promoção da Justiça Restaurativa no Brasil. Assim, da mesma forma que a volta da comunidade é um subproduto do aprofundamento da sociedade na modernidade reflexiva, o aparecimento da Justiça Restaurativa pode ser entendido como um subproduto da crise de legitimidade do sistema penal. 


\subsection{Investidas da sociedade}

Se por um lado, há um certo espaço aberto à comunidade na sociedade reflexiva, por outro, a sua existência encerra uma série de contradições. Essas contradições contaminam a Justiça Restaurativa, obrigando-a a operar em meio a uma série de paradoxos (PAVLICH, 2005).

O mais patente deles radica no fato de que é pela mão do Estado que a comunidade é forjada na Justiça Restaurativa. A comunidade não pré-existe ao procedimento restaurativo; ela é, na maior parte das vezes, artificialmente montada quando o sistema de justiça criminal encaminha um determinado caso à Justiça Restaurativa e o procedimento restaurativo tem início. Tönnies, como visto, descreve o Estado como um ente da sociedade, que garante mecanicamente a sua unidade na ausência dos vínculos orgânicos da comunidade. $\mathrm{O}$ que a Justiça Restaurativa propõe é criar esses vínculos orgânicos a partir da ação mecânica do Estado, o que retira da comunidade o componente de espontaneidade que a define. A comunidade formada empresta do Estado sua tinta coercitiva e, mais além disso, é instrumentalizada por ele para a obtenção de um ganho de legitimidade na administração da justiça estatal, por meio da maior "eficiência"e da maior "acessibilidade" buscadas pelo Ministério da Justiça no seio apoio a programas de Justiça Restaurativa. $^{35}$

É porque a Justiça Restaurativa não prescinde da coerção estatal que a equipe do Projeto-Piloto do Núcleo Bandeirante acredita que a Justiça Restaurativa não é uma alternativa à justiça tradicional, mas um mero complemento. Essa visão é comum entre os próprios restaurativistas, que não reputam incompatíveis a restauração e a punição, como é o caso, apenas para citar alguns exemplos, de Lode Walgrave, para quem a punição, entendida como qualquer medida com caráter impositivo, é um meio e a restauração um fim (WALGRAVE, 2003), de Anthony Duff, para quem a Justiça Restaurativa não é uma alternativa à punição, mas uma punição alternativa (DUFF, 1992) e de John Braithwaite, para quem a perspectiva de punição, como medida de último recurso na escalada de sua pirâmide regulatória, confere à Justiça Restaurativa uma aura de inexorabilidade que

${ }^{35}$ A busca pela "eficiência" provavelmente é o motivo pelo qual, atualmente (segundo dados colhidos em janeiro de 2009), o Projeto-Piloto de Justiça Restaurativa do Núcleo Bandeirante esteja realizado "encontros restaurativos conjuntos", à semelhança do que ocorre com freqüência nos Juizados Especiais Criminais (REALE Jr., 2008). Ver o questionário de atualização de dados sobre o Projeto-Piloto de Justiça Restaurativa do Núcleo Bandeirante anexado ao fim do trabalho. 
assegura bons resultados: "Put another way, my hypothesis is that restorative justice works best with a specter of punishment in the background (BRAITHWAITE, 2002, p. 35). ${ }^{36}$

A compatibilidade entre restauração e punição depende, na realidade, de como se define punição. Álvaro Pires, ao afirmar que todo conceito se constrói a partir de uma distinção, oferece duas distinções interessantes a partir das quais se obtêm definições diferentes de punição. A primeira distinção é a que se faz entre punição e recompensa. Sob esse ponto de vista, são ambas formas de comunicar algo a respeito de uma ação passada a punição é uma reprovação e, portanto, reporta-se a uma ação repreensível, ao passo que a recompensa é uma aprovação e refere-se, contrariamente, a uma ação louvável. Se a punição é, assim definida, uma maneira de expressar reprovação, qualquer meio apto para expressá-la enquadra-se na definição de punição. Pires diz que, nesse sentido, mesmo uma reparação pode ser considerada uma punição, uma vez que comunica que a ação à qual ela responde é repreensível. No entanto, se a punição é definida na chave da distinção existente entre compensação e sofrimento, a punição é uma resposta que, diferentemente da reparação, implica sempre um sofrimento a ser impingido àquele que é alvo dela. Dessa forma, a reparação restaria excluída do conceito de punição (PIRES, 2005).

Assim, se adotada a primeira definição, a Justiça Restaurativa pode perfeitamente enquadrar-se no marco do direito penal, sem que sua presença seja apontada como um fator de desfiguração do direito penal ou que se possa dizer que a identidade do direito penal esteja ameaçada pela assimilação de elementos tipicamente exclusivos do direito civil. Ocorre que, no imaginário de todos os entrevistados, a punição está definida nos termos da segunda distinção e a noção de pena está indissociavelmente relacionada com a de sofrimento. É por isso que o esquema mental dos membros da equipe do projeto-piloto operam sempre à luz de uma suposta dicotomia existente entre a Justiça Restaurativa e a justiça tradicional suas falas enfatizam as profundas diferenças que creem haver entre elas. Nenhum dos entrevistados, com efeito, parece enxergar pontos de contato entre ambas as formas de funcionar da justiça criminal, preferindo caracterizá-las como instâncias estanques, em que vigoram métodos totalmente diferentes. Esse tipo de percepção, que Pires descreve como um "obstáculo epistemológico" à evolução do direito penal - ou como uma "causa cognitiva" da sua não evolução (PIRES, 2005) - leva a que, de fato, a

${ }^{36}$ Tradução livre: "Dizendo de outra maneira, minha hipótese é a de a justiça restaurativa funciona melhor com o espectro da punição ao fundo". 
Justiça Restaurativa se resigne a ser um mero complemento da justiça criminal tradicional, já que a separação a deixa intocada e restringe as possibilidades de mudanças estruturais do sistema penal ao círculo de fronteiras bem definidas ocupado pelas práticas restaurativas.

Na prática, a Justiça Restaurativa e a justiça tradicional não são tão diferentes nem sob o aspecto do sofrimento. A subordinação da Justiça Restaurativa à rationale da vergonha reintegrativa, tal como proposto como John Braithwaite, subestima a carga de sofrimento embutida no sentimento de vergonha (MATTHEWS, 2006) e ignora seu ingrediente impositivo. Lançando luz sobre o caráter coercitivo da Justiça Restaurativa, Annalise Accorn a qualifica como um oxímoro, uma vez que fundada em uma "compaixão compulsória": "Restorative justice, rather than relying on spontaneous compassion (which (...) has little relation to justice) relies on the possibility of inculcating in its participants a morally elevated practice of compassion" (ACCORN, 2004, p. 137) ${ }^{37}$. De acordo com ela, a Justiça Restaurativa obriga as partes a mobilizarem em relação a estranhos os mesmos sentimentos que costumam dedicar apenas a pessoas de quem são próximas:

(...) our sense of the appropriate response to an armed robber would be different if we were married to the robber or if he were our best friend.

Thus restorative justice now asks us to view the offender through the eyes of personal love. (...) restorative justice here seeks to access our personal feelings of love for our family and friends and to transfer hypothetically and imaginatively those intimate and affectionate feelings onto the offender (ibid., p. 63). ${ }^{38}$

A necessidade de demonstrar sentimentos pessoais em relação a pessoas com quem não se tem, em geral, intimidade, não é capaz de criar comunidades autênticas. No curso do processo restaurativo, formam-se, em realidade, comunidades a que Bauman chama “comunidades de chapelaria" ou "comunidades de carnaval". Por instantes determinados, os participantes comungam ao exporem catarticamente suas emoções mais pessoais e, no dizer de Sennett, intercambiarem sentimentos; uma vez terminada a sessão, no entanto, retornam todos às suas vidas particulares, sem que nenhum laço efetivamente duradouro

\footnotetext{
${ }^{37}$ Tradução livre: “A Justiça Restaurativa, em vez de se basear na compaixão espontânea (que tem (...) pouca relação com a justiça), baseia-se na possibilidade de inculcar nos participantes uma prática da compaixão mais moralmente elevada.

${ }^{38}$ Tradução livre"(...) nosso senso a respeito da resposta apropriada a um roubo a mão armada seria diferente se fossemos casados com o assaltante ou se ele fosse nosso melhor amigo. Assim, a justiça restaurativa nos pede que vejamos o ofensor pelos olhos do amor pessoal. (...) a justiça restaurativa procura acessar nossos sentimentos pessoais de amor por nossa família e amigos e transferir hipotética e imaginariamente esses sentimentos íntimos e afetuosos ao ofensor".
} 
tenha-se tecido entre eles. Como visto com Giddens, os relacionamentos sociais, na atualidade, tendem a assumir a forma de relações puras, cuja principal característica é a possibilidade de fácil rompimento. Seguindo esse padrão, a experiência restaurativa não é capaz de gerá-los senão durante o momento fugaz em que se realizam os encontros, especialmente se não existem vínculos anteriores.

As emoções compartilhadas não são suficientes para transformar relações distanciadas, entre estranhos, em relações de proximidade. Entre estranhos, as mediações características da modernidade, sobretudo a ficha simbólica representada pelo dinheiro, têm maior peso do que a reciprocidade de sentimentos. Por mais que os facilitadores tenham insistido que as partes, em todos os casos analisados, priorizassem a expressão de suas emoções, discussões de ordem prática a respeito de valores financeiros sempre vinham a tona. No caso do atropelamento, discordâncias em torno de questões financeiras foram a causa do fracasso do encontro restaurativo. Na consulta, no encontro preparatório e no encontro restaurativo observados, grande parte do tempo foi dominada por discussões sobre eventuais reparações econômicas. Mesmo no caso dos concunhados, o dinheiro se fez presente, como o elemento esgarçou uma relação de proximidade e detonou o conflito, demonstrando que mesmo um relacionamento familiar hoje se reveste de características das chamadas "relações puras" e pode romper-se de acordo com as circunstâncias. Enfim, nas entrevistas, alguns dos próprios membros da equipe do programa reconheceram que questões financeiras são pelo menos tão relevantes no desfecho dos casos quando a reparação emocional.

Outros elementos próprios à sociedade perturbam a ideia de comunidade proposta pela Justiça Restaurativa. Como enfatiza Braithwaite, a efetividade da Justiça Restaurativa pressupõe a existência de um certos consenso entre as partes, especialmente em relação ao caráter criminoso de determinados conflitos. No caso do atropelamento, fica claro que esse consenso nem sempre existe - para a mãe da vítima, tratava-se de um delito, para a mãe do ofensor, tratava-se de um simples acidente. Além disso, mesmo se fossemos considerar apenas os chamados crimes predatórios de Braithwaite, é preciso admitir que a obtenção do consenso é fácil no contexto de homogeneidade social da comunidade, mas muito difícil no cenário diversificado da sociedade, sobretudo diante de clivagens de classe. Tais clivagens se mostraram no caso do atropelamento, em que a mãe da vítima ressaltou, na sua fala as 
diferenças sociais existentes entre ela e seu filho e o ofensor e sua mãe - sem dúvida, tratou-se de um ponto importante na desavença entre as partes.

Também é bastante curioso que alguns dos elementos que os teóricos da Justiça Restaurativa sublinham como sendo tributários da noção de comunidade sejam, na verdade, produtos da modernidade reflexiva. A vergonha, a que Braithwaite credita uma habilidade reintegrativa, não tem como agente responsável pela sua inculca a comunidade, como se supõe, mas, como discorre Giddens, o próprio indivíduo, quando assume como objeto de um exercício reflexivo sua autoidentidade e conclui que sua atuação não guarda correspondência com a ideia que tem de si próprio. Ademais, a usual descrição da Justiça Restaurativa como uma filosofia de vida, a ser aplicada em todas as situações da vida, não é simplesmente uma tentativa de retomar a perspectiva holística da vida em comunidade, mas implica, sobretudo, a adoção de um estilo de vida, uma atitude, conforme Giddens, típica da sociedade reflexiva. Participar de uma comunidade, na modernidade reflexiva, não significa estar em comunhão espontânea com outros, como na descrição de Tönnies, mas optar, refletidamente, por fazer parte de um dado grupo de pessoas que leva um certo estilo de vida.

É a complexidade de se compreender o lugar da comunidade na modernidade é a razão que explica por que a ideia de comunidade, mesmo para os restaurativistas, não é tão intuitiva. A dificuldade de definir o que é a comunidade em situações concretas é tão significativa que a equipe não foi capaz de fazê-lo nem mesmo, no caso do atropelamento, diante de um abaixo-assinado de moradores, que listava nominalmente possíveis membros de uma comunidade local, com um histórico de significativa mobilização pela legalização de sua situação de moradia.

A indefinição a respeito do papel representado pela comunidade na Justiça Restaurativa vem dos paradoxos que a governam. O caráter paradoxal da Justiça Restaurativa deriva das investidas realizadas pela sociedade - pelo Estado, pelo dinheiro, pela reflexividade como um todo - contra a noção de comunidade que subjaz ao ideal restaurativo. Investidas da mesma sociedade que, ironicamente, deu margem ao retorno da comunidade na atualidade. 


\section{Conclusão}

Como bem notado por Bottoms (BOTTOMS, 2003), grande parte dos teóricos da Justiça Restaurativa, quando tratam de persuadir o leitor das suas vantagens em relação à chamada justiça retributiva, afirma que o ideal restaurativo esteve presente na maioria dos sistemas de resolução de conflitos ao longo da história (p. ex. BRAITHWAITE, 2003). Essa tese da quase universalidade da Justiça Restaurativa, que serve como justificativa para a defesa do modelo restaurativo na atualidade, é demonstrada sempre em alusão a sociedades tradicionais e situa, no advento da modernidade, um momento de anormal subversão de uma lógica de solução de conflitos reputada como a mais "natural". Mesmo que se considere como verdadeiro o argumento de que o ideal restaurativo tenha sido mais duradouro, historicamente, que a sua contraparte retributiva, ideia que por si exigiria uma análise mais cuidadosa do que simples afirmações, tais autores não se dão conta de que se o modelo restaurativo não tem hoje o mesmo destaque que possa ter tido em outros momentos históricos, deve haver uma razão para tanto. Aborda-se a Justiça Restaurativa como um modelo apropriado a qualquer contexto, quando, em realidade, o que vimos no presente trabalho é que as significativas diferenças existentes entre comunidade e sociedade refletem-se em demandas de modelos de justiça distintos e a Justiça Restaurativa só está bem equipada para responder certos tipos de conflitos.

Aqueles que integram a experiência da Justiça Restaurativa intuem essa diferença. O ofensor do caso dos concunhados e uma das facilitadoras demonstraram suas dúvidas quanto à aplicabilidade da Justiça Restaurativa à generalidade dos casos e a equipe do projeto-piloto tem a existência de vínculos anteriores ao conflito como um critério preponderante da seleção de casos. Por mais que haja relatos de casos bem-sucedidos envolvendo estranhos, o modo pelo qual opera a Justiça Restaurativa, ao se valer das emoções como sua matéria-prima, é mais adequado quando já existem sentimentos pessoais vinculando as partes. As relações de proximidade, entendidas como aquelas carregadas de afetividade e geralmente expressas em laços familiares, de amizade ou de vizinhança, que correspondem à ligação orgânica da Gemeinschaft, demandam um método de solução de conflitos capaz de abordar aspectos da questão que vão além da dimensão jurídico-penal do delito e, nesse caso, a Justiça Restaurativa é ideal. Entretanto, aqueles conflitos que supõem relações distanciadas - em especial aquelas que venham a ser 
mediadas pela ficha simbólica do dinheiro -, típicos da Gesellschaft, nem sempre são sensíveis ao modo de operação da Justiça Restaurativa. Soluções conciliatórias que tenham como finalidade restaurar relações tendem a ser preferidas quando essas relações têm de ser continuadas, como ocorre nas relações de proximidade; as relações distanciadas, diferentemente, são relações caracteristicamente efêmeras ou pontuais e, assim, podem prescindir desse tipo de preocupação. A Justiça Restaurativa, na visão de alguns, aspira a criar comunidades, transformando relações distanciadas em relações de proximidade, mas fazê-lo é uma contradição em termos: uma comunidade que não surge espontaneamente, mas por força de uma intervenção estatal, não é propriamente uma comunidade. É, no máximo, uma comunidade de chapelaria, como descreve Bauman.

O caráter limitado do presente trabalho, que analisou em profundidade apenas alguns casos de um programa específico de Justiça Restaurativa não permite que nossa conclusão seja tomada como uma verdade peremptória. Há, é claro, relatos de casos que, não obstante envolvessem estranhos, foram bem-sucedidos - geralmente aqueles em que houve significativos traumas emocionais. De qualquer maneira, o presente estudo coloca em dúvida o uso indiscriminado da Justiça Restaurativa e levanta a questão do porquê o modelo restaurativo tem sido encarado com tanto otimismo e mesmo incentivado pelas instâncias governamentais.

Concluímos que a Justiça Restaurativa, no que concerne a certos conflitos, pode ser, de fato, "uma ideia fora do lugar", na expressão utilizada pelo crítico Roberto Schwarz. Quando Schwarz analisou o lugar do liberalismo no Brasil do século XIX e o descreveu como uma "ideia fora do lugar", não deixou de perceber que a assimilação das ideias liberais muitas vezes se prestava, paradoxalmente, a conferir um verniz liberal a práticas marcadamente antiliberais, servindo-lhes como justificação. Algo similar ocorre com a Justiça Restaurativa: trata-se de um método de resolução de conflitos que se funda na noção de comunidade, mas que é, também paradoxalmente, chamado hoje a resolver um problema típico da sociedade, isto é, a crise de legitimidade do sistema de justiça criminal.

Como visto, alguns participantes reclamaram da postura do juiz na audiência anterior ao encaminhamento do caso à Justiça Restaurativa e quase todos mostraram-se bastante satisfeitos com a experiência restaurativa. Mesmo no caso do atropelamento, em que as partes preferiram confiar o desfecho ao juiz, houve elogios à Justiça Restaurativa. Ao prover soluções satisfatórias para toda uma gama de conflitos - aqueles envolvendo 
relações de proximidade -, para os quais a justiça tradicional não oferecia respostas, a Justiça Restaurativa relativiza a crítica da ineficácia do sistema de justiça criminal. Ela tende a ser, de fato, bastante efetiva nesses casos. Ocorre, no entanto, que mesmo sendo ineficaz quanto aos demais casos - aqueles envolvendo relações distanciadas -, a Justiça Restaurativa causa um boa impressão naqueles que fazem uso dela. Diferentemente da justiça tradicional, ela oferece oportunidades de fala e de escuta que são importantes em qualquer tipo de caso. Mesmo que falhe, as partes estarão mais bem preparadas para receber qualquer solução determinada posteriormente pelo juiz, no seguimento normal do processo penal, e sentirão a sentença como mais justa. Isso, provavelmente, explica o empenho do Ministério da Justiça brasileiro na consolidação da Justiça Restaurativa no país: trata-se de uma reforma no Poder Judiciário que realmente pode trazer dividendos políticos sob a forma da maior satisfação da clientela da justiça.

A Justiça Restaurativa é muito promissora, mas é preciso saber em que casos aplicá-la. Ainda há lugar para a comunidade na sociedade, porém é utópico pretender modelar toda a sociedade à imagem da comunidade. A Justiça Restaurativa não é capaz, por si só, de forjar um padrão de sociabilidade cujo espaço é cada vez mais restrito na modernidade reflexiva. Talvez, no entanto, possamos aproveitar algo mais dela e, descarregando-a de seu componente emocional - da compaixão compulsória, segundo a terminologia de Annalise Acorn -, utilizarmos sua abertura dialógica para pensar uma nova forma de fazer justiça criminal, concebendo-a não na chave da "política-vida" de Giddens, como simplesmente uma forma de solução de conflitos íntimos interpessoais, mas na da "Política com P maiúsculo" de Bauman, como uma opção ampla de política criminal endereçada à transformação do sistema de justiça penal como um todo. 


\section{Bibliografia}

ACORN, Annalise. Compulsory Compassion: a Critique of Restorative Justice. Vancouver: University of British Columbia Press, 2004.

AZEVEDO, Rodrigo Ghiringhelli de. Informalização da justiça e controle social: estudo sociológico da implantação dos Juizados Especiais Criminais em Porto Alegre. São Paulo: IBCCRIM, 2000.

BABBIE, Earl. Métodos de pesquisa de survey. Belo Horizonte: UFMG, 2005.

BASTOS, Márcio Thomaz. Apresentação. In: SLAKMON, Catherine; MACHADO, Maíra Rocha; BOTTINI, Pierpaolo Cruz (orgs.). Novas direções na governança da justiça e da segurança. Brasília: Ministério da Justiça, 2006, p. 15.

BAUMAN, Zygmunt. In search of politcs. Stanford: Stanford University Press, 1999. Modernidade líquida. Rio de Janeiro: Jorge Zahar, 2001.

Amor líquido: sobre a fragilidade dos laços humanos. Rio de Janeiro: Jorge Zahar, 2004.

. Community: seeking safety in an insecure world. $7^{\text {a }}$ ed. Cambridge: Polity, 2007.

BAZEMORE, Gordon; WALGRAVE, Lode. Restorative Juvenile Justice. Monsey: Criminal Justice Press, 1999.

BECK, Ulrich. A reinvenção da política: rumo a uma teoria da modernização reflexiva. In: GIDDENS, Anthony; BECK, Ulrich; LASH, Scott. Modernização reflexiva: política, tradição e estética na ordem social moderna. São Paulo: Editora da UNESP, 1997, pp. 1171.

La sociedad del riesgo: hacia una nueva modernidad. Barcelona: Surcos, 2006. 
BOTTOMS, Anthony. Some sociological reflections on Restorative Justice. In: HIRSCH, Andrew von; ROBERTS, Julia; BOTTOMS, Anthony E.; ROACH, Kent; SCHIFF, Mara (eds.) Restorative Justice \& Criminal Justice: competing or reconcilable paradigms? Portland: Hart Publishing, 2003, pp. 79-114.

BRAITHWAITE, John. Crime, shame and reintegration. New York: Cambridge University Press, 1999.

. Restorative Justice and Responsive Regulation. New York: Oxford University Press, 2002.

. Principles of Restorative Justice. In: HIRSCH, Andrew von; ROBERTS, Julia; BOTTOMS, Anthony E.; ROACH, Kent; SCHIFF, Mara (eds.) Restorative Justice \& Criminal Justice: competing or reconcilable paradigms? Portland: Hart Publishing, 2003, pp. 1-20.

CAHNMAN, Werner J. Tönnies e a teoria das mudanças sociais: uma reconstrução. In: MIRANDA, Orlando de (org.) Para ler Ferdinand Tönnies. São Paulo: EDUSP, 1995, pp. 87- 102.

CARVALHO, Salo de; WUNDERLICH, Alexandre (orgs.). Diálogos sobre a justiça dialogal. Rio de Janeiro: Lumen Juris, 2002.

; ___ (orgs.). Novos diálogos sobre os Juizados Especiais Criminais. Rio de Janeiro: Lumen Juris, 2005.

COSTA, Sérgio. Dois Atlânticos: teoria social, anti-racismo, cosmopolitismo. Belo Horizonte: Editora da UFMG, 2006. Fragmento em versão eletrônica.

DOMINGUES, José Maurício. Reflexivity, individualism and modernity. 2004. Disponível em http://www.iuperj.br/quemsomos/corpodocente/jdomingues/09.pdf. Acesso em outubro de 2007. 
DUFF, Anthony. Alternatives to Punishment or Alternative Punishment?. In: Craig, W. (ed.). Retributivism and its critics. Stuttgard: Steinder, 1992.

DURKHEIM, Émile. Uma resenha de Ferdinand Tönnies, Gemeinschaft und Gesellschaft: Abhandlung des Communismus und des Socialismus als empirischer Kulturformen. In: MIRANDA, Orlando de (org.) Para ler Ferdinand Tönnies. São Paulo: EDUSP, 1995 [1889], pp. 113-118.

. Da divisão do trabalho social. $2^{\text {a }}$ ed. São Paulo: Martins Fontes, 1999 [1893].

FARIA, José Eduardo. O sistema brasileiro de Justiça: experiência recente e futuros desafios. Estudos Avançados. São Paulo, vol. 18, n 51, 2004, pp. 103-126.

FOUCAULT, Michel. Vigiar e punir: nascimento da prisão. 26 ed. Petrópolis: Vozes, 2002 [1975].

FROESTAD, Jan; SHEARING, Clifford. O modelo Zwelenthemba de resolução de conflitos. In: SLAKMON, Catherine; DE VITTO, Renato Campos Pinto; PINTO, Renato Sócrates Gomes (orgs.). Justiça Restaurativa: coletânea de artigos. Brasília: Ministério da Justiça e Programa das Nações Unidas para o Desenvolvimento, 2005, pp. 79-124.

GIDDENS, Anthony. As consequências da modernidade. São Paulo: Editora da UNESP, 1991.

A vida em uma sociedade pós-tradicional. In: GIDDENS, Anthony; BECK, Ulrich; LASH, Scott. Modernização reflexiva: política, tradição e estética na ordem social moderna. São Paulo: Editora da UNESP, 1997, pp. 73-133.

. Modernidade e identidade. Rio de Janeiro: Jorge Zahar, 2002.

GLUCKMAN, Max. The judicial process among the Barotse on Northern Rodhesia. Manchester: Manchester University Press, 1955.

HOLSTON, James. A cidade modernista: uma crítica de Brasília e sua utopia. São Paulo: Companhia das Letras, 1993. 
JACCOUD, Mylène. Princípios, Tendências e Procedimentos que cercam a Justiça Restaurativa. In: SLAKMON, Catherine; DE VITTO, Renato Pinto de; PINTO, Renato Sócrates Gomes (orgs.). Justiça Restaurativa: coletânea de artigos. Brasília: Ministério da Justiça, 2005, pp. 163- 188.

KARAM, Maria Lúcia. Juizados Especiais Criminais: a concretização antecipada do poder de punir. São Paulo: Revista dos Tribunais, 2004.

LASH, Scott. A reflexividade e seus duplos: estrutura, estética e comunidade. In: GIDDENS, Anthony; BECK, Ulrich; LASH, Scott. Modernização reflexiva: política, tradição e estética na ordem social moderna. São Paulo: Editora da UNESP, 1997, pp. 135206.

LIEBERSON, Stanley. Small N's and big conclusions: an examination of the reasoning in comparative studies based on a small number of cases. In: RAGIN, Charles; BECKER, Howard (orgs.). What is a case: exploring the foundations of social inquiry. Cambridge: Cambridge University Press, 1992, pp. 105-118.

LUKÁCS, Georg. Ferdinand Tönnies e a fundamentação da nova escola sociológica alemã. In: MIRANDA, Orlando de (org.) Para ler Ferdinand Tönnies. São Paulo: EDUSP, 1995, pp. $135-142$.

MARSHALL, Tony F. Restorative Justice: an overview. London: Home Office Research Development Statistics Directorate. Disponível em http://www.homeoffice.gov.uk/rds/pdfs/occ-resjus.pdf.

MARX, Karl. O Capital: crítica da economia política. Rio de Janeiro: Civilização Brasileira, 1975 [1867]. Livro Primeiro Volume I.

MATTHEWS, Roger. Reintegrative shaming and restorative justice: reconciliation or divorce? In: AERTSEN, Ivo; DAEMS, Tom; ROBERT, Luc (eds.). Institutionalizing Restorative Justice. Portland: Willan, 2006, pp. 237-260. 
MAXWELL, Gabrielle. A Justiça Restaurativa na Nova Zelândia. In: SLAKMON, Catherine; DE VITTO, Renato Campos Pinto; PINTO, Renato Sócrates Gomes (orgs.). Justiça Restaurativa: coletânea de artigos. Brasília: Ministério da Justiça e Programa das Nações Unidas para o Desenvolvimento, 2005, pp. 281-296.

McCOLD, Paul; WACHTEL, Ted. Community is not a place: a new look at Community Justice. In: JOHNSTONE, Gerry (ed.). A Restorative Justice Reader. Cullompton: Willan, 2003, pp. 294-303.

MIRANDA, Orlando de. A dialética da identidade em Ferdinand Tönnies. In: (org.) Para ler Ferdinand Tönnies. São Paulo: EDUSP, 1995a, pp. 61-72.

. O conceito de racionalidade em Ferdinand Tönnies. In: (org.) Para ler Ferdinand Tönnies. São Paulo: EDUSP, 1995b, pp. 143-162.

PAVLICH, George. Governing paradoxes of Restorative Justice. London: GlassHouse Press, 2005.

PINTO, Renato Sócrates Gomes. Justiça Restaurativa: o paradigma do encontro. In: Justiça Restaurativa: um caminho para os direitos humanos?. Porto Alegre: Instituto de Acesso à Justiça, 2004, p. 55-75.

PIRES, Álvaro. Intervenção relativa à Mesa 4: A face bélica das formações sociais do capitalismo pós-industrial e globalizado: do sistema penal regular à eliminação das garantias dos direitos fundamentais - as sombrias perspectivas a partir de Guantánamo. In: KARAM, Maria Lúcia (org.). Globalização, sistema penal e ameaças ao Estado Democrático de Direito. Rio de Janeiro: Lumen Juris, 2005, pp. 191-220.

PRATT, John. Beyond evangelical criminology: the meaning and significance of restorative justice. In: AERTSEN, Ivo; DAEMS, Tom; ROBERT, Luc (eds.). Institutionalizing Restorative Justice. Portland: Willan, 2006, pp.44-67. 
RAGIN, Charles. Introduction: Cases of "What is a case?". In: RAGIN, Charles; BECKER, Howard (orgs.). What is a case: exploring the foundations of social inquiry. Cambridge: Cambridge University Press, 1992, pp. 1-17.

RAUPP, Mariana; BENEDETTI, Juliana Cardoso. A implementação da Justiça Restaurativa no Brasil: uma avaliação dos programas de Justiça Restaurativa de São Caetano do Sul, Brasília e Porto Alegre. Revista Ultima Ratio. Rio de Janeiro, a. 1, n. 1, 2007, pp. 3-36.

REALE Jr., Miguel. Simplificação processual e desprezo ao Direito Penal. Trabalho apresentado no Departamento de Filosofia do Direito da Faculdade de Direito da Universidade de Munique, 2008.

RENAULT, Sérgio Rabello Tamm; LOPES, Carlos. Apresentação. In: SLAKMON, Catherine; DE VITTO, Renato Campos Pinto; PINTO, Renato Sócrates Gomes (orgs.). Justiça Restaurativa: coletânea de artigos. Brasília: Ministério da Justiça, 2005, pp. 11-12.

ROLIM, Marcos. Justiça Restaurativa: para além da punição. In: Justiça Restaurativa: um caminho para os direitos humanos?. Porto Alegre: Instituto de Acesso à Justiça, 2004, pp. 7-32.

ROSANVALLON, Pierre. La crisis del Estado providencia. Madrid: Civitas, 1995.

RUESCHEMEYER, Dietrich. Can one or a few cases yield theoretical gains? In: MAHONEY, James; RUESCHEMEYER, Dietrich (eds.). Comparative historical analysis in the Social Sciences. New York: Cambridge University Press, 2003, pp. 305-336.

SADEK, Maria Tereza. Controle externo não resolve os problemas do Judiciário. Entrevista concedida a Frederico de Vasconcelos. Folha de S. Paulo, 10 de novembro de 2003. Disponível em http://clipping.planejamento.gov.br/Noticias.asp?NOTCod=89925. . Judiciário: mudanças e reformas. Estudos Avançados. São Paulo, vol. 18, n 51, 2004, pp. 79-101. 
SANTOS, Boaventura de Sousa; MARQUES, Maria Manuel Leitão; PEDROSO, João. Os tribunais nas sociedades contemporâneas. Revista Brasileira de Ciências Sociais. São Paulo, n. 30, a. 11. fev. 1996, pp. 29-62.

SCHWARZ, Roberto. Ao vencedor as batatas: forma literária e processo social nos inícios do romance brasileiro. São Paulo: Duas Cidades, 1977.

SCURO NETO, Pedro. Por uma Justiça Restaurativa "real e possível". In: Justiça Restaurativa: um caminho para os direitos humanos?. Porto Alegre: Instituto de Acesso à Justiça, 2004, p. 33-44.

O enigma da esfinge: dez anos de Justiça Restaurativa no Brasil. Revista IOB de Direito Penal e Processo Penal. Porto Alegre, vol. 8, n 8, fev./mar. 2008, pp. 163-184.

SENNETT, Richard. O declínio do homem público: as tiranias da intimidade. São Paulo: Companhia das Letras, 1988.

A corrosão do caráter: consequências pessoais do trabalho no novo capitalismo. $10^{\mathrm{a}}$ ed. Rio de Janeiro: Record, 2005.

SHAPLAND, Joanna. Restorative Justice and Criminal Justice: just responses to crime? In: HIRSCH, Andrew von; ROBERTS, Julia; BOTTOMS, Anthony E.; ROACH, Kent; SCHIFF, Mara (eds.) Restorative Justice \& Criminal Justice: competing or reconcilable paradigms? Portland: Hart Publishing, 2003, pp. 195-218.

SICA, Leonardo. Bases para o modelo brasileiro de Justiça Restaurativa. In: SLAKMON, Catherine; MACHADO, Maíra Rocha; BOTTINI, Pierpaolo Cruz (orgs.). Novas direções na governança da justiça e da segurança. Brasília: Ministério da Justiça, 2006, pp. 455490.

. Justiça Restaurativa e Mediação Penal: o novo modelo de justiça criminal e de gestão do crime. Rio de Janeiro: Lumen Juris, 2007. 
TATE, C. Neal; VALLINDER, Torbjörn (orgs.). The Global Expansion of Judicial Power. New York: New York University Press, 1995.

TÖNNIES, Ferdinand. Comunidade e sociedade (textos selecionados). In: MIRANDA, Orlando de (org.) Para ler Ferdinand Tönnies. São Paulo: EDUSP, 1995 [1887], pp. 231352.

VAN NESS, Daniel; STRONG, Karen Heetderks. Restoring Justice. $2^{\mathrm{a}}$ ed. Cincinnati: Anderson Publishing, 2002.

VIANNA, Luiz Werneck; CARVALHO, Maria Alice Resende de; MELO, Manuel Palacios Cunha; BURGOS, Marcelo Baumann. A judicialização da política e das relações sociais no Brasil. Rio de Janeiro: Revan, 1999.

WALGRAVE, Lode. From community to dominion: in search of social values for restorative justice. In: WEITEKAMP, Elmar G.M.; KERNER, Hans-Jürgen (eds.). Restorative Justice: theoretical foundations. Portland: Willan, 2002, pp. 71-89.

- Imposing restoration instead of inflicting pain. In: HIRSCH, Andrew von; ROBERTS, Julia; BOTTOMS, Anthony E.; ROACH, Kent; SCHIFF, Mara (eds.) Restorative Justice \& Criminal Justice: competing or reconcilable paradigms? Portland: Hart Publishing, 2003, pp. 61-78.

WIEWORKA, Michel. Case studies: history or sociology? In: RAGIN, Charles; BECKER, Howard (orgs.). What is a case: exploring the foundations of social inquiry. Cambridge: Cambridge University Press, 1992, pp. 159-172.

ZAFFARONI, Eugenio Raúl. Em busca das penas perdidas. Rio de Janeiro: Revan, 2001.

ZEHR, Howard. Changing lenses: a new focus for crime and justice. Waterloo: Herald Press, 1995. 


\section{Anexos}

1. Basic principles on the use of restorative justice programmes in criminal matters (ECOSOC);

2. Carta de Araçatuba

3. Carta de Recife

4. Carta de Brasília

5. Relatório de aprovação de Sugestão Legislativa e Projeto de Lei sobre Justiça Restaurativa

6. Questionário de atualização de dados sobre o Projeto-Piloto de Justiça Restaurativa dos Juizados Especiais Criminais do Núcleo Bandeirante-DF 


\section{Economic and Social Council Dist: Grews}

13 Amgut 2002

Original: English

Resolutions and decisions adopted by the Economic and Social Council at its substantive session of $\mathbf{2 0 0 2}$

(1-26 July 2002) 
$2002 / 12$

Basic principles on the use of restorative justice programmes in criminal matters

The Eonwis and Sold Cound,

Ruwling its rowletion 199926 of 28 Jely 1999, qutitlod "Dowlopment azd implamentation of modiation and renteratin jestice moumen in criminal jestice", in which the Council raquats the Comminton on Crime Promotion and Crimins] Jutin to concidar the desinbility of formolating Unitod Nations atandard in the fiald of modiation and renterative justice,

Ruthe slo its molution 2000/4 of $27 \mathrm{July} 2000$, sutitla "Bste

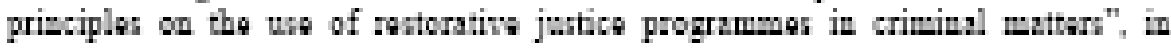

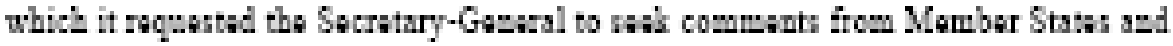


of the Unitod Nations Crims Provention and Criminal Jutica Programme natwork. 


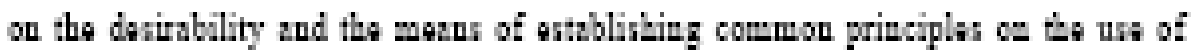
restontive jestice programmes in criminsl mattan, incleding the sdusability of dwoloping a now instrumot for that pupow.

Rakg tho whon the oxirting intarnstional commitmants with reppet to victims, in particular the Declasation of Basic Prizciples of Justice for Vietims of Crime and Abuw of Powas,

Notng the diwnions on rontonative justice durieg the Touth United Mations Cougres on the Praration of Crime and the Trasmant of Offondan, andir the

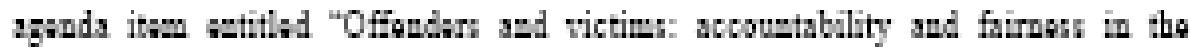
jutike procen",

Thang wat of Gananal Anambly resolution 56261 of 31 Jumary 2002, antitlat "Plyz of action for the implamentation of the Viruna Declaration on Crime

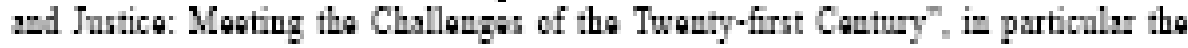

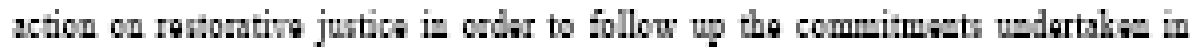
puragreh 28 of the Viome Declaration,

Noing whith appolation the work of the Group of Exports on Rentontive Juthe at thair mating bald in Otsms from 29 Otober to 1 Normabs 2001 ,

Thing wore of the report of the Sowntary-Ganeral on rentonative jertices and the report of the Group of Experts on Restontive Jestice, s

1. Tokes note of the basic prizciples on the us of restorative justice programmen in criminal matters anuexad to the prowet rowhtion;


ratontiw jertice programes in criminal matten in the dovolopment and opantion of rastorative justice programom;

3. Reguats the Sacnary Ganal to anus the widnt ponible

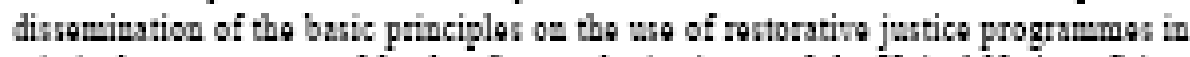
criminal mattors amoeg Member Stater, the iustitutes of the Unitod Natices Crimo Pronetion and Criminal Jutice Prognema natwoth and othor untarnationsl, ragional asd nou-govarumantal organization:

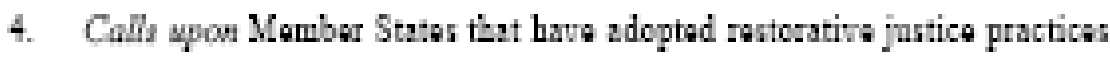
to make information about thone prectices available to other Stats upon requast:

5. Alo coll won Mambar Stater to anist ons asother in the deralopman:


to stimals:e discumion and the axchuge of exp ariones on rostorative jutice;

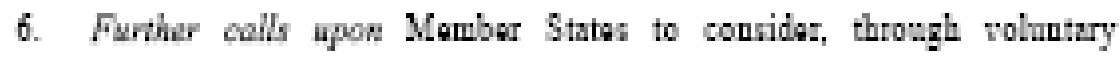



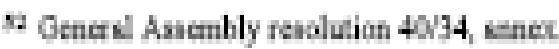

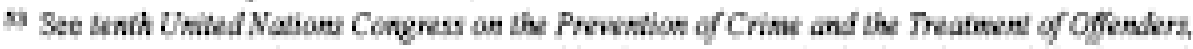

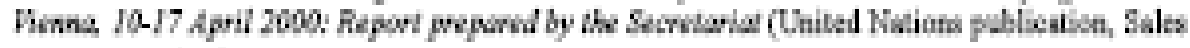

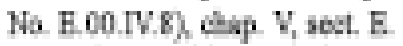

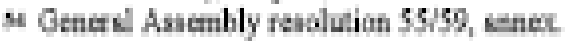

" BCELISTONS and Cor 1 .

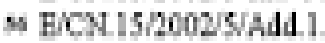




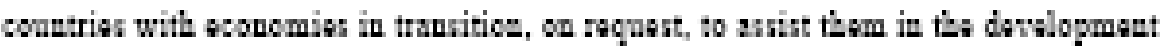
of rentorative juthe programes.

$$
\begin{array}{r}
\text { Sh th plowy wowh } \\
24 \text { Jub 2002 }
\end{array}
$$

\section{Auver}

Basic priaciples on the use of reatorative justice progranes is crimieal marter:

\section{Preamble}

Fuding that thare ha brin, worldwid, a significaut growth of restontive jutica initiativas,

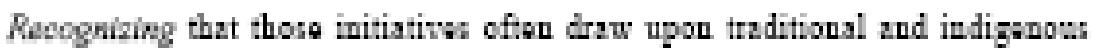
formo of jutice which risw erime sa fundametally barmf:l to poopls,

Emphasiseg that ratontive jutice in an ovolning rapone to crime the:



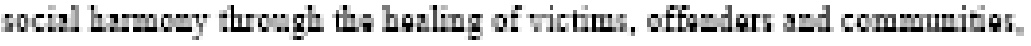

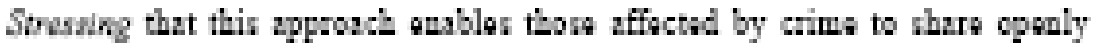
their forling and oxponacen, and aime at adtroning their ends,

Ahew that the approsth providas an opportanity for victims to chtsin repuration, fool nfer and raok clonur; allows offondar to gain insight into the ca:mos and affacts of thoir bohaviour and to take roponsibility in a maningful way;


community wall-baing ad to proven: crime,

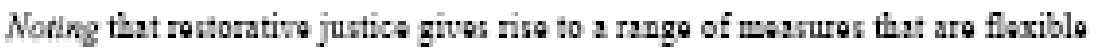

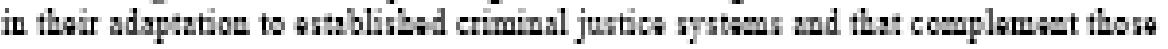
syatems, taling into wcount lagal, social and cultural circumotancos,

Fuconising that the un of rentorative justice doen not projudice the right of Stater to prowente alleged offoudar,

\section{Use of terms}


procesws and raks to achiver rontontive outcomen.

2. "Rostostim precan" moans any procon in which the rictim and the offeder,

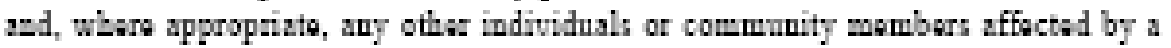

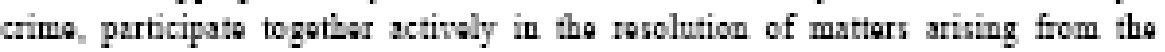

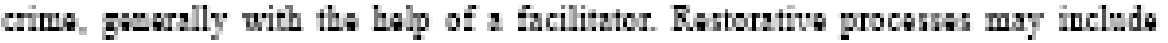
modiation, coucilistion, conforancing and matazing circhs.


procens. Rastorative outcomes inchde responses act progremmer such as

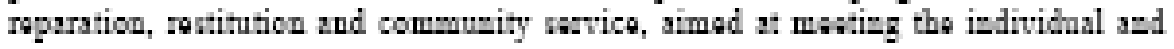

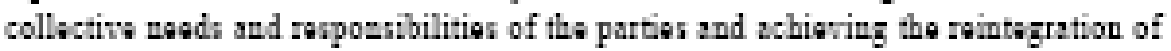
the victim and the offudas. 
4. "Partias" monu the victim, the offestar ad any other indiriduals or community momben affacted by a crima who may be involwd in a rastonative procans.

5. "Facilitator" moun a parwo whore rola is to facilits:a, in a fair and impartial manear, the participstion of the partion in a ratorative procens.

\section{Use of rentorative justice programmes}

6. Ratortiw jutice programman may be mod at ay stage of the crimizs? juthe syom, rubjuct io athousl law.

7. Ratorativ prowas should be used only whare there is maficiant avidance to

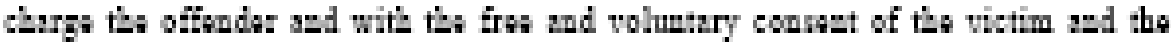
offeder The victim and the offender nould be ablo to withdraw wuch counat at

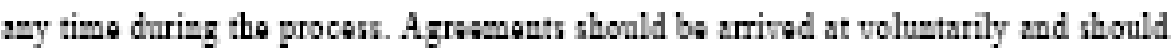
contain only rasonable and proportionz:o obligations.

8. The victim and the offoudar abould nomally agron on the bacic fact of a care w the bais for thair participation in a rentoratine procen. Participation of the

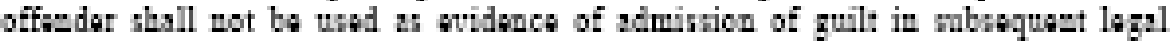
procosdingi.

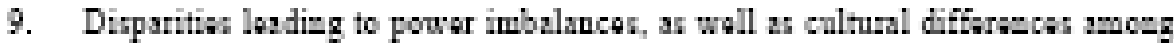
the partios, should be takon into waridastion in rofang a cas to and in cond:eting a ratorative process.


cood:eting a ratorative prosas.

11. Whare restorstive procesen aro not mitable or ponibla, the care should be refarred to the criminal jutice authorition and a dechion should be takn as to how to pronad withest dalny. In such can, criminal jutice officials should sodanow to oucounge the offander to tak responibility vir-t-wis the victim and affected

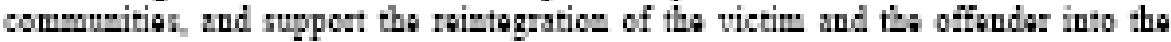
community.

\section{Operation of restorstive justice programmes}

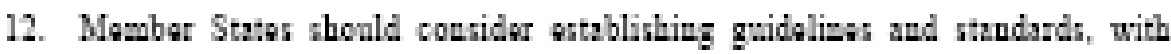

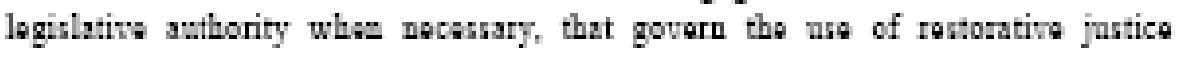

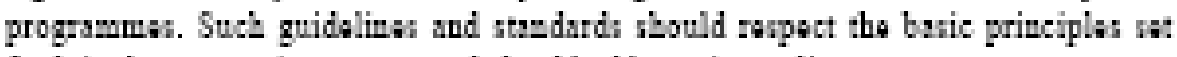
forth in the pronant iustrumant and should addrens, intar slia:

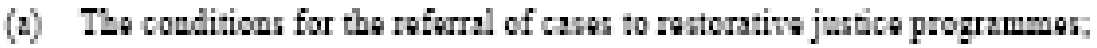

(b) The banding of cars following a rontonatine procan;

(c) The qualificatiour, trining and ansmat of facilitaten;

(d) The administration of rontorative jutios progrmom:

(i) Standards of conpotaces und rula of costuet govorning the epention of ratontiw jertice programmor. 
13. Fundmantal procedusal rafagurds gusantoving faimess to the offodar and

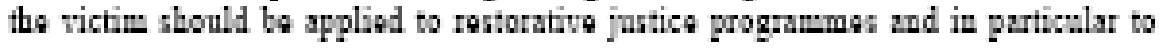
watoritiw procasas:

(2) Subject to ational har, the rictim and the offander sho:ld have the righ:

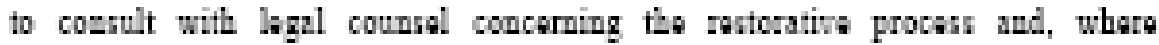

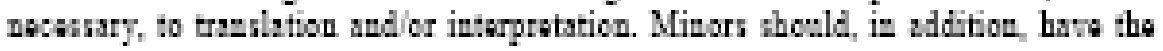
right to the ansitsece of a puset or gundian;

(b) Bofore agraing to participate in restonative procowas, the perties rhould be fully informed of thir rights, the nature of the procen and the powible wonguguear of thair dacision;

(c) Naithas the victim nor the offastar abould be coarced or intucod by

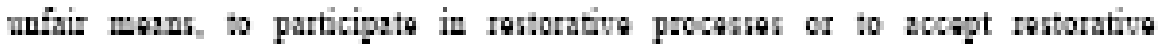
outwin:

14. Dencusions in restorative procenses that wo not conducted in public should be

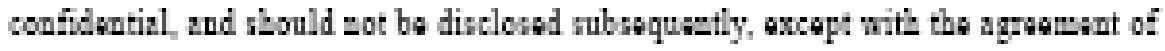
the putien or a ragaired by nationsl has.

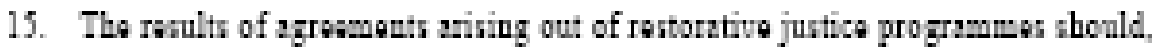
where appopriate, be judicially repervised or iucoponated into jedicial decinions or judgaments. Whare that occers, the outcome sho:ld hame the rame statur as any other judicind dachion or judgement and shesld proclude pronecution in rapact of the nema facts.

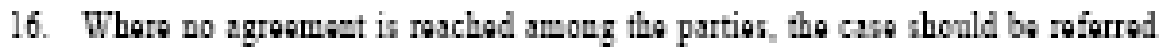
beck to the entablizbed crimiesl jutice procus and a decirion us to bow to procesd

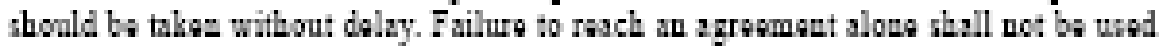
in subequat crimins jentico procudiegs-

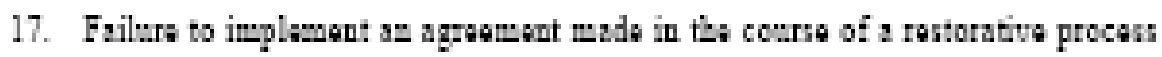

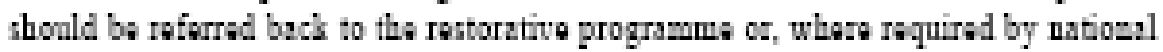
law, to the stablishd criminal jutice procen and a decinion as to bow to proces should be thas withest daluy. Failure to implawent an agroment, other then a

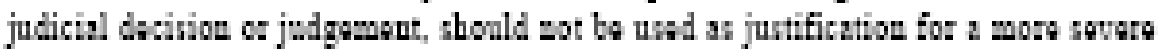

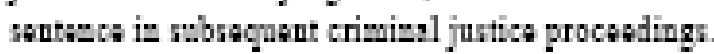

18. Facilitaton should paform thair dutian in an impurtisl manzir, with duo repect to the diguity of the partin. In that capacity, facilinton should oumer that the partia act with reapect toward anch etbar and anabla the partien to fizd a relowat solution among thomsolwas.

19. Facilitator shall poness a good undertaeding of bocal culturen ast communition and, whare appoprista, rocains ivitial trainieg bofore taking op facilitation dutin.

\section{Contionizg developent of restorative justice programose}

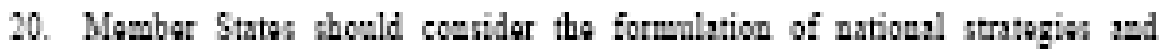
policin aimed at the dmelopmest of rantonative justice and at the promotion of a celture fanousable to the un of ratoratiwe justica among law anforcament, judicis] aed weisl autherition, as wall as local communition 


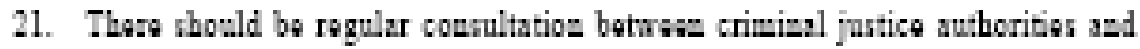
administrators of rentontive jutice progrmenes to dewlog a common

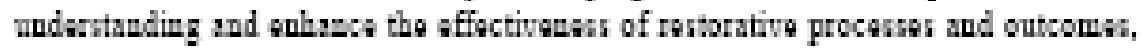

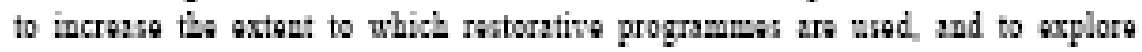

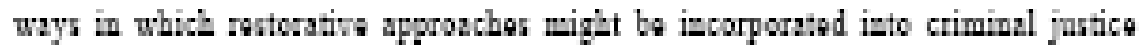
pration.

22. Mambar Staw, in copasation with civil socisy whar approprists, should

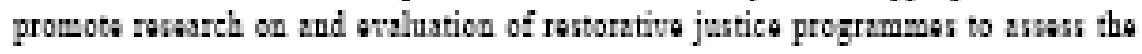

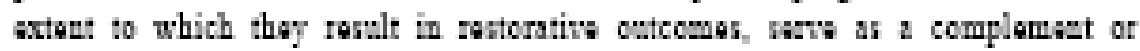




ovar timo. Mambar Stater should tharefore weounge rogular anlustion ast


guido turthar policy and programme dovelopwant.

\section{v. Saviug clause}

23. Nothing in then bavic prizcipla thall affact any right of an offandar or a

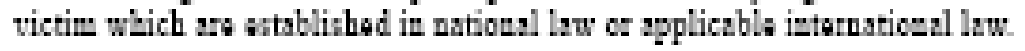




\title{
CARTA DE ARAÇATUBA
}

\section{PRINCÍPIOS DE JUSTIÇA RESTAURATIVA}

\author{
Redação elaborada pelos integrantes do I SIMPÓSIO \\ BRASILEIRO DE JUSTIÇA RESTAURATIVA, realizado na \\ cidade de Araçatuba, estado de São Paulo - Brasil, nos dias 28, 29 \\ e 30 de abril de 2005.
}

Acreditamos que o século XXI pode ser o século da justiça e da paz no planeta, que a violência, as guerras e toda sorte de perturbações à vida humana e ao meio ambiente a que temos estado expostos são fruto de valores e práticas culturais e, como tal, podem ser transformadas. Acreditamos que o poder de mudança está ao alcance de cada pessoa, de cada grupo, de cada instituição que se disponha a respeitar a vida e a dignidade humana.

Acreditamos que o modo violento como se exerce o poder, em todos os campos do relacionamento humano, pode ser pacífico, mudando-se os valores segundo os quais compreendemos e as práticas com as quais fazemos justiça em nossas relações interpessoais e institucionais.

Reformular nossa concepção de justiça é, portanto, uma escolha ética imprescindível na construção de uma sociedade democrática que respeite os direitos humanos e pratique a cultura de paz. Essa nova concepção de justiça está em construção no mundo e propõe que, muito mais que culpabilização, punição e retaliações do passado, passemos a nos preocupar com a restauração das relações pessoais, com a reparação dos danos de todos aqueles que foram afetados, com o presente e com o futuro.

Acreditamos que só desse modo será possível resistir às diversas modalidades de violência que contaminam o mundo sem realimentar sua corrente de propagação. 
Acreditamos que, por isso, será necessário recomendar que cada pessoa, família, comunidade e instituição promovam reflexões e diálogos acerca dos temas da justiça e da paz, em especial acerca das alternativas para implementar valores e práticas restaurativas.

Acreditamos que estas mudanças devem ser paulatinas e que, portanto não podem prescindir do modelo institucional de justiça tal como hoje estabelecido, sobretudo das garantias penais e processuais asseguradas constitucionalmente a todos aqueles que têm contra si acusações de práticas de atos considerados como infracionais.

Acreditamos, ainda, que as práticas restaurativas não implicam uma maximização da área de incidência do direito penal, mas, pelo contrário, uma reformulação do modo como encaramos a resolução dos conflitos.

As práticas restaurativas preconizam um encontro entre a pessoa que causou um dano a outrem e aquela que o sofreu, com a participação eventualmente de pessoas que lhe darão suporte, caso assim o desejarem, inclusive de advogados, assistentes sociais, psicólogos ou profissionais de outras áreas. Pautada pelo entendimento de que o envolvimento da comunidade é fundamental para a restauração das relações de modo não violento, o encontro é a oportunidade dos afetados pelo ato de compartilharem suas experiências e atenderem suas necessidades, procurando chegar a um acordo.

Desta forma, entendemos que as práticas restaurativas que pretendemos passem a fazer parte do modo de consecução da justiça entre nós se norteiem pelos seguintes princípios:

1. plena informação sobre as práticas restaurativas anteriormente à participação e os procedimentos em que se envolverão os participantes;

2. autonomia e voluntariedade para participação das práticas restaurativas, em todas as suas fases;

3. respeito mútuo entre os participantes do encontro;

4. co-responsabilidade ativa dos participantes; 
5. atenção à pessoa que sofreu o dano e atendimento de suas necessidades, com consideração às possibilidades da pessoa que o causou;

6. envolvimento da comunidade pautada pelos princípios da solidariedade e cooperação;

7. atenção às diferenças sócio-econômicas e culturais entre os participantes;

8. atenção às peculiaridades sócio-culturais locais e ao pluralismo cultural;

9. garantia do direito à dignidade dos participantes;

10. promoção de relações equânimes e não hierárquicas;

11. expressão participativa sob a égide do Estado Democrático de Direito;

12. facilitação por pessoa devidamente capacitada em procedimentos restaurativos;

13. observância do princípio da legalidade quanto ao direito material;

14. direito ao sigilo e confidencialidade de todas as informações referentes ao processo restaurativo;

15. integração com a rede de assistência social em todos os níveis da federação;

16. interação com o Sistema de Justiça.

Araçatuba, 30 de abril de 2005 


\section{CARTA DO RECIFE sobre JUSTIÇA RESTAURATIVA}

Redação elaborada por integrantes e aprovada pelos participantes do II SIMPÓSIO BRASILEIRO DE JUSTIÇA RESTAURATIVA, realizado na Cidade do Recife, Estado de Pernambuco - Brasil, nos dias 10, 11 e 12 de abril de 2006.

Acreditamos que:

- a construção de uma sociedade justa, igualitária e pacífica se fará com a participação de todos, no exercício e respeito ao poder pessoal de cada indivíduo em sua relação com o outro;

- a prática de um modelo de justiça que privilegie os valores humanos comuns a todos nós e que focalize o ser humano em todas as suas dimensões é atribuição não só dos que exercem seu mister no âmbito judiciário, mas direito e dever de cidadania de todos nós;

- a Ciência, a Educação e a Cultura podem contribuir para o bem estar e a qualidade de vida justa, como preconizada pela Justiça Restaurativa;

- o exercício de Direitos e Deveres de Cidadania se consolida quando os ideais de humanidade preconizados pela Declaração Universal de Direitos Humanos são considerados e atendidos no âmbito do DIREITO e nas práticas de JUSTIÇA.

Para que essas crenças se concretizem, é necessária a introdução dos Princípios e Práticas da Justiça Restaurativa no nosso sistema de Justiça .

Como estratégia multiplicadora das iniciativas de Justiça Restaurativa em curso, e consolidação desse modelo, recomendamos :

- a difusão e a incorporação de valores restaurativos, mantendo abertura quanto a variações metodológicas e procedimentais, sempre com vistas a potencializar a promoção de resultados restaurativos; 
- que todas as iniciativas de aplicação prática da Justiça Restaurativa sejam transparentes e participativas, e que incluam um componente avaliativo e a divulgação de relatórios de acompanhamento e resultados;

- a ênfase na componente comunitária, em iniciativas de aplicação oficial das práticas restaurativas, e o zelo pelo não dirigismo de qualquer setor institucional;

- a criação de Núcleos e Centros de Estudos em Justiça Restaurativa, abertos à comunidade, nas universidades, nas escolas de ensino médio, nas organizações nãogovernamentais, nas Escolas daMagistratura, do Ministério Público, da Defensoria Pública e da OAB;

- aos poderes públicos federais, estaduais e municipais, especialmente à Secretaria da Reforma do Judiciário do Ministério da Justiça que promova a publicação de subsídios teóricos e práticos,

em português ou traduzidos de outras línguas, incluindo relatórios de acompanhamento, avaliações dos projetos-pilotos e material instrucional para apoio a capacitações;

- à Secretaria da Reforma do Judiciário do Ministério da Justiça a promoção de um Encontro Nacional de Justiça Restaurativa, ainda em 2006, propondo por sede o Supremo Tribunal Federal ou o Superior Tribunal de Justiça, articulando o apoio dos Colégios de Presidentes de Tribunais de Justiça, dos Procuradores-Gerais de Justiça, e dos DefensoresGerais Públicos, das respectivas Corregedorias -Gerais, bem como dos Tribunais e Ministério Público Federais, de modo a viabilizar apoio a participação e respaldo às iniciativas restaurativas de Juízes, Promotores, Procuradores e Defensores Públicos de todo o País;

- a realização do $3^{\circ}$ Simpósio Brasileiro de Justiça Restaurativa em 2007, preferencialmente na Páscoa, tendo por sede a cidade de Natal, RN;

- a difusão e implementação da Justiça Restaurativa, simultânea, articulada e integrada entre suas vertentes institucionais e comunitárias, para gerar sinergia e promover, reciprocamente,

renovação e empoderamento, respeito à horizontalidade, autonomia, isonomia e à diversidade na relação entre as pessoas envolvidas;

- ao Ministério da Justiça o apoio técnico e financeiro à instalação de outros projetospiloto e a delimitação de apoio a estes projetos por um prazo mínimo de cinco anos para 
possibilitar as experiências e o aprendizado necessários à consolidação de uma Cultura de Restauratividade.

Recife, 12 de abril de 2006 


\title{
CARTA DE BRASÍLIA
}

\section{PRINCÍPIOS E VALORES DE JUSTIÇA RESTAURATIVA}

\author{
Documento ratificado pelos painelistas e participantes da \\ Conferência Internacional “Acesso à Justiça por Meios \\ Alternativos de Resolução de Conflitos”, realizada na cidade de \\ Brasília, Distrito Federal, nos dias 14, 15, 16 e 17 de junho de \\ 2005, com base na carta produzida, em abril do corrente ano, no I \\ Simpósio Brasileiro de Justiça Restaurativa, realizado em \\ Araçatuba - SP, em abril de 2005.
}

\section{Considerando que:}

O século XXI pode ser o século da justiça e da paz no planeta, que a violência, as guerras e toda sorte de perturbações à vida humana e ao meio ambiente a que temos estado expostos são fruto de valores e práticas culturais e, como tal, podem ser transformados;

O poder de mudança está ao alcance de cada pessoa, de cada grupo, de cada instituição que se disponha a respeitar a vida e a dignidade humana;

O modo violento como se exerce o poder, em todos os campos do relacionamento humano, pode ser transformado, mudando-se os valores segundo os quais compreendemos e as práticas com as quais concebemos a justiça em nossas relações interpessoais e institucionais;

Reformular nossa concepção de justiça é, portanto, uma escolha ética imprescindível na construção de uma sociedade democrática que respeite os direitos humanos e pratique a cultura de paz;

Essa nova concepção de justiça está em construção no mundo e propõe que, muito mais que culpabilização, punição e retaliações do passado, passemos a nos preocupar com o restabelecimento e a restauração de todas as relações que foram afetadas, em uma perspectiva focada no presente e no futuro;

Só desse modo será possível resistir às diversas modalidades de violência que contaminam o mundo, sem realimentar sua corrente de propagação; 
Será necessário, por isso, recomendar que cada pessoa, família, comunidade e instituição promovam reflexões e diálogos acerca dos temas da justiça e da paz, em especial acerca das alternativas para implementar valores e práticas restaurativas;

Estas mudanças devem ser paulatinas e que, portanto não podem prescindir do modelo institucional de justiça tal como hoje estabelecido, sobretudo das garantias penais e processuais asseguradas constitucionalmente a todos aqueles que têm contra si acusações de práticas de atos considerados como infracionais, bem como a irrestrita observância dos direitos humanos garantidos pela ordem jurídica doméstica e internacional;

As práticas restaurativas não implicam em uma maximização da área de incidência do direito penal, mas, pelo contrário, uma reformulação do modo como encaramos a resolução dos conflitos;

As práticas restaurativas devem ser objeto da construção de uma política pública coordenada capaz de fomentar, fortalecer e difundir as boas experiências e devem ser objeto da reflexão específica diante do atual estágio da democracia na América Latina, devendo incluir necessariamente o poder público, a sociedade civil e organismos Internacionais do sistema global e regional de proteção dos direitos humanos;

As práticas restaurativas preconizam um encontro entre a pessoa que causou um dano a outrem e aquela que o sofreu, com a participação eventualmente de pessoas que lhe darão suporte, caso assim o desejarem, inclusive de advogados, assistentes sociais, psicólogos ou profissionais de outras áreas;

O envolvimento da comunidade é fundamental para a restauração das relações de modo não violento;

O encontro é a oportunidade dos afetados de compartilharem suas experiências e atenderem suas necessidades, procurando chegar a um acordo;

Os painelistas e participantes da Conferência Internacional “Acesso à Justiça por Meios Alternativos de Resolução de Conflitos”, realizada na cidade de Brasília, Distrito Federal, nos dias 14, 15, 16 e 17 de junho de 2005, registram que as práticas restaurativas e respectivas políticas públicas de apoio, devem se nortear pelos seguintes princípios e valores:

1. plenas e precedentes informações sobre as práticas restaurativas e os procedimentos em 
que se envolverão os participantes;

2. autonomia e voluntariedade na participação em práticas restaurativas, em todas as suas fases;

3. respeito mútuo entre os participantes do encontro;

4. co-responsabilidade ativa dos participantes;

5. atenção às pessoas envolvidas no conflito com atendimento às suas necessidades e possibilidades;

6. envolvimento da comunidade, pautada pelos princípios da solidariedade e cooperação;

7. interdisciplinariedade da intervenção;

8. atenção às diferenças e peculiaridades sócio-econômicas e culturais entre os participantes

e a comunidade, com respeito à diversidade;

9. garantia irrestrita dos direitos humanos e do direito à dignidade dos participantes;

10. promoção de relações eqüânimes e não hierárquicas;

11. expressão participativa sob a égide do Estado Democrático de Direito;

12. facilitação feita por pessoas devidamente capacitadas em procedimentos restaurativos;

13. direito ao sigilo e confidencialidade de todas as informações referentes ao processo restaurativo;

14. integração com a rede de políticas sociais em todos os níveis da federação;

15. desenvolvimento de políticas públicas integradas;

16. interação com o sistema de justiça, sem prejuízo do desenvolvimento de práticas com base comunitária;

17. promoção da transformação de padrões culturais e a inserção social das pessoas envolvidas;

18. monitoramento e avaliação contínua das práticas na perspectiva do interesse dos usuários

internos e externos.

Brasília, 17 de junho de 2005. 


\title{
COMISSAO DE LEGISLACARO PARTICIPATIVA
}

\author{
SUGESTAO N* 99, DE 2005
}

\begin{abstract}
Altera dispositivos no Decreto-Lei $\mathbf{n}^{2} 2648$, de 7 de dezembro de 1940, do DecretoLei $n^{\circ} 3669$, de 3 de outubro de 1941 , e da Lei $\pi^{\circ} 9099$, de 26 de setembro de 1995, para facultar o uso de procedimentos de Justica Restaurativa no sistema de justica criminal, em casos de crimes e contravenföes penais.
\end{abstract}

Autor: Instituto de Dreito
Comparado e Intemacional de
Brasila

Relator:Deputado Leonardo Monteiro.

\section{RELATORIO}

Trata-se de sugestão apresentada pelo linstituto de Direito Comparado e Intemacional de Brasilia, que propó alteraçóes no Decreto-Lei $\mathrm{n}^{2}$ 2848, de 7 de dezembro de 1940, do Decreto-Lei n $^{\circ}$ 3689 , de 3 de cutubro de 1941, e da Lei $\mathrm{n}^{2}$ gog9, de 20 de setembro de 1995. para facultar o uso de procedimentos de Justiça Restaurativa no sistema de justga criminal, em casos de crimes e contrawencoes pena's

Em sua justificatva, o autor afirma que a Justiça Restaurativa é um nowo modelo de justica criminal, recomendado pela ONU, dante da evidente necessidade de que a justiga ofereca a resposta ma's adequada para o delito. Destaca que a justiga restaurativa langa um now olhar sobre o crime, para vê-lo como uma vidacáo nas relagbes do infrator oom a vitima e com a comunidade. Implementado já em aguns paises, esse nowo modelo diminuiu os índices de violencia e aumentou a partic pação da comunidade na resolução de seus próprios problemas. 
Assevera que esse nowo modelo de justica criminal, que jả vem dando certo em alguns paises, pode ser um caminho para dimnuir os atos índices de voléncia que assolam a scciedade brasileira.

\section{Eo relatónio.}

Preliminamente, observa-se que, de acordo com a declaragăo prestada pelo ilustre Secretário dessa Comissáb, foram atendidos os requisitos formais previstos no artigo 20 do Regulamento Interno da Comissăo de Legislação Participativa. Passo ao exame do mérito.

Nấ é segredo que o atual modelo de justiç criminal năo tem conseguido atingir de maneira eficaz seus objetiws. Năgo só os indices de violência aumentaram consideravelmente nos úlimos anos, como também a ressocia zaçio dos condenados pela atual justiça criminal tem se revelado uma utopia

O Erasil possui hoje uma das maiores legislaçoes penais do mundo. Temos crime para tudo. Basta forçar um pouco que se encontra um delito ou uma contravençấ. Nos anos noventa, o Congresso Nacional aprovou cerca de cem leis criminais e em boa parte das lés promulgadas tínhamos um aumento de rigor na aploç̧o e execuçâ da sançốo penal. Se aumentar as penas fosse a solugăo para o problema da criminalidade, poderiamos dzer que, hoje, o Brasil seria um paraiso de seguranga e tranqüildade. Apesar disso, quando se fala em justica criminal, nẳo hă como negar uma forte sensaçăo de impunidade e ineficáci.

Diante dessa triste realidade nos traz o autor da sugestấo uma nova proposta para a justiça criminal, a justica restaurativa. Pelo que jă pude estudar sobre o tema, esse modelo de justiça foi criado 
na Nova Zeländia e já funcona também na Austrália, na Inglaterra e no Canadă. Traz, em seu ceme, técnicas especiais para a reparação de todo o dano causado pelo crime no ámbito do infrator, da vitima e da comunidade. Cuida-se da participaçăo efetiva do Estado na tentativa de construir acordo com real capacidade para criar pacificaçäo entre os envolvidos no cenário do delto.

O modelo prevễ encontro entre vítima, infrator e integrantes da comunidade da qual fazem parte. Técnicas de mediagăo sâo usadas por assistentes sociais e psioblogos para mediar a reuniăo 0 paradigma da Justipa restaurativa tem como principio fundamental a voluntariedade: ninguém é obrigado a participar. Os assistentes sociais primeiro conversam con as partes enwolvidas. Se obtiverem respostas. positivas sobre o encontro, agendam a reunäo longe de tribunais ou varas de Justica, de preferéncia em algum local do próprio bairro. Quando há menores envolvidos, săo convidados familares.

Nesse processo, o infrator ouve da vitima e da comunidade como o crime cometido por ele prejudicou a sociedade. Por sua vez, expóe as razóes que o levaram a cometer o delito. Em comum acordo, vtima, infrator e comunidade delmarăo as fomas de punç̧ăo e reparaço do delito. O resultado do encontro entre vítma e infrator é remetido ao juiz, que poderá acatar ou nẩo a definçấo dos envovidos. para puniçọo pelo crime. Se negar, terá de justificar a decisão.

Segundo os defensores desse modelo, a punica do delito, obtida por meio de uma solução negociada na comunidade evita a criagăo de novas ruxas e produz um enorme potencial de pacificacăo social. E um modelo muito inoudor. $Q$ objetivo é diminur a criminalidade por meio, nấ só da puriçăo, mas do restabelecimento dos laços. comunitários.

Diante dos efetos positivos que ja obtiveram os paises que apleam esse novissimo paradigma e do conteúdo eminentemente humanistico da proposta, acredito que será salutar para o País a discussão por essa Casa a respeito do tema, sempre, é claro. 
visando saber se modelos aplcados no exterior também dariam certo no Brasil.

Diante disso, entendo que a proposta trazida pela Sugestão 009 de 2005, é extremamente pertinente e merece ser acatada para o devido trämite legslativo.

Os dema's ajustes na proposta, no que se refere tanto ao mérito, quanto a técrica legislativa, serâo efétwados pelas comissóes competentes.

Por todo exposto, meu voto é pela aprovacio da Sugestão 009 de 2006 na forma do projeto de le apresentado pelo Instituto de Cireto Comparado e Intemacional de Bras ia.

Sala da Comiseäo, em de de 2006.

Deputado Leonardo Monteiro

Relator 


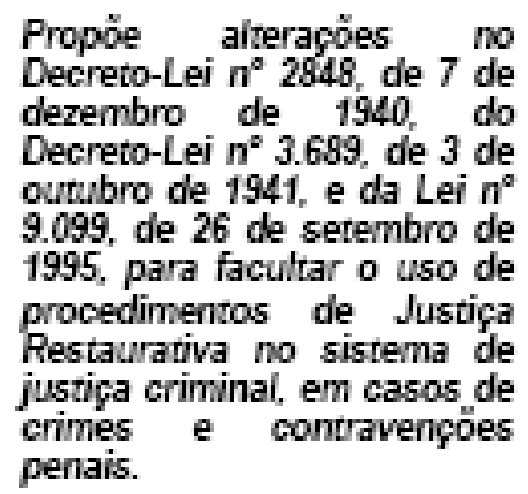

Art $1^{\prime \prime}$ - Esta lei regula o uso facultatiwo e complementar de procedimentos de ustica restaurativa no sstema de justiç criminal, em casos de crimes e contravençbes penais.

Art $2^{\circ}$ - Considera-se procedimento de justica restaurativa o conjunto de práticas e atos conduzidos por facilitadores, compreendendo encontros entre a vitima e o autor do fato deltuoso e, quando apropriado, outras peseoas gu membros da comunidade afetados, que participarăo ooletiva e ativamente na resolugáo dos problemas causados pelo crime ou pela ontravenção, num ambiente estruturado denoninado núveleo de justiga restaurativa.

Art $3^{2}-0$ acondo restaurativo estabelecerá as obrigacoes assumidas pelas partes. objetivando suprir as necessidades indviduais e coletivas das pessoas envolvidas e afetadas pelo crime ou pela contravencăo.

Art $4^{\circ}$ - Quando presentes os requistos do procedimento restauratiw, o juz, com a anuéncia do Mnistéro Público, poderá envar pegas de informacao, temos circunstanciados, inqueritos policiais ou autos de agad penal ao nudeb de justiga restaurativa.

Art $5^{5}$ - O núcleo de justica restaurativa funcionará em local apropriado e com estrutura adequada, contando com recursos materiais e humanos para funconamento eficiente.

Art $\theta^{\circ}$ - O núcleo de justica restauratia será composto por uma coordenacăo adminstrativa, uma cocrdenacâo tecnica interd scip nar e uma equipe de facilitadores. que deverăo atuar de forma ocoperatva e integrada.

$51^{\circ}$. A coordenacão administrativa compete o gerenciamento do nücleo, apciando as atudades da coordenagáo tecnica interdisciplinar.

52 . A coordenacão técnica interdisciplinar, que será integrada por profissionais da area de psicologia e servico social, compete promover a selecäo, a capacitacäo e a avaliagáo dos facilitadores bem como a supervisăo dos procedimentos restaurativos.

53 - Aos facilitadores preferencialmente profssionais das áreas de psicologia e servico social, especiamente capacitados para essa funcao, cumpre preparar e conduzir o procedimento restaurativo.

Art 70 - Cs atos do procedimento restaurativo compreendem: 
a)consultas às partes sobre se querem, voluntariamente, participar do procedimento; bjentrevistas preparatónias com as partes, separadamente;

c)encontros restaurativos objetivando a resoluça dos conflitos que cercam o de to.

Art $g^{\circ}-0$ procedimento restaurativo abrange técnicas de mediacáo pautadas nos principios restaurativos.

Art. $g^{2}$ - Nos procedimentos restaurativos deverâo ser observados os principios da voluntariedade, da dgnidade humana, da imparcalidade, da razoablidade, da proporcionalidade, da cocperacáo, da informalidade, da confidencialidade, da interciscolinariedade, da responsabilidade, do mutuo respeito e da boa-fé.

Parágrafo Único - O principio da confidencialidade visa proteger a intimidade e a vida privada das partes.

Art. 10 - Os programas e os procedimentos restauratios deveräo constituir-se com o apoio de rede sco al de assistencia para encaminhamento das partes, sempre que for necessáro, para vabilzar a reintegracáo socia de todos os envolvidos.

Art. 11 - E acrescentado ao artigo 107, do Decreto-Lé $n^{\circ} 2848$, de 7 de dezembro de 1040,0 incso $X$, com a seguinte redacas:

$X$ - pelo cumprimento efetivo de acordo restauratwo.

Art. 12 - É acrescentado ao artigo 117 , do Decreto-Lei $n^{2} 2848$, de 7 de dezembro de 1940, o incso $\mathrm{VI}$, com a seguinte redaça:

VI - pela homologacão do acordo restauratwo até o seu efetwo cumprimento.

Art 13 - E acrescentado as artigo 10, do Decreto-le n. 3.669 , de 3 de cutubro de 1041, o parágrafo quarto, com a seguinte redaço:

5. $4^{\circ}$ - A autoridade policial poderá sugerir, no relatćrio do inquérito, o encaminhamento das partes a procedimento restauratwo.

Art. 14 - Sân acrescentados ao artigo 24, do Decreto-ei n. 3.669 , de 3 de cutubro de 1041, os parágrafos terceiro e quarto, com a seguinte redacäo:

$53^{\circ}$ - Poderá o juz, com a anuéncia do Mnistério Públoo, encaminhar os autos de inquerito polcial a núcleos de justica restaurativa, quando vitima e infrator manifestarem, voluntariamente, a intenço de se submeterem ao procedimento restaurativo.

$54^{\circ}$ - Poderá o Mnistério Púb oo déxar de propor açáo penal enquanto estiver En curso procedimento restauratio.

Art 15 - Fica introduzido o artigo 99 A no Decreto-lei n. 3699 , de 3 de cutubro de 1941 , com a seguinte redaca:

Art 83 A - O curso da acão pena poderá ser também suspenso quando recomendavel o uso de praticas restaurativas.

Art 16 - Fica introduzido o Capítulo VII, com $\omega$ artgos 566, 567, 568, 569, 560, 561 e 562, no Decreto-le in. 3.689, de 3 de outubro de 1941, com a seguinte redacao: 


\section{VII \\ RESTOCFATO}

Art. 566 - Nos casos em que a personalidade es antecedentes do agente, bem como as circunstáncias e oonsequéncias do crime ou da oontravençäo penal, recomendarem o uso de práticas restaurativas, poderá o juiz, com a anuéncia do Ministério Púbico encaminhar os autos a núcleos de justica restaurativa, para propiciar as partes a faculdade de optarent, woluntariamente, pelo procedimento restaurativo.

Art. 557 - Os núcleos de justica restaurativa serăo integrados por facilitadores, incumbindo-thes ava ar os casos, infomar as partes de forma clara e prec sa sobre o procedimento e ut lizar as técnicas de medacáo que forem necessárias para a rescluça do conflito.

Art. 568 - 0 proced mento restauratiwo consiste no encontro entre a vitima e o autor do fato e, quando apropriado, outras pessoas ou membros da comunidade afetados, que participarăo coletiva e ativamente na resolucăo dos problemas causados pelo crime ou contravenço com auxilio de facilitadores.

Art. 569 - Hawendo acordo e daliberacáo sobre um plano restaurativo, incumbe acs facilitadores, juntamente com os participantes reduzi-lo a temo, fazendo dele constar as responsabilidades assumidas e os programas restauratvos, tais como reparacao restituica e prestacáo de servicos oomunitários, objetivando suprir as necessdades individuais a coletivas das partes. especialmente a reintegracáo da vitima e do autor do fato.

Art 560 - Enquanto näo for homologado pelo juiz o acordo restaurativo, as partes poderáo desistir do processo restaurativo. Em caso de desistenca ou descumprimento do acordo, o juz jugará insubsistente o procedimento restauratiwo e ocordo dele resultante, retomando o processo as seu curso criginal, na forma da le processual.

Art 561 - O faciltador poderá deteminar a imediata suspensáo do procedimento restaurativo quando verificada a impossbilidade de prosseguimento.

Art 562 - 0 acordo estauratiwo deverá necessaniamente servir de base para a decisào jud ọal final.

Parágrafo Unico - Poderá o Juiz dexar de homologar acordo restaurativo firmado sem a observancia dos principios da razoabilidade e da proporcionalidade ou que deixe de atender as necessidades indvicua's ou coletivas dos enwovidos.

Art. 17 - Fica alterado o artigo 62 , da Lei 9.099 , de 26 de setembro de 1996 , que passa a vigorar com a seguinte redaça:

Art 62 - 0 processo orientar-seá pelos critérios da ora idade, simplicidade, infomalidade, economia processua e celeridade, buscando-se, sempre que possive, a concliaçao, a transaço e o uso de práticas restaurativas.

Art 18 - E acrescentado o parágrafo sequndo a artigo 69, da Lei 9.009 , de 26 de setembro de 1906 , com a seguinte redaça: 
S $2^{\circ}-A$ autoridade policial poderá sugerir, no termo circunstanciado, o encaminhamento dos autos para procedimento restaurativo.

Art 19 - É acrescentado o parágrafo sétmo ao artigo 76, da Lei 9.099 , de 26 de setembro de 1905 , com o seguinte teor.

57 - Em qualquer fase do procedimento de que trata esta Lé o Ministério Público poderá oficiar pelo encaminhamento das partes ao núcleo de justica restaurativa.

Art 20 - Esta lé entrará em vigor um ano após a sua pubicacaio.

Deputado Lecnardo Monteiro

Relator 


\section{Questionário de atualização de dados do Projeto-Piloto de Justiça Restaurativa dos Juizados Especiais Criminais do Núcleo Bandeirante-DF ${ }^{39}$}

(janeiro de 2009)

1) Qual o espaço disponibilizado para o programa (Resposta anterior: duas salas para encontros e uma sala para coordenação. Houve alguma alteração?)

Hoje, contamos com três salas para encontros privados ou conjuntos quando o número de participantes não excede a 6 pessoas, uma sala para encontros com um grande número de pessoas e uma sala para equipe técnica e coordenação.

2) Como é formada a equipe? (Resposta anterior: Coordenação Geral (juiz), Grupo Gestor (1 juiz, 3 promotores de justiça, 1 defensor público, 1 assistente social, 2 psicólogas e 1 facilitador) e Equipe Técnica (Supervisão, Coordenação de Execução, Coordenação de Capacitação, facilitadores, apoio administrativo e estagiário), totalizando 33 pessoas. Houve alguma alteração?)

Hoje, a equipe é formada de quatro servidores, duas psicólogas e dois bacharéis em direito e uma estagiária de psicologia, todos lotados na unidade. Contando ainda com a Coordenação Geral composta de: dois Magistrados, três Promotores de Justiça, um Defensor Público. Ainda contamos com alguns dos voluntários para nos ajudar nos atendimentos, mas atualmente estamos atendendo a maioria dos casos com duplas de facilitadores formadas por um Bacharel em Direito e uma Psicóloga. Estamos com a proposta de nova capacitação para formar novos voluntários pronta, dependemos apenas da aprovação da Administração Superior para darmos início à terceira capacitação de voluntários para o Serviço.

3) Qual o vínculo de trabalho dos integrantes da equipe com o programa? (Resposta anterior: facilitadores eram voluntários, coordenação da capacitação era contratada pelo PNUD e demais eram estatutários. Houve alguma alteração?)

39 As respostas foram oferecidas pela própria equipe do Projeto-Piloto. 
Atualmente, o principal vínculo dos integrantes do projeto é o estatuário, dos Operadores do Direito e dos servidores públicos.

4) Quais os critérios para encaminhamento dos casos para o programa? (Resposta anterior: " as infrações penais punidas com até 2 anos de privação de liberdade; critérios: conflitos em que os envolvidos mantêm vínculo ou relacionamento que se projetam para o futuro e em que o conflito permanece e casos em que há necessidade de reparação emocional ou patrimonial”. Houve alguma alteração?)

Os critérios de encaminhamento para o programa têm sido: os crimes de menor potencial ofensivo, cujas partes adversas possuem um relacionamento que se projeta em futuros encontros, com possibilidade de desencadearem novos conflitos.

5) De que maneira os casos são encaminhados? (Resposta anterior: "Inicialmente, os casos era indicados na audiência preliminar, por iniciativa do juiz ou do promotor. Depois, os casos passaram a ser selecionados nas reuniões dos grupo gestor". Houve alguma alteração?)

Retomou-se o modo de encaminhamento via juiz ou promotor durante a audiência preliminar, momento em que as partes confirmam interesse em conhecer o trabalho do Serviço de Justiça Restaurativa. Além disso, atualmente vêm casos não apenas dos Juizados Especiais Criminais do Núcleo Bandeirante, mas também de outros Juizados, como os de Ceilândia e Guará, por exemplo.

6) Quantos casos já foram atendidos? (Resposta anterior: "Atualmente existem 36 processos na Justiça Restaurativa, sendo 4 processos em que houve acordo, 12 que retornaram à Justiça comum e 9 em acompanhamento. Restam 12 para serem distribuídos aos facilitadores". Houve alguma alteração?)

Foram atendidos até o momento 134 casos. Na maioria dos casos houve acordo restaurativo. Entretanto, vários ainda estão em andamento. 
7) Quais tipos de conflitos são mais comuns? (Resposta anterior: "os conflitos mais comuns são perturbação da tranqüilidade, lesões corporais, ameaça, delitos de trânsito”. Houve alguma alteração? Há algum tipo de estatística sobre esse dado?)

Os conflitos mais comuns têm sido lesões corporais (art. $129 \mathrm{CP}$ ), injúria (art. $140 \mathrm{CP}$ ), ameaça (art. $147 \mathrm{CP}$ ), perturbação do sossego (art. 42 LCP) e perturbação da tranqüilidade (art. 65 LCP) .

8) Qual o perfil dos envolvidos? (Resposta anterior: "Há predominância do sexo masculino"; "Há predominância da idade adulta abrangendo dos 20 aos 35 anos"; “percebe-se a predominância de pessoas que residem na Candangolândia e no Riacho Fundo I e II”; "Em relação à faixa salarial, observou-se a predominância de valores entre $\mathrm{R} \$ 500,00$ a $1.000,00$; “A religião predominante é a protestante". Houve alguma alteração? Há algum tipo de estatística sobre esses dados?)

Em virtude da redução do número de voluntários, a coleta dos dados de perfil ficou prejudicada, já que o serviço atualmente tem priorizado o atendimento das partes.

9) Qual o procedimento pelo qual tramitam os casos encaminhados? (Resposta anterior: "indicação $\rightarrow$ consulta restaurativa $\rightarrow$ encontro preparatório $\rightarrow$ encontro restaurativo". Houve alguma alteração?)

Quanto ao procedimento, houve uma alteração os encontros preparatórios são privados (e o número de encontros pode variar muito em duração e freqüência dependendo da parte e do entendimento e intimidade que está possui com a resolução autocompositiva de conflitos), e os encontros restaurativos conjuntos.

10) Está sendo realizada alguma forma de avaliação de resultados, posterior à conclusão do caso?

Estamos priorizando os atendimentos, o que reflete em uma pesquisa sobre os resultados, ou seja, pós-atendimento, deficitária. 